\title{
HARDWICK AND HISTORIOGRAPHY†
}

\author{
William N. Eskridge, Jr.*
}

In this article, originally presented as a David C. Baum Memorial Lecture on Civil Liberties and Civil Rights at the University of Illinois College of Law, Professor William Eskridge critically examines the holding of the United States Supreme Court in Bowers v. Hardwick, where the Court held, in a 5-4 opinion, that "homosexual sodomy" between consenting adults in the home did not enjoy a constitutional protection of privacy and could be criminalized by state statute. Because the Court's opinion critically relied on an originalist interpretation of the Constitution, Professor Eskridge reconstructs the history and jurisprudence of sodomy laws in the United States until the present day. He argues that the Hardwick ruling rested upon an anachronistic treatment of sodomy regulation at the time of the Fifth (1791) or Fourteenth (1868) Amendments. Specifically, the Framers of those amendments could not have understood sodomy laws as regulating oral intercourse (Michael Hardwick's crime) or as focusing on "homosexual sodomy" (the Court's focus). Moreover, the goal of sodomy regulation before this century was to assure that sexual intimacy occur in the context of procreative marriage, an unconstitutional basis for criminal law under the Court's privacy jurisprudence. In short, Professor Eskridge suggests that the Court's analysis of sodomy laws had virtually no connection with the historical understanding of eighteenth or mid-nineteenth century regulators. Rather, the Court's analysis reflected the Justices' own preoccupation with "homosexual sodomy" and their own nervousness about the right of privacy previous Justices had found in the penumbras of the Constitution. The Supreme Court's problematic historiography deepens the normative problems other scholars have identified for Hardwick and illustrates conceptual difficulties with the "original understanding" methodology the Court sometimes deploys in constitutional cases.

$\dagger \quad$ This article was originally presented on November 20,1997, as the first 1997-98 lecture of the David C. Baum Memorial Lectures on Civil Liberties and Civil Rights at the University of Illinois College of Law.

* John A. Garver Professor of Jurisprudence, Yale Law School. B.A. 1973, Davidson College; M.A. 1974, Harvard; J.D. 1978, Yale.

Earlier, and shorter, versions of this article were presented as the Baum Lecture at the University of Illinois College of Law and at a faculty workshop at the Georgetown University Law Center. I particularly appreciate comments I have received from Ian Ayres, Carlos Ball, Jennifer Brown, Peter Byrne, Courtney Howland, Jonathan Katz, Neal Katyal, Sarah Light, Mike Seidman, and Mark Tushnet. 
Michael Bowers, adulterer, ${ }^{1}$ and Michael Hardwick, sodomite, were forever joined as a couple when the latter challenged Georgia's application of its criminal sodomy law to consensual oral sex between two adult men. Hardwick maintained that such application violated the right to privacy the Supreme Court has found in the Due Process Clause. Bowers, then Attorney General of Georgia, defended the law's constitutionality. Hardwick won in the court of appeals, Bowers in the Supreme Court. ${ }^{2}$ Although the Georgia sodomy law prohibited oral and anal intercourse between two people of either sex, Justice Byron White's opinion for a five-Justice majority in Bowers v. Hardwick ruled that the "only claim properly before the Court . . . is Hardwick's challenge to the Georgia statute as applied to consensual homosexual activity." 3 Narrowed in this way, Hardwick's claim was distinguishable from those in earlier cases where the Court had invoked a constitutional right of privacy, for those cases had arisen in the context of procreation and heterosexual intimacy. ${ }^{4}$ Central to the Court's analysis was its belief that the due process right of privacy could only be applied to protect those fundamental liberties "deeply rooted in this Nation's history and tradition." "5 Because homosexual sodomy had long been criminal in Anglo-American law, the Court held that there was no "deeply rooted" liberty Hardwick could claim" and, indeed, that Hardwick's fundamental rights claim was "at best, facetious." The Court then asked whether Georgia had a rational basis for its sodomy law and found such a basis in a "presumed belief of a majority of the electorate in Georgia that homosexual sodomy is immoral and unacceptable" and in "majority sentiments about the morality of homosexuality."8

The Court's decision in Hardwick has become infamous, partly because Justice White went out of his way to focus on and disrespect "homosexual sodomy" and "homosexuality." 9 The focus on homosexuality was also pronounced in Chief Justice Burger's concurring opinion, which relied on "Judeo-Christian moral and ethical standards" and "millennia of moral teaching[s]" to emphasize that "the act of homosexual sodomy" cannot be treated as any kind of fundamental right. ${ }^{10}$ The association of sodomy with homosexuality did not come

1. See Kevin Sack, Georgia Candidate for Governor Admits Adultery and Resigns Commission in Guard, N.Y. TIMEs, June 6, 1997, at A1.

2. See Bowers v. Hardwick, 478 U.S. 186 (1986).

3. Id. at $188 \mathrm{n} .2$.

4. See id. at 190-91 (distinguishing, e.g., Skinner v. Oklahoma, 316 U.S. 535 (1942); Griswold v. Connecticut, 381 U.S. 479 (1965); Roe v. Wade, 410 U.S. 113 (1973)).

5. Hardwick, 478 U.S. at 192 (quoting Moore v. City of E. Cleveland, 431 U.S. 494, 503 (1977) (plurality opinion)).

6. See id. at 194.

7. Id.

8. Id. at 196.

9. See id. at $189-90,195-96$.

10. Id. at 196-97 (Burger, C.J., concurring). 
out of thin air, for it resonated in the popular mind, and by 1986 seven states had made consensual sodomy a crime only for same-sex partners, with three others following this course shortly after Hardwick. ${ }^{11}$ Nonetheless, this kind of rhetoric turned the Hardwick decision into a litmus test for legal homophobia: If you supported the decision, especially if you failed to disclaim the rhetoric, you were signaling antihomosexual feelings, and perhaps also an insecurity about your own sexuality. (It did not help matters that the critical fifth vote for the majority, Justice Lewis Powell, was reported to have switched his vote after intense lobbying from the Chief Justice; Powell himself fueled Hardwick's bad odor when he later proclaimed it the vote he most regretted. ${ }^{12}$ ) Although gay people are predictably critical of the decision, respected academic commentators, most of them nongay, have strongly criticized Hardwick as manipulative, ${ }^{13}$ ignorant and inefficient, ${ }^{14}$ violent, ${ }^{15}$ historically inaccurate,${ }^{16}$ misogynistic, ${ }^{17}$ authoritarian, ${ }^{18}$ and contrary to precedent. ${ }^{19}$ If some of the Justices aimed to disrespect homosexuality, they ended up wounding the Court.

Institutionally, the Court sought to atone for Hardwick in Romer v. Evans, ${ }^{20}$ which invalidated a Colorado initiative preventing state and local government units from carrying out laws or policies whereby "homosexual ... orientation" could be the basis for any positive legal claim. The Court emphasized two features of the initiative, either assertedly fatal to its constitutionality even under the easy-to-pass rational basis standard of review. On the one hand, the initiative, "unprecedented in our jurisprudence," sought to accomplish some-

11. These seven states are Arkansas (1977), Kansas (1969), Kentucky (1974), Missouri (1977), Montana (1973), Nevada (1977), and Texas (1973). Soon to join this array were Oklahoma (judicial decision, 1986), Tennessee (1989), and Maryland (judicial decision, 1990). Nevada repealed its same-sex sodomy misdemeanor in 1993. Courts in Kentucky (1992), Montana (1997), and Tennessee (1996) struck down their laws as violations of state constitutional privacy rights. For precise references, see the Appendix.

12. See Al Kamen, Powell Changed Vote in Sodomy Case, Wash. Post, July 13, 1986, at A1; Ruth Marcus, Powell Regrets Backing Sodomy Law, WAsh. Post, Oct. 26, 1990, at A3; see also John C. Jefrries, JR., Lewis F. Powell, JR. 513-30 (1994) (recounting story of Powell's deliberation, including the statement by Powell that he had never met a "homosexual").

13. See generally Eve Kosofsky Sedgwick, The Epistemology of the Closet (1990); Janet Halley, Reasoning About Sodomy: Act and Identity in and After Bowers v. Hardwick, 79 VA. L. REV. 1721 (1993).

14. See Richard A. Posner, Sex and Reason 341-50 (1992).

15. See Kendall Thomas, Beyond the Privacy Principle, 92 Colum. L. Rev. 1431, 1461 (1992).

16. See Anne B. Goldstein, History, Homosexuality, and Political Values: Searching for the Hidden Determinants of Bowers v. Hardwick, 97 YALE L.J. 1073, 1102-03 (1988).

17. See Sylvia A. Law, Homosexuality and the Social Meanings of Gender, 1988 WIs. L. Rev. 187, 229-31.

18. See Jed Rubenfeld, The Right of Privacy, 102 HaRv. L. Rev. 737, 747 (1989); see also Frank Michelman, Law's Republic, 97 YALE L.J. 1493, 1496 (1987).

19. See Charles Fried, Order and Law-Arguing the Reagan Revolution-A Firsthand Account 81-84 (1991); Laurence Tribe, American Constitutional Law 142231 (2d ed. 1988).

20. 517 U.S. $620(1996)$. 
thing the state could not do, namely, "singl[e] out a certain class of citizens for disfavored legal status or general hardships." 21 On the other hand, "laws of the kind now before us raise the inevitable inference that the disadvantage imposed is born of animosity toward the class of persons affected."22 Evans not only situates the Supreme Court in a more neutral position as regards homosexuality, but calls Hardwick itself into question.

To focus sodomy prohibitions on "homosexual sodomy" alone, as Hardwick suggested and as ten states have expressly done, is to "singl[e] out a certain class of citizens for disfavored legal status" because of popular "animosity toward the class of persons affected." The Hardwick decision itself illustrates how modern prejudice against gay people seizes upon their presumptive commission of sodomy and totalizes their identity around those acts. As popular stereotypes about gay people have been called into question, the components of this regime have been discredited and expressly antihomosexual sodomy laws ought to meet the same fate. Reconceiving Georgia's sodomy law in a manner contrary to the statutory text, Hardwick found a rational basis for Georgia's sodomy law in the "presumed belief of a majority of the electorate in Georgia that homosexual sodomy is immoral and unacceptable." ${ }^{23}$ Evans struck down a law that rested upon the actual, voted-upon belief of a majority of the electorate in Colorado that homosexuals are immoral and equal rights for them unacceptable. ${ }^{24}$ To satisfy Evans, an antihomosexual law requires something more than popular animosity. ${ }^{25}$ It is hard to make such a showing for consensual private intercourse between gay adults such as Michael Hardwick and his partner.

Because Evans involved an unusually targeted denial of rights to gay people as a class, "unprecedented in our jurisprudence," 26 and focused on homosexual status rather than conduct (sodomy), it is inaccurate to say that the decision overrules Hardwick, even implicitly; the Georgia sodomy law did not on its face focus on same-sex sodomy. But the two decisions do not rest easily together in the same logic set. Stigmatizing an entire class of peaceful citizens as criminals because of their private, consensual behavior has a more pronounced effect on gay people than Colorado's antigay initiative probably would have had, and Evans's rhetoric of inclusion suggests a broader reading. Justice Antonin Scalia recognized this in his Evans dissent. "If it is constitutionally permissible for a State to make homosexual conduct criminal [Hardwick], surely it is constitutionally permissible for a

21. Id. at 633 .

22. Id. at 634 .

23. Bowers v. Hardwick, 478 U.S. 186, 196 (1986) (emphasis added).

24. See Evans, 517 U.S. at $622-25$.

25. See id. at 630-34.

26. Id. at 633 . 
State to enact other laws merely disfavoring homosexual conduct," or "merely prohibiting all levels of state government from bestowing special protections upon homosexual conduct [Evans]." 27 The six-Justice Evans majority failed to deny, much less refute, this assertion. Now that Evans has been decided, the assertion can be reversed: If it is constitutionally impermissible for the state to enact laws disfavoring people who engage in "homosexual conduct," then is it not impermissible to penalize the conduct itself?

Once Hardwick's rationalization of sodomy laws as antihomosexual measures falters, the states prohibiting only same-sex sodomy can no longer defend their laws easily, if at all. Indeed, four of the ten states with such discriminations have, since Hardwick, repealed (Nevada) or judicially invalidated (Kentucky, Tennessee, Montana) their same-sex only sodomy laws. ${ }^{28}$ Additionally, states criminalizing all sodomy must defend their laws by reference to heterosexual as well as homosexual sodomy. This, too, would not be easy. If sodomy laws were applied to consensual heterosexual intimacy, they could only be defended by reference to the policy of limiting sex to the context of procreative marriage, a policy the Supreme Court has repeatedly rejected as a justification for invading privacy rights. The right of privacy already assures heterosexuals the right to avoid procreation by contraception when they engage in penile-vaginal intercourse. ${ }^{29}$ It is a modest step further to allow heterosexuals to commit sodomy, which is another way that heterosexuals can enjoy sexual pleasure without risking unwanted pregnancies. At least three-quarters of the straight population, including the President of the United States, have engaged in oral sex (many of them regularly), and almost a fourth have engaged in anal sex. ${ }^{30}$ It would be absurd to brand all these people criminals, yet that is what a neutral regime criminalizing consensual sodomy would do.

The foregoing is the nutshell case for rethinking Hardwick. The remainder of this article considers the matter in greater detail and from the point of view of the original opinion. Justice White's key argument was that privacy rights could only be extended to conduct traditionally left alone, which "sodomy" had not been in AngloAmerican history. ${ }^{31}$ Part I of this article challenges Justice White's

27. Id. at 641 (Scalia, J., dissenting) (emphasis added); accord John Finnis, Law, Morality, and Sexual Orientation, 69 Notre DAme L. Rev. 1049 (1994).

28. 1993 Nev. Stat. 515; Commonwealth v. Wasson, 842 S.W.2d 487 (Ky. 1992); Gryczan v. State, 942 P.2d 112 (Mont. 1997); Campbell v. Sundquist, 926 S.W.2d 250 (Tenn. Ct. App. 1996) (appeal to state supreme court denied).

29. See, e.g., Griswold v. Connecticut, 381 U.S. 479 (1965).

30. See Edward O. Laumann et al., The Social Organization of Sexuality: Sexual Practices in the United States 98-99 tbl.3.6 (1994); see also H.R. Doc. No. 105-310, at 30 (1998) (providing a detailed account of consensual and oral sex between male president and female intern).

31. See Bowers v. Hardwick, 478 U.S. 186, 192-94 (1986). 
methodology as inconsistent with the Court's privacy precedents, which posed the inquiry at a more general level. The focus of the preHardwick privacy precedents was the general assurance of personal liberty to deploy one's body and form relationships, not the specific presence or absence of regulations for particular deployments or relationships in the nineteenth century. The abortion cases, for example, were wrongly decided under Justice White's approach. Moreover, the intimate activities protected by the Court's precedents suggested libertarian or anticommandeering principles just as hostile to the application of sodomy laws to oral sex between consenting adults, as to the application of contraception laws to adults having penile-vaginal sex.

Part II of this article assumes that Justice White's highly particularist inquiry was set at the appropriate level but challenges his historical account. Although sodomy was illegal in most states in 1868, what Michael Hardwick was doing was clearly illegal in no state until 1879. The colonial and state sodomy laws surveyed by Justice White to prove Hardwick's privacy claim "facetious" criminalized only anal intercourse, including different-sex intercourse. The private oral sex Hardwick committed was not sodomy and was not regulated in any state before 1879; oral sex between two men and men and women was regulated by new laws adopted between 1879 and 1921; oral sex between two women was unregulated in most states until the twentieth century. Not only does part II document the Court's error in understanding Hardwick's conduct as historical sodomy, but it shows how anachronistic Justice White was being to attribute "homosexual sodomy" as the regulatory object of nineteenth-century statutes. The focus of sodomy laws was to regulate nonprocreative and possibly nonconsensual insertions of the male penis, not to stigmatize "homosexuality." It was only in this century that sodomy laws have become understood as stigmatizing "homosexual" conduct, including intimacy among women.

Part III of this article ponders the consequences of Justice White's anachronisms. A historiographically sophisticated history of sodomy laws reveals the deep tension between their moralizing regime of compulsory procreation and the precise holdings of the Court's privacy precedents, which make that an impermissible state purpose. The multiple incongruences between Hardwick and historiography not only undermine the authority of that particular precedent but also illustrate difficulties with original understanding methodologies more generally.

\section{Critique of HardwiCK's Analysis of Precedent}

Although "privacy" is not named as a protected right in the U.S. Constitution, American judges since the mid-nineteenth century have read constitutional assurances of "due process of law" to have a sub- 
stantive libertarian component. ${ }^{32}$ In Union Pacific Railroad Co. v. Botsford ${ }^{33}$ for example, the Supreme Court held that the state could not require people to submit to physical examinations. The right to bodily integrity formed the core of the early right to privacy, but the Court saw the right to include intimate associations as well. Summing up prior cases, the Supreme Court in 1923 explained that the "liberty" protected by the Due Process Clause includes "not merely freedom from bodily restraint but also the right of the individual to contract, to engage in any of the common occupations of life, to acquire useful knowledge, to marry, establish a home and bring up children." ${ }^{34}$ This was a traditionalist vision of privacy. Significant in this catalogue of constitutional liberties was the omission of sexual liberty. This omission was underscored by Justice Oliver Wendell Holmes's opinion in Buck v. Bell, ${ }^{35}$ which treated as a routine matter Virginia's forced sterilization of mentally disabled people. Reflecting the ideology of American degeneracy theorists as well as the progressives' disinclination to allow judges to tinker with legislated social engineering, Holmes was pretty satisfied with himself for writing a dismissive opinion. But the next generation of judges was more likely to believe that sexuality is a key feature of one's personal development and, therefore, a liberty as fundamental as family. ${ }^{36}$

Thus, the Court in Skinner $v$. Oklahoma ${ }^{37}$ struck down a sterilization scheme applicable to certain classes of "habitual criminals" (such as thieves) and not others (such as embezzlers). Justice William Douglas's opinion for the Court defended a more skeptical judicial scrutiny of sterilization legislation on the ground that it involves "one of the basic civil rights of man. Marriage and procreation are fundamental to the very existence and survival of the race." 38 The person sterilized "is forever deprived of a basic liberty." 39 Although invoking the Equal Protection Clause, Skinner reflected a broader principle also found in Supreme Court due process decisions protecting against undifferentiated state invasions of rights that are "implicit in the concept of ordered liberty." 40 Most of the due process, ordered-liberty decisions involved the physical freedom implicated in search-and-seizure and

32. See Pierce v. Society of Sisters, 268 U.S. 510, 518-21 (1925); Meyer v. Nebraska, 262 U.S. 390, 391 (1923); Maynard v. Hill, 125 U.S. 190, 205 (1888); Wynehamer v. People, 13 N.Y. $378,486-87$ (N.Y. 1856) (leading case). The history is discussed in Washington v. Glucksberg, 521 U.S. 702, 721-36 (1997) (Souter, J., concurring).

33. 141 U.S. 250 (1891).

34. Meyer, 262 U.S. at 399.

35. 274 U.S. 200 (1927). For background, see Stephen Jay Gould, Carrie Buck's Daughter, 2 Const. Commentary 331 (1985).

36. See William N. Eskridge, Jr. \& Nan D. Hunter, Sexuality, Gender, and the LAw 1-55 (1997) (privacy cases); id. at 136-202 (discourse of sexuality and American law).

37. 316 U.S. 535 (1942).

38. Id. at 541 .

39. Id.

40. Palko v. Connecticut, 302 U.S. 319, 325 (1937). 
other criminal procedure cases, but Margaret Sanger and her allies in the planned parenthood movement insisted that ordered liberty also included the obverse of Skinner: the right to engage in sex without fear of pregnancy. ${ }^{41}$

The Supreme Court twice, on procedural grounds, dismissed planned parenthood lawsuits against Connecticut's 1879 law criminalizing the sale or use of contraceptives. ${ }^{42}$ In the second challenge, Poe v. Ullman, dissenting Justice John Harlan reached the merits and argued that Connecticut's ban violated the Due Process Clause. Synthesizing a century of case law, he stated that the Due Process Clause protects rights " "which are ... fundamental; which belong . . . to the citizens of all free governments," "43 for "the purposes [of securing] which men enter into society." "44 Citing Skinner, Harlan argued that the privacy involved in lovemaking by a married couple in their home involves the most fundamental aspect of "liberty" and requires strict scrutiny ${ }^{45}$ Harlan immediately qualified his argument: "The right of privacy most manifestly is not an absolute. Thus, I would not suggest that adultery, homosexuality, fornication and incest are immune from criminal enquiry, however privately practiced." 46

The Supreme Court finally reached the merits of Connecticut's anticontraception law in Griswold $v$. Connecticut ${ }^{47}$ and struck it down as inconsistent with a right of privacy Justice Douglas cobbled together from the penumbras of rights declared in the Bill of Rights. Griswold not only confirmed Skinner's suggestion that an individual has a fundamental liberty interest in sexual activity, but expanded upon that idea. Whereas Skinner emphasized the traditional goal of procreation when it protected against state sterilization, Griswold necessarily delinked constitutional protection of private sexuality from procreation. Whereas Skinner struck down a eugenics-based statute that was a relative innovation in American law, Griswold struck down an anticontraception law that dated from 1879 and that had been preceded by anticontraception laws at the national, state, and local levels. ${ }^{48}$ Not only had Americans not "traditionally" enjoyed free access to contraceptives, but the Due Process Clause was adopted (in

41. For discussions of Sanger's crusade, see Ellen Chessler, Woman of Valor: Margaret Sanger and the Birth Control Movement in America (1992); Eskridge \& HuNTER, supra note 36 , at 3-19.

42. See Tileston v. Ullman, 318 U.S. 44 (1943) (per curiam); Poe v. Ulman, 367 U.S. 497 (1961).

43. Poe, 367 U.S. at 541 (Harlan, J., dissenting) (quoting Corfield v. Coryell, 6 F. Cas. 546 (C.C.E.D. Pa. 1823)).

44. Id. (quoting Calder v. Bull, 3 Dall. 386, 388, 1 L. Ed. 648 (1798)).

45. See id. at 548 .

46. Id. at 553 .

47. 381 U.S. 479,487 (1965).

48. On the background to anticontraception laws, see Heywood Broun \& Margaret Leech, Anthony Comstock 128-44 (1927); Carroll Smith-Rosenberg, Disorderly ConDUCT: Visions OF GENDER IN VICTORIAN AMERICA (1985). 
1868) against the backdrop of increasing national consensus favoring laws criminalizing the distribution of contraceptives. Hence, Griswold was a dynamic interpretation of the Due Process Clause, which not only protected citizens' general liberty interests but also "incorporated" many of the Bill of Rights and their penumbras and made them applicable against the states.

In other ways, however, Griswold embodied a traditionalist understanding of the right of sexual privacy. As the plaintiffs in that case were married, Douglas's opinion for the Court emphasized the marital features of the new right of privacy, the "bilateral loyalty" and intimacy involved in marriage. ${ }^{49}$ Fully agreeing with but going beyond Douglas's emphasis on marital privacy, concurring Justices distanced the right to marital privacy from adultery and homosexuality, two foci of arguably legitimate state regulation. ${ }^{50}$ Notwithstanding the traditionalist grounding of these opinions, the Court expanded Griswold beyond marital sexuality after Harlan's departure from the Court. In Eisenstadt $v$. Baird, ${ }^{51}$ a closely divided Court struck down a statute preventing unmarried couples from obtaining contraceptives. Justice William Brennan's opinion for the Court emphasized the right of "the individual, married or single, to be free from unwarranted governmental intrusion into matters so fundamentally affecting a person as the decision whether to bear or beget a child."52 The individual's right to sexual privacy was dramatically underscored when the Court, in Roe $v$. Wade ${ }^{53}$ held that an unmarried woman has a fundamental due process liberty interest in the decision whether to bear a child or to obtain an abortion.

In 1977, Justice Brennan stated that "Griswold may no longer be read as holding only that a State may not prohibit a married couple's use of contraceptives," and generally protected "individual autonomy in matters of childbearing." 54 How far beyond "matters of child bearing" did the right of sexual privacy extend? This question remained unanswered in the 1970 s. Potentially relevant was Stanley v. Georgia ${ }^{55}$ which had overturned Stanley's conviction for possessing obscene materials in his home. Justice Thurgood Marshall's opinion for the Court rested upon First Amendment protection for the dissemination of ideas, Griswold's right of sexual privacy, and the Fourth Amendment "right to be let alone" to one's own "thoughts . . . emotions and ... sensations," at least in the "privacy of his own

49. See Griswold, 381 U.S. at $485-86$.

50. See id. at 499 (Goldberg, J., joined by Warren, C.J., and Brennan, J., concurring); id. at 499-502 (Harlan, J., concurring in the judgment). See generally David J. GarRow, LiBerTy and Sexuality: The Right to Privacy and the Making of Roe v. Wade 79-195 (1994).

51. 405 U.S. 438 (1972).

52. Id. at 453.

53. 410 U.S. 113 (1973).

54. Carey v. Population Servs. Int'l, 431 U.S. 678, 687 (1977) (plurality opinion).

55. 394 U.S. 557 (1969). 
home." "56 Justice Marshall essentially suggested that masturbatory fantasies, with pictorial aids, were beyond state interference, especially when they occurred at home. Also potentially relevant was the Court's decision in Moore v. East Cleveland, ${ }^{57}$ which struck down a municipal bar to household cohabitation of loosely related or unrelated persons.

Although the Burger Court repeatedly declined to invalidate state sodomy laws throughout the $1970 s,{ }^{58}$ it did not write a full-scale decision addressing the privacy issues. Commentators of various ideologies read the foregoing precedents to create broad constitutional protection for personal freedom in matters of sexual behavior between consenting adults, ${ }^{59}$ and state judges began to follow suit. In People v. Onofre,${ }^{60}$ the New York Court of Appeals invalidated the state law prohibiting consensual sodomy on federal privacy grounds. The court read Eisenstadt and Stanley to require that Griswold's right of privacy be extended to prevent "government interference with the practice of personal choice in matters of intimate sexual behavior out of view of the public and with no commercial component."61

What were the limits of the sexual privacy right in 1982, when Michael Hardwick challenged Georgia's sodomy law? Consider the following array of sexual activities:

(1) Procreative marital intercourse (implicit in Skinner; nineteenth-century cases) ${ }^{62}$

(2) Nonprocreative contraceptive marital intercourse (Griswold);

(3) Nonprocreative contraceptive nonmarital intercourse (Eisenstadt);

(4) Masturbation in one's bedroom (implicit in Stanley);

(5) Abortion (Roe);

(6) Nonnuclear family living arrangements (Moore);

(7) Intercourse in a secluded automobile (Onofre);

(8) Adultery (not necessarily protected, Poe dissent);

(9) Incest (two adults) (same);

56. Id. at 564 (quoting Olmstead v. United States, 277 U.S. 438 (1928) (Brandeis, J., dissenting)).

57. 431 U.S. 494, 506 (1977). The plurality opinion by Justice Powell rested upon privacy concerns. See id. at 499 . Justice Stevens concurred in the judgment on the basis of a takings analysis. See id. at 521.

58. See, e.g., Doe v. Commonwealth's Attorney, 425 U.S. 901 (1976) (per curiam); Wainright v. Stone, 414 U.S. 21 (1973).

59. See Richard A. Posner, The Uncertain Protection of Privacy by the Supreme Court, 1979 SuP. CT. Rev. 173, 198; Harry H. Wellington, Common Law Rules and Constitutional Double Standards: Some Notes on Adjudication, 83 Y ALE L.J. 221, 296 (1973); see also Robert H. Bork, Neutral Principles and Some First Amendment Problems, 47 InD. L.J. 1, 8-9 (1971) (criticizing the whole line of privacy decisions, precisely because they generally protect "sexual gratification[]" without any generating or limiting constitutional principle).

60. 415 N.E.2d 936 (N.Y. 1980).

61. Id. at 941 .

62. See, e.g., Maynard v. Hill, 125 U.S. 190 (1888). 
(10) Commercial sex (not protected, Onofre);

(11) Intergenerational sex (not protected, implicit in Onofre);

(12) Forcible sex (same).

Where did consensual oral sex between two adult men within the home-the conduct for which Hardwick was charged-fit? Was it like the protected activities in categories (3)-(4), as Onofre held, or more akin to the unprotected activities in categories (8)-(9), as Justice Harlan said in his Poe dissent?

To answer this question, one needs to determine what principle undergirds the cases. One principle that explains the case law array is the Millian idea that the state should leave people alone unless their conduct has third-party effects unrelated to "nosy preferences" (my preference to make you just like me) ${ }^{63}$ Under that principle, Hardwick's behavior falls closest to categories (3) and (4), well within the core area protected by the right to privacy. Category (5), abortion, is potentially less entitled to protection than private, consensual sodomy, because there are more third-party interests usually involved: not just the interest of the fetus (or the state's interest in "potential life"), but also the interests of the putative father and grandparents. In Poe and Griswold, Justice Harlan indicated that adultery, "homosexuality," fornication, and incest might be outside the right to privacy, ${ }^{64}$ but his views (dicta in a dissenting opinion) never commanded a majority of the Court. Under the libertarian principle, adultery (category (8)) and incest (category (9)) might be regulated because of their third-party effects: disruption of the family, violation of marriage vows (adultery), predation against vulnerable minors (the typical incest prosecution). Private sexual intimacy between consenting adults, whether it be fornication or sodomy, could fall within the right of privacy as conceived in the post-Griswold cases. In short, Hardwick's activity, at first glance, fits within the core libertarian features of the Court's privacy precedents. The Model Penal Code and Onofre followed that principle, as did the court of appeals in Hardwick's case. ${ }^{65}$

Other principles might be invoked to explain the Court's array of privacy precedents. Botsford ${ }^{66}$ a leading nineteenth-century case, suggests an anticommandeering reading of privacy: the state cannot commandeer our bodies for its rather than our uses, absent a compelling public-regarding reason. Griswold and Moore extend this idea to our relationships. This approach would defend Griswold (categories (2)

63. See John Stuart Mill, On Liberty, in On Liberty and Other Essays 3, 88-110 (McMillan 1926) (1859); see also POSNER, supra note 14 (discussing pragmatic application of a weak version of Mill to issues of sexual liberty).

64. See supra notes 46,50 and accompanying text

65. See People v. Onofre, 415 N.E.2d 936, 939 (N.Y. 1980); Model Penal Code $§ 207.5$ and commentary at 277-78 (Tentative Draft No. 4, 1955); see also H.L.A. HART, LAw, LiBERTY, AND MORAlity 15 (1963) (discussing 1955 draft of Model Penal Code and commentary at page 277).

66. Union Pac. R.R. v. Botsford, 141 U.S. 250 (1891). 
and (3)) and Roe (category (5)) on the ground that the state has no sufficient reason to justify regulations that impose conditions (pregnancy) upon women's bodies and total identities (motherhood) upon women's lives. ${ }^{67}$ As Jed Rubenfeld argues, such a principle fully applies to Hardwick's case as well, for the state's regulation of "homosexual sodomy" channels certain individuals into a network of social roles that will occupy, even dominate, their lives to a substantial degree. ${ }^{68}$

Adopting a narrower principle to explain the precedents, the Court in Hardwick held that the right of sexual privacy, a right not explicitly listed in the Constitution, should not be extended beyond the "fundamental individual right to decide whether or not to beget or bear a child" (categories (1)-(3), (5)). ${ }^{69}$ This was a more presentable reading of the precedents in 1965 than in 1986, however. ${ }^{70}$ One problem is that the Court had already extended the right of sexual privacy beyond this limit in Stanley (category (4)). Hardwick dismissed Stanley as an inapplicable First Amendment decision, ${ }^{71}$ but Stanley relied explicitly on privacy grounds and relied on no other precedents but Griswold and Fourth Amendment (privacy) cases. ${ }^{72}$ Nor does the characterization account for the cases in which the Court struck down laws prohibiting cohabitation of people of different races and of people not belonging to a nuclear family (category (6)). ${ }^{73}$ Finally, to the extent that Hardwick rested upon denying constitutional protections to "homosexuals" that would be accorded "heterosexuals," its inconsistency with Evans is exacerbated. The Court's apparent response to these difficulties would be that "homosexual sodomy" is more like adultery and incest (categories (8) and (9)) than contraception (categories (2) and (3)) for this reason: Like adultery and incest, "homosexual sodomy" has traditionally been stigmatized and regulated, and not left as a matter of individual liberty in Anglo-American law. ${ }^{74}$ The Court's response, and ultimately the entire opinion, rested upon a principle of regulatory history more than a principle of constitutional logic or policy.

As Justice White told the story, proscriptions against "homosexual sodomy" have "ancient roots" whose viability has only slightly di-

67. See Rubenfeld, supra note 18 , at 788-91.

68. See id. at 799-802.

69. Bowers v. Hardwick, 478 U.S. 186, 190 (1986).

70. See Poe v. Ullman, 367 U.S. 497, 553 (1961) (Harlan, J., dissenting), quoted in Griswold v. Connecticut, 381 U.S. 479, 499 (1965) (Goldberg, J., concurring).

71. See Hardwick, 478 U.S. at 195-96.

72. See Stanley v. Georgia, 394 U.S. 557 (1969).

73. See Moore v. City of E. Cleveland, 431 U.S. 494 (1977) (striking down an ordinance limiting occupancy to "related" persons; plurality opinion relies on privacy right); McLaughlin v. Florida, 379 U.S. 184 (1964) (invalidating law banning different-race couples from cohabiting; majority opinion relies on race discrimination rationale but also emphasizes disruption of cohabitants' privacy).

74. See Hardwick, 478 U.S. at 191-95. 
minished. According to Justice White, what Michael Hardwick didoral sex-was an offense at common law and in all thirteen states at the founding, was illegal in thirty-two of the thirty-seven states when the Fourteenth Amendment was ratified (1868), was illegal in all fifty states until 1961, and remained criminal in twenty-four states and the District of Columbia as of $1986 .^{75}$ Given this pervasive history of state concern, Justice White concluded that it was, "at best, facetious" for Hardwick to claim that the nation's history and tradition supported his right to engage in such conduct. ${ }^{76}$ An initial problem with applying a principle of history to determine the scope of a constitutional right of privacy is that such a methodology would seem to require a different result in Roe $v$. Wade, which overturned an abortion prohibition widely accepted in the Reconstruction era. When the Fourteenth Amendment was adopted in 1868 , thirty-six state or territorial laws limited abortion ${ }^{77}$-not so different from the thirty-two states having sodomy laws at that time (the factual basis for Hardwick's holding). The one historical distinction between Roe and Hardwick is that abortion before quickening was not regulated at common law ${ }^{78}$ while sodomy was. This strikes me as a weak basis for distinguishing Roe from Hardwick, however, and the weakness of the distinction is underscored by the actual history of sodomy regulation in the United States.

\section{A More Accurate History of Sodomy Laws}

Because Justice White's opinion in Hardwick rested ultimately upon historical analysis, the opinion may be tested against historical materials and theories. Anne Goldstein initiated the criticism that Hardwick relied on a flawed historical account of sodomy laws. ${ }^{79}$ This article is a continuation of the project she began. Ironically, a historiographically sophisticated understanding of the "original understanding" of sodomy at the time of the framing of the Fourteenth Amendment undermines Justice White's equation of sodomy with oral sex, consensual intercourse, or homosexuality. To understand just how problematic Justice White's history was, requires a retelling of the history from a perspective that is more fact based and better informed by the enormous historiographical literature.

\section{A. Sodomy Law Before the Homosexual, 1533-1880}

At the behest of Henry VIII, the Reformation Parliament of 1533 temporarily criminalized "the detestable and abominable vice of bug-

75. See id. at 192-94 \& nn.5-7.

76. Id. at 194.

77. See Roe, 410 U.S. 113, 174-77 \& n.1 (1973) (Rehnquist, J., dissenting).

78. See id. at 134-40.

79. See Goldstein, supra note 16 , at 1081-86 \& nn.60-72. 
gery committed with mankind or beast."80 Elizabeth I's second Parliament reenacted the Act of 1533, including its penalty of death for buggery. ${ }^{81}$ These statutes secularized offenses that had traditionally been called "sodomy" and had been regulated by the Roman Catholic Church, which Henry and Elizabeth were renouncing. As applied by the English courts, buggery was understood to include anal intercourse between two men ${ }^{82}$ or between a man and a woman ${ }^{83}$ ("sodomy"), any sexual intercourse between a human male or female and an animal ${ }^{84}$ ("bestiality"), but not oral intercourse between humans ${ }^{85}$ (neither sodomy nor bestiality, nor any other species of buggery). Sexual intercourse between women was not regulated by the Act of 1533 .

The English criminal prohibition of buggery and its punishment as a capital crime were generally applicable in the American colonies-either as a matter of common law or by statutory enactment. ${ }^{86}$ For example, although Virginia did not formally have a buggery law in place, the colony in 1624-25 tried and executed Richard Cornish, a ship's master, for attacking and sodomizing a steward. ${ }^{87}$ Explicitly invoking biblical injunctions, the New England colonies alone considered expanding the coverage of the Act of 1533. The Massachusetts Bay Colony debated but ultimately declined to adopt Reverend John Cotton's 1636 proposal that woman-woman intercourse be included as

80. 25 Hen. 8 ch. 6 (1533) (Eng.). This law was one of the first moves in Henry VIII's campaign to separate England from the Roman Catholic Church.

81. The Act of 1533 was only temporary, enduring until "the last Day of the next Parliament." It was renewed, again temporarily, in 1536 and 1539 and was made perpetual in 1540 , near the end of Henry's reign. The law was modified by Edward VI's Parliament in 1548 but repealed when Queen Mary in 1553 abolished all felonies created since the reign of her father, Henry VIII. Elizabeth's second Parliament reenacted the original Act of 1533, upon a finding that "divers evil disposed persons have been more bold to commit the said most horrible and detestable vice of buggery aforesaid." 5 Eliz. ch. 17 (1562) (Eng.). See generally Francois Lafitte, Homosexuality and the Law, 9 BRIT. J. Delino. 8 (July 1958).

82. See Rex v. Corone, 77 Eng. Rep. 1318 (K.B. 1607) (citing Stafford's case).

83. See Rex v. Wiseman, 92 Eng. Rep. 774, 775 (K.B. 1716) (interpreting "mankind" in Act of 1533 to include women and girls).

84. See Sir Edward Coke, The Third Part of the Institutes of the Laws of EngLAND 58-59 (1644).

85. See Rex v. Jacobs, 168 Eng. Rep. 830 (K.B. 1817) (forcible fellatio by man upon unwilling boy was not within buggery statute).

86. See infra Appendix references for Connecticut, Delaware, Georgia, Maryland, Massachusetts, New Hampshire, New Jersey, New York, North Carolina, Pennsylvania, Rhode Island, South Carolina, and Virginia. On colonial regulation of sodomy, see generally Caroline Bingham, Seventeenth-Century Attitudes Toward Deviant Sex, 1 J. INTERdisc. Hist. 447 (1971); Louis Crompton, Homosexuals and the Death Penalty in Colonial America, 1 J. Homosexuality 277 (1976); Robert Oaks, 'Things Fearful to Name': Sodomy and Buggery in Seventeenth-Century New England, 12 J. Soc. Hist. 268 (1978); Robert Oaks, Perceptions of Homosexuality by Justices of the Peace in Colonial Virginia, in HomosexualrTy and THE Law, at 35 (Donald C. Knutson ed., 1980). Critical primary documents are reproduced in JoNATHAN NED KATZ, GAYl Lesbian Almanac: A New Documentary 66-133 (1993) [hereinafter Katz, Almanac] and Jonathan Ned Katz, Gay American History 11-24 (rev. ed. 1992) (hereinafter Katz, AMERICAN History].

87. See Katz, Almanac, supra note 86, at 69-70; KATZ, American History, supra note 86, at 16-19. The English buggery statute was implicitly recognized as in force. See KATZ, AlmaNAC, supra note 86 , at 68 . 
sodomy. ${ }^{88}$ The New Haven Colony in 1656 prohibited under pain of death men lying with men, women lying with women, masturbation (if aggravating circumstances), and any other "carnall knowledge." 89 Masturbation and women lying with women were dropped as offenses when the New Haven Colony was annexed by Connecticut in $1665 .{ }^{90}$ On the other hand, the authorities in Connecticut and Massachusetts, like those in Virginia, were willing to prosecute men and on at least one occasion women for same-sex lewdness without a specific statutory basis. ${ }^{91}$ Altogether, there are records for perhaps as many as twenty sodomy prosecutions and four executions during the colonial period..$^{92}$

Between independence and 1830, the original thirteen states all adopted laws making buggery or sodomy a serious offense, but most eliminated the death penalty.$^{93}$ None of the early statutes defined what precisely was meant by buggery or sodomy, for this remained "a detestable and abominable sin, amongst Christians not to be named," as Sir Edward Coke put it in $1644 .{ }^{94}$ New states adopted similar laws, usually deploying terminology such as "sodomy, or the crime against nature, with mankind or beast." 95 Most of the early statutes were revised by the middle of the century to criminalize what Coke and Blackstone had termed "the infamous crime against nature."96 (Again, note the shift in terminology.) Courts and commentators in the nineteenth century read the sodomy, buggery, carnal knowledge, and crime against nature statutes-hereinafter collectively described simply as sodomy laws-to criminalize "unnatural" intercourse between men and women as well as men and men, but not between wo-

88. See Katz, Almanac, supra note 86, at 74, 76-78.

89. J. Hammond Trumbull, The True-Blue Laws of Connecticut and New Haven 201 (1879), excerpted in KATZ, AMERICAN History, supra note 86, at 23.

90. See Katz, Almanac, supra note 86, at 85, 94, 102.

91. See, e.g., id. at 75 (Plymouth, 1637; two men prosecuted for "lewd behavior"); id. at 85 86 (Massachusetts Bay, 1642; women prosecuted for "unseemly practices"); id. at 100 (New Haven, 1683; youths prosecuted for "wickedness" with one another).

92. See id. at $29,58,663$, nn.7-8. There may have been fewer than 20 prosecutions for sodomy, as some of the prosecutions listed in Katz were for public lewdness.

93. See infra Appendix references for Connecticut, Delaware, Georgia, Maryland, Massachusetts, New Hampshire, New Jersey, New York, North Carolina, Pennsylvania, Rhode Island, South Carolina, and Virginia. According to Karz, Almanac, supra note 86, Pennsylvania eliminated the death penalty for sodomy or buggery in $1786, \mathrm{id}$. at 130 , followed by New Jersey and New York in 1796, id. at 121, 125; Rhode Island in 1798, id. at 105; Virginia in 1800, id. at 104; Massachusetts in 1805, id. at 122; New Hampshire in 1812, id. at 131; Connecticut in 1821, id. at 677 n.40; Delaware in 1826, id. at 131; North Carolina in 1869, id. at 104; and South Carolina in 1873 , id. at 128.

94. CoKe, supra note 84 , at 58-59.

95. See, e.g., Wis. Rev. Stat. ch. 139, § 15 (1849); see also Ill. Rev. Code, Crim. Code $\S 50(1827)$.

96. Coke, supra note 84, at 58-59; 1 William Blackstone, Commentaries *215 (1765). Examples of such midcentury revisions can be found in DEL. CODE ANN., tit. 20, ch. 131, $\$ 7$ (1852); Mass. Gen. Laws ch. 165, § 18 (1860); N.C. Rev. Code, ch. 34, § 6 (1854). 
men and women. ${ }^{97}$ Although there were only a handful of reported cases (discussed below), sodomy prosecutions occurred episodically throughout the century.

That there was a complex regulatory philosophy underlying Anglo-American sodomy laws is illustrated by one of the earliest American cases, the prosecution of William Plaine of Guilford, in the New Haven Colony. He was prosecuted and executed in 1646 (before New Haven's sodomy statute of 1655) for "unclean practices." Governor John Winthrop of Massachusetts Bay described the case:

[B]eing a married man, he had committed sodomy with two persons in England, and ... he had corrupted a great part of the youth of Guilford by masturbations, which he had committed, and provoked others to the like above a hundred times; and to some who questioned the lawfulness of such filthy practice, he did insinuate seeds of atheism, questioning whether there was a God, etc. The magistrates and elders (so many as were at hand) did all agree that he ought to die, and gave divers reasons from the word of God. And indeed it was horrendum facinus [a dreadful crime], and he a monster in human shape, exceeding all human rules and examples that ever had been heard of, and it tended to the frustrating of the ordinance of marriage and the hindering of the generation of mankind. ${ }^{98}$

Three distinct regulatory agendas can be discerned in this account; each is independently supported by other historical evidence.

\section{Fostering Procreative Sex Within Marriage}

The primary historical justification for penalizing crimes against nature reaches back to the early Christian era and the Middle Ages. ${ }^{99}$ Following the lead of Saint Paul, early church fathers synthesized ideas from Christianity's Jewish heritage and Roman context to create a regime whereby sex and pleasures of the body were considered presumptively suspect-morally valuable only when engaged in for procreative purposes within marriage. The Church's synthesis played a critical role in the systematic natural law philosophy developed in the twelfth and thirteenth centuries by Gratian, Albertus Magnus, and Thomas Aquinas. Under Roman Catholic natural law, fornication,

97. See 2 Joel Prentiss Bishop, Commentaries on the Criminal Law $\S 1028$, at 731 (2d ed. 1859); 2 Joseph Chitty, A Practical Treatise on Criminal Law *47-50 (5th Am. ed. 1847); Robert Desty, A Compendium of American Criminal law 143 (1882); John Wil der May, The Law of Crimes $§ 210$, at 223 (1881).

98. John WiNTHROP, History OF NEW ENGLAND FROM 1630 to 1649, at 324 (James Savage ed., 1853), reprinted in KATZ, AMERICAN History, supra note 86, at 22.

99. The account that follows is taken from BERNADETTE J. Brooten, Love Between Women: Early Christian Responses to Female Homoeroticism (1996), as well as Peter Brown, The Body and Society: Men, Women and Sexual Renunciation in Early Christianity (1988); Michael Goodich, The Unmentionable Vice: Homosexuality in the Later Medieval Period (1979). 
adultery, and same-sex sodomy were sins because they were pleasures of the body that by definition occurred outside the context of marriage; contraception and perhaps abortion, masturbation, and all kinds of sodomy were sins because they were by definition nonprocreative. In this way, same-sex sodomy under a natural law understanding was doubly sinful-the pursuit of bodily pleasure without the redemption of procreative marriage.

Winthrop's account of the Plaine case illustrates the importance of these natural law goals for Protestant theology, notwithstanding its other departures from Catholic theology. In America as in England, bodily pleasure was viewed as a corruption-guilty until proven innocent. Thus, marriage was the norm, and procreation within marriage remained critically important for those largely rural societies with high infant mortality rates. For religious fundamentalists like the New England Puritans, the presumptive sinfulness of bodily pleasure-unredeemed by marriage and procreation-was the overwhelming reason for punishing sodomy. ${ }^{100}$ This rationale retained much force in the eighteenth and nineteenth centuries. When American states systematically codified their criminal laws in the middle and late nineteenth century, most of them included sodomy prohibitions in the same title or chapter as, and in close proximity with, adultery, fornication, blasphemy, and incest (typically termed "crimes against public morals and decency"). ${ }^{101}$

\section{Protection of Vulnerable People Against Nonconsensual Sexual Assault}

A second theme of Winthrop's account of the Plaine case was the way in which a potent aggressor allegedly victimized the local "youth." I read this reference to be a concern for the sexual and bodily integrity of more vulnerable citizens at the hands of an aggressive man. Sodomy in this reading was akin to sexual assault without meaningful consent and thereby was linked with rape (nonconsensual penile-vaginal sex with a woman) and seduction (penile-vaginal sex with a girl under the age of consent). This regulatory policy was best illustrated by the infamous 1631 conviction and execution in England of Lord Castlehaven for abetting a rape upon his wife, sodomizing his servants, and countenancing the debauching of his daughter. ${ }^{102}$

The policy against sexual predation is also illustrated by the legal context of sodomy laws in the United States. Several of the early state

100. See, e.g., the New England antisodomy materials collected in Katz, Almanac, supra note 86 , at 78-84, 86-87, 94-100.

101. See, e.g., Ala. Code $\S \S 3230-3257$ (1852); Haw. Penal Code ch. 13 (1850); Ill. Rev. Stat. ch. 30 (1845); Mass. Gen. Stat. pt. IV, tit. 1, ch. 165 (1860); Mich. Rev. Stat. ch. 158, $\S \S 1-30$ (1846); N.Y. REV. STAT. pt. IV, ch. 1, tit. 5, §§ 8-20 (1881).

102. See The Tryal and Condemnation of Mervin, Lord Audley Earl of CastleHaVen (1699), reprinted in Sodomy Trials 11-39 (Randolph Trumbach ed., 1986). 
criminal codes listed sodomy with other crimes of assault, typically adjacent to rape. ${ }^{103}$ Although sodomy later in the century came to be linked more strongly with moral crimes, the structure of sodomy prosecutions remained formally tied to the structure of rape prosecutions. When adults engaged in consensual sodomy, each was the accomplice of the other. In cases of both rape and sodomy, the states required independent corroboration of the accomplice's testimony that the crime had occurred (including penetration by the male sex organ). ${ }^{104}$ American courts bent that rule in cases where sexual penetration was perpetrated by force (like rape) or against a minor (like seduction); such victims were in most states not accomplices as a matter of law, and so their testimony standing alone could convict of sodomy, or rape, or seduction. ${ }^{105}$ The practical consequence of the accomplicecorroboration rule in sodomy cases was that prosecutions were much more difficult - if not usually impossible - in situations of consensual adult sex. Almost all of the reported sodomy cases in the nineteenth century involved allegations that a man was assaulting a less powerful man, woman, ward, child, or animal. ${ }^{106}$

\section{Social Enforcement of Gender Roles}

A third policy served by sodomy laws was to demonize particular persons or dangerous groups. Winthrop's description of Plaine as a "monster" and his not-at-all gratuitous accusation that Plaine was planting seeds of atheism were typical of his era. Accusations of sodomy were regularly accompanied by charges of heresy and devilry

103. See Act of Dec. 17, 1838, \& 4, 1838 Ark. Acts 121, 122 (sodomy linked with carnal abuses of female children); GA. PENAL CODE fifth div., $\S \S 29-38$ (1816) (maiming, rape, sodomy, assault listed together); Act of Dec. 21, 1864, ch. 3, $\S$ 44-47, 1866 Idaho Laws 298, 305-06 (carnal knowledge of female child, sodomy, assault, and rape listed together); ILl. Criminal Code $\S \S$ 47-52 (1839) (same); NEv. CoMP. Laws ch. LV, §§ 2350-2352 (1873) (rape, crime against nature, assault listed together); Act of Mar. 21, 1801, ch. 58, 1801 N.Y. Laws 97 (rape, crime against nature, burglary, robbery listed together).

104. See Francis Wharton, Treatise on the Criminal Law of the United States 443 (2d ed. 1852).

105. See 1 Francis Wharton, A Treatise on Criminal Law 512 (8th ed. 1880).

106. See Hodges v. State, 19 S.E. 758 (Ga. 1894) (defendant charged with molesting a boy under 14 years of age); Collins v. State, $73 \mathrm{Ga} .76$ (1884) (defendant charged with bestiality); Honselman v. People, 48 N.E. 304 (III. 1897) (defendant police officer charged with oral sex with a 14-year-old boy); Davis v. State, 3 H. \& J. 154, 154 (Md. 1810) (defendant allegedly "with force and arms ... did make an assault . . . beat, wound, and illtreat" a 19-year-old "youth"); Commonwealth v. Snow, 111 Mass. 411 (1873) (defendant charged with seducing a "boy"); State v. Frank, 15 S.W. 330 (Mo. 1891) (defendant charged with intercourse with dog); Territory v. Mahaffey, 3 Mont. 112 (1878) (defendant charged with seducing a 14-year-old boy); Foster v. State, 1 Ohio Cir. Dec. 467 (Ohio Cir. 1886) (three defendants charged with gang raping a fourth man); Prindle v. State, 21 S.W. 360 (Tex. Crim. App. 1893) (defendant charged with having oral sex with a child); Commonwealth v. Thomas, 4 Va. 307 (1812) (defendant charged with having sex with a mare). I read all the nineteenth-century sodomy cases reported in either the West Reporting System or the state reports; the foregoing cases are representative of the larger corpus of cases where the court describes the conduct and parties; see also 2 CHгTTY, supra note 97 , at *4850 (all the "model" buggery or sodomy indictments reprinted by Chitty involved allegations of predation by an older man against a minor boy or girl). 
during the Church's enforcement of sodomy rules in the Middle Ages and the state's enforcement in the early modern period. In eighteenthcentury England and France, however, the sodomite came to be seen as a monster of a different sort-a feminized man. ${ }^{107}$ If the greatest social crime in the Middle Ages (and Puritan New England) was religious heresy, the social crime of the nascent modern era was a failure to live up to the bourgeois conceptions of chastity and manhood. ${ }^{108}$

In the United States, the conceptualization of sodomy along lines of gender role was at best rudimentary until after the Civil War. ${ }^{109}$ And, even then, sodomy enforcement was not limited to gender role maintenance, for the application of sodomy laws was also strongly slanted along lines of race, ethnicity, and class. The U.S. Census Bureau reported in 1880 that sixty-three prisoners were then incarcerated for crimes against nature. ${ }^{110} \mathrm{~A}$ majority (thirty-two) of the prisoners were males of color in the South. A third of the white prisoners were foreign (European) born.

\section{B. New Specifications of the Crime Against Nature and the Discourse of Degeneracy, 1880-1920}

The 1880 s were a boom time for crimes against nature. Where the 1880 Census had identified sixty-three prisoners for this crime, the 1890 Census identified $224,{ }^{111}$ a four-fold increase concentrated in the big-city states of the North, especially New York, Baltimore, San Francisco, Boston, Chicago, and Philadelphia. ${ }^{112}$ Arrests continued their upward trajectory in these cities after 1890, and World War I set new sodomy records, as it thrust thousands of men into homosocial settings in this country as well as abroad. ${ }^{113}$ Notwithstanding these new highs, sodomy arrests remained a tiny portion (less than one per-

107. See Michel Rey, Parisian Homosexuals Create a Lifestyle 1700-1750: The Police Archives, in 'Tis Nature's Fault: Unauthorized Sexuality During the Enlightenment 179, 179-91 (Robert Purks Maccubbin ed., Robert A. Day \& Robert Welch trans., 1987); Randolf Trumbach, Sodomitical Subcultures, Sodomitical Roles, and the Gender Revolution of the Eighteenth Century: The Recent Historiography, in 'Tis NATURE's Fault: UnAuthorized SeX. uality During the EnLightenment, supra, at 109, 109-21. For an additional argument that Christian animus to female-female relations reflected an ideology of rigid gender roles, see generally BROOTEN, supra note 99.

108. For the cumulative nature of these abominations, see the indictments reported in 2 CHITTY, supra note 97 , at $* 48-50$.

109. See William N. Eskridge, Jr., Law and the Construction of the Closet: American Regulation of Same-Sex Intimacy, 1880-1946, 82 Iowa L. REv. 1007, 1011-32 (1997).

110. See Frederick H. Wines, U.S. Dep't of the Interior, Census Office, Report on the Defective, Dependent, and Delinguent Classes of the Population of the United States, as Returned at the Tenth Census (1880), excerpted in Katz, American History, supra note 86 , at 37 .

111. See Frederick H. Wines, U.S. Dep't of the Interior, Census Office, Report on Crime, Pauperism, and Benevolence in the United States at the Eleventh Census: 1890, pt.I, at 18-20 (1896), excerpted in KATZ, AMERICAN History, supra note 86, at 39.

112. See Eskridge, supra note 109, at 1110-11 app. 1 (listing sodomy arrest figures for nine American cities from 1880-1940).

113. See id. 
cent) of total arrests in all cities. ${ }^{114}$ These figures probably reflect an increase in nonconforming sexual activity, but they also reflect a heightened middle-class and state concern for citizens who threatened not only traditional views about marriage and sex, but also entrenched gender roles. Sodomy laws played a role in policing these so-called "degenerates" and were stretched and revised by the police, judges, and legislators.

\section{Urban Perversions (Prostitutes, Passing Women, Fairies)}

The feminist and gay historiographical literature suggests convincing reasons for heightened awareness of nonmarital sex generally and same-sex intimacy in particular. ${ }^{115}$ The reasons start with America's urbanization, which accompanied its post-Civil War industrialization. Urbanization was important, in part because it concentrated in one place large numbers of people with heterogeneous sexual tastes and afforded them many opportunities for satisfying those tastes. This is what happened in America's cities after the Civil War. The main phenomenon, eclipsing all others, was the expansion of prostitution: the streetwalker was supplemented by the bawdy house, where groups of female sex workers could live together and ply their trade to willing customers. The expansion of prostitution was met with an even more pronounced "purity movement" against it. ${ }^{116}$ A related phenomenon involved people who "inverted" gender, namely, crossdressing women who appropriated male sexual and economic roles, and "fairies" or female impersonators who dressed as women and accepted the passive role in sexual intercourse with other men. ${ }^{117}$

Americans had seen cross-dressing men and women before the Civil War. What was new and disturbing in the post-Civil War period was, first, the greater incidence of known and even public cross-gender behavior; second, the formation of communities of gender inverts; and, third, a stronger association of inverted gender roles and inverted sexual tastes. In 1871, a sexual advice manual for men said that "every unnatural lust recorded in the mordant satires of Juvenal, the cynical epigrams of Martial, or the licentious stories of Petronius, is practised, not in rare or exceptional cases, but deliberately and habitually in the

114. See id. at 1017.

115. What follows draws liberally from George Chauncey, Jr., Gay New York: Gender, Urban Culture, and the Making of the Gay Male World, 1890-1940 (1994); E. anthony Rotundo, American Manhood: Transformations in Masculinity from the Revolutionary to the Modern Era (1993); SMITH-Rosenberg, supra note 48; Allan Bérubé, Lesbians and Gay Men in Early San Francisco: Notes Toward a Social History of Lesbians and Gay Men in America (Mar. 27, 1979) (unpublished manuscript for San Francisco Gay History Project, on file with author).

116. See generally Thomas C. Mackey, Red Lights Out: A Legal History of Prostitution, Disorderly Houses, and Vice Districts, 1870-1917 (1987); David J. Pivar, Purity Crusade: Sexual Morality and Social Control, 1868-1900 (1973); Ruth Rosen, The Lost Sisterhood: Prostitution in America, 1900-1918 (1982).

117. See Rosen, supra note 116 , at $84-85$; Rotundo, supra note 115 , at $262-79$. 
great cities of our country." 118 The author described "restaurants frequented by men in women's attire, yielding themselves to indescribable lewdness," as well as "literature so inconceivably devilish as to advocate and extoll this utter depravity." 119 Dr. Frank Lydston in 1889 lectured the Chicago College of Physicians and Surgeons on the extensive "colony of male sexual perverts" in that city, and indeed in "every community of any size." 120 According to the doctor, "they operate in accordance with some definite and concerted plan in quest of subjects wherewith to gratify their abnormal sexual impulses. Often they are characterized by effeminacy of voice, dress, and manner."121 In contrast to men, "women usually fall into perverted sexual habits for the purpose of pandering to the depraved tastes of their patrons rather than from instinctive impulses." $122 \mathrm{He}$ was referring to prostitutes, although he recounted one example of a "woman of perfect physique, who is not a professional prostitute ... who has a fondness for women."123 The most notable phenomenon, Dr. Lydston noted, was the proliferation of bawdy houses "whose principal business is to cater to the perverted sexual tastes of a numerous class of patrons,"124 probably including oral sex that their wives would not provide at home. Communities of gender-benders were prominent and alarming to the denizens of Boston, Chicago, Philadelphia, New York, San Francisco, and other large American cities. ${ }^{125}$

\section{The New Discourse of Inversion and Degeneracy}

At the same time the nation was becoming mildly alarmed by the increasing visibility of people violating established gender norms, a new secularized vocabulary was being developed to understand these people. ${ }^{126}$ Rather than criticizing prostitutes and sodomites for unnatural conduct that violated a natural law or religious ideal, as John

118. George H. Napheys, The Transmission of Life: Counsels on the Nature and Hygiene of the Masculine Function 29 (1880).

119. Id.

120. G. Frank Lydston, Clinical Lecture: Sexual Perversion, Satyriasis and Nymphomania, 61 Med. \& Surgical Rep. 253, 254 (1889), excerpted in Katz, Almanac, supra note 86, at 213.

121. Id.

122. Id.

123. Id.

124. Id. at 256, excerpted in Katz, Almanac, supra note 86, at 214.

125. See generally 2 Havelock Ellis, Studies in the Psychology of Sex: Sexual In. version 351-52 (3d ed. 1915). For particular cities, see ChAUNCEY, supra note 115 (New York); The History Project, Improper Bostonians 38-141 (1998); and Susan Stryker \& Jim Van Buskirk, Gay by the Bay: A History of Queer Culture in the San Francisco Bay Area (1996).

126. The most educational account is Nathan G. Hale, Jr., Freud and the Americans: The Beginnings of Psychoanalysis in the United States, 1876-1917, ch. 4 (1971). Other useful works include Vern L. Bullough, SCIEnce in the Bedroom (1994); Lillian Faderman, SurPassing tHe Love of Men (1981); George Chauncey, Jr., From Sexual Inversion to Homosexuality: Medicine and the Changing Conceptualization of Female Deviance, SALMAGUNDI, Fall 1982-Winter 1983, at 114. Many primary sources are reproduced in KATZ, Almanac, supra note 86. 
Winthrop had done in his description of the Plaine case above, the new "sexologists" and their politically progressive allies criticized prostitutes and androgynes for their gender status that represented a degeneration (downward evolution) from normal gender identities and threatened the health of a dynamic society. This emphasis on degenerate status as opposed to unnatural conduct reflected a shift in thinking about same-sex intimacy.

The most influential early sexologist was Richard von Krafft-Ebing, whose Psychopathia Sexualis was first published in 1886 and updated periodically. ${ }^{127} \mathrm{He}$ started with biologically gendered assumptions about men's and women's different sexual instincts: Man "has beyond doubt the stronger sexual appetite" and is "aggressive and impetuous," while nurturing woman "remains passive" as the man woos her. ${ }^{128} \mathrm{He}$ posited a set of profound gender differences and linked them to racial eugenics. "The higher the anthropological development of the race, the stronger these contrasts between man and woman, and vice versa." ${ }^{129}$ Krafft-Ebing's book took for granted that normal healthy sex is penile-vaginal intercourse between a masculine male and a feminine female and then systematically categorized an array of deviations from this norm, all of them rooted in a congenital defect in the deviant's brain or constitution. "Inversion" by women or men revealing physical or psychological characteristics of the opposite sex was for Krafft-Ebing a leading sexual pathology reflecting a broader mental or physical "degeneration," or reversion to a prior evolutionary status. ${ }^{130}$

American doctors found Psychopathia Sexualis intellectually congenial with their own opinions about gender-bending women and men. Reflecting the views of many colleagues who had done case studies, Dr. George Beard wrote in 1884 that when one's sex is perverted, "they hate the opposite sex, and love their own; men become women, and women men, in their tastes, conduct, character, feelings and behavior." 131 The Americans were most fascinated with Krafft-

127. Ernest van den Haag, Introduction to Richard von KRAFFT-EbING, Psychopathia Sexualis: A Medico-Forensic Study 7 (Harry E. Wedeck trans., G.P. Putnams Sons 1965) (1892) [hereinafter KraffT-EbING]. Psychopathia Sexualis was translated and published in English in 1892.

128. Id. at 33.

129. Id. at 56.

130. See id. at 55. A kinder, gentler theory of inversion, more readily accessible to American doctors, was Ellis, supra note 125.

131. George M. Beard, Sexual Neurasthenia: Its Hygiene, Causes, Symptoms, and TREATMENT 106-07 (1884), excerpted in KATZ, AlmanaC, supra note 86, at 200. For other early examples, see James G. Kiernan, Sexual Perversion and the Whitechapel Murders, 4 MEd. STANDARD 170 (1888), paraphrased in KATZ, AlmanaC, supra note 86, at 208; Phillip Leidy \& Charles K. Mills, Reports of Cases of Insanity from the Insane Department of the Philadelphia Hospital, 13 J. Nervous \& Mental Disease 712 (1886); George F. Shrady, Perverted Sexual Instinct, 26 Med. Rec. 70 (1884); P.M. Wise, Case of Sexual Perversion, 4 Alienist \& NeuroloGIST 87 (1883) (case study of woman passing as a man who grabbed a female attendant in a "lewd manner"). 
Ebing's idea that any departure from strict binary gender roles (man=masculine, woman=feminine) represented a degeneration to more primitive forms. Lydston argued that all vice and crime could be traced to "the degenerate classes," those "persons of low grade of development, physically and mentally, with a defective understanding of their true relations to the social system in which they live.... In them, vice, crime, and disease go hand in hand." 132 Prostitutes (with inordinate sexual desire) and sexual inverts (with inappropriate sex and gender roles) were two of the chief degenerate classes, and they contributed in urban areas to a dramatic surge in "perverted" sexual practices. ${ }^{133}$ Lydston believed in evolutionary reversion, whereby the prostitute and invert abandon the inhibitions of civilization and revert to subhuman, animalistic desires. ${ }^{134}$ More alarmingly, degeneracy was thought to be a social disease that could be passed on to the next generation, both through heritable characteristics and the bad example set by degenerates to the young. ${ }^{135}$ Lydston and others of his era proposed bans on marriage by degenerates, eugenic castration, and sterilization as cures. ${ }^{136}$

The Americans' explication and elaboration of Krafft-Ebing was racist as well as moralist. In an 1892 article, Dr. Irving Rosse associated sexual perversions with prehistoric "troglodytes," barnyard animals, prostitutes, and people of color. ${ }^{137}$ His main contemporary example of perversion involved a "band of negro men" of "androgynous character" whose "rites" of phallic worship were raided by the Washington police; he also cited to arrests, mainly of blacks, in Lafayette Park, a notorious cruising ground in the shadow of the White House. ${ }^{138}$ Lydston's book on social disease devoted an entire chapter to the so-called degenerated practices of racial minorities and primitive cultures. "Physical and moral degeneracy-the latter involving chiefly the higher and more frequently acquired attributes-with a distinct tendency to reversion of type, is evident in the Southern negro. This physical and moral degeneracy and atavism is especially manifest in the direction of sexual proclivities," Lydston wrote. ${ }^{139}$ "The removal by his liberation of certain inhibitions placed upon the negro by slavery itself . . . has been especially effective as a causal factor of sexual crimes among the blacks of the South."140

132. G. Frank Lydston, The Diseases of Society (The Vice and Crime Problem) 37 (1904).

133. See id. at 308-09, 372-73.

134. See id. at 90.

135. See id. at $68-70$.

136. See id. at $420-21$.

137. See Irving C. Rosse, Sexual Hypochondriasis and Perversion of the Genesic [sic] Instinct, 17 J. Nervous \& Mental Disease 795 (1892), excerpted in Katz, Almanac, supra note 86 , at 232.

138. Id. at 802, 807, excerpted in KATZ, Almanac, supra note 86, at 233-34.

139. LyDSTON, supra note 132, at 394.

140. Id. 
In the late nineteenth and early twentieth centuries, it was widely believed that the fabric of society and the body politick were threatened by degenerate classes in general, and prostitutes in particular. Committees of citizens banding together to study and eliminate prostitution found surprising evidence of sexual inversion as well. Chicago's Vice Commission, for example, reported vaudeville performances at bawdy houses where men impersonated women and solicited men for "pervert[ed] practices." ${ }^{41}$ New York City's Committee of Fourteen, organized in 1905 to suppress prostitution, uncovered and reported bawdy houses where men solicited other men, ${ }^{142}$ and by 1921 the Committee dedicated itself to suppressing degeneracy as well. Such findings were by no means limited to big cities. The Lancaster, Pennsylvania vice commission reported "[c]onsiderable evidence (impossible to print) of the practice of perversion in Lancaster by inmates of [bawdy] houses, by street walkers, by charity girls, and by men perverts or 'fairies,' and degenerates." 143

The citizen reformers vented an outrage far more intense than the concerns raised by ivory tower sexologists. Anthony Comstock, the antiprostitution crusader who founded the New York Society for the Prevention of Vice, reportedly had this to say about androgynes when he read the autobiography of one:

These inverts are not fit to live with the rest of mankind. They ought to have branded in their foreheads the word "Unclean," and as the lepers of old, they ought to cry "Unclean! Unclean!" as they go about, and instead of the [crime against nature] law making twenty years imprisonment the penalty for their crime, it ought to be imprisonment for life. ${ }^{144}$

Comstock captured a central theme of popular prejudice: Inverts, like prostitutes, did more than commit bad acts; like lepers, they were a status group defined by their disease as much as by their actions. His Society in the 1910s assisted the New York police in apprehending male degenerates by spying on public toilets, male bawdy houses, and dance halls and saloons where sexual inverts socialized. ${ }^{145}$

141. Vice Comm'n of Chicago, The Social Evil in Chicago: A Study of Existing CONDITIONS, WITH RECOMMENDATIONS 139 (1911). Similar connections are in HarTford Vice Comm'n, Report of tHe Hartford Vice Commission 37 (1913); Vice Comm'N Of Philadelphia, A Report of Existing Conditions, with Recommendations 5 (1913).

142. See F.H. Whitin, Sexual Perversion Cases in New York City Courts, 1916-1921, Bulletin $\# 1480$ of the Comm. of Fourteen (New York City 1921), excerpted in Eskridge, supra note 109 , at 1044 .

143. Lancaster (Pa) Citizens Comm'n, A Report on Vice Conditions in the City of LANCASTER, PA. 44 (1913).

144. Earl Lind, Autobiography of AN ANDrogyne 24-25 (1918) (quoting Comstock's alleged reaction to Lind's autobiography).

145. See Whitin, supra note 142, excerpted in Eskridge, supra note 109, at 1044. 


\section{New Specifications of the Crime Against Nature}

In light of the developments detailed above, the early nineteenth century's "unmentionable" crime against nature provoked increased public mention in the last quarter of the century. The classic sodomy scenario (the powerful man forcing anal intercourse upon a weaker victim) gave way to a broader ambit for the crime against nature, which came to be applied against a larger array of gender-benders.

It appears, for example, that sodomy laws were for the first time applied against women, probably prostitutes for the most part. The Census reported only one woman incarcerated for sodomy or the crime against nature in $1880 .{ }^{146}$ That changed in the next generation. ${ }^{147}$ New York City's arrest records regularly reveal female perpetrators of sodomy after 1900; thirty-one of the 601 persons arrested between 1901 and 1910 were women, as were eighteen of 914 arrested between 1911 and 1920; thirty-two of 1142 arrested between 1921 and 1930; and twenty-four of 1446 arrested between 1931 and $1940 .{ }^{148}$ In Baltimore, women were not regularly arrested for sodomy until the state created a new crime of "unnatural lascivious acts" in 1916. From 1917 through 1945 an average of one or two women were arrested each year. ${ }^{149}$ Although these numbers remain tiny compared with those for men and boys, they are a remarkable turning point in the history of sodomy, which had traditionally been a crime only men could commit.

Relatedly and most importantly, attention turned from anal to oral sex. The man sodomizing another man, youth, or woman was supplemented with and indeed supplanted by examples of oral sex-men fellating men or youths, women fellating men, men engaging in cunnilingus with women, and (much later) women engaging in cunnilingus with women. Anglo-American law started to regulate oral sex in the late nineteenth century. In 1817, English courts held oral sex not to be covered by the Act of $1533 .{ }^{150}$ Sixty-eight years later, Parliament responded with the Labouchere Amendment to the Criminal Law Amendments Act of 1885 , an act mainly concerned with prostitution and brothels. Section 11 of the Amendment provided:

Any male person who, in public or private, commits, or is a party to the commission of, or procures or attempts to procure the commission by any male person of, any act of gross indecency 37.

146. See WINES, supra note 110 , excerpted in KATZ, AMERICAN History, supra note 86, at

147. In addition to the material in text, see generally Nicole HaHN RAFTER, PARTIAL JUSTice: Women, Prisons, and Social Control (2d ed. 1990).

148. The figures in text are compiled by the author from the annual police reports for New York City (sources on file with author).

149. The figures in text are compiled by the author from the annual police reports for Baltimore (sources on file with author).

150. See Rex v. Jacobs, 168 Eng. Rep. 830 (K.B. 1817). 
with another male person, shall be guilty of a misdemeanor, and being convicted thereof shall be liable at the discretion of the court to be imprisoned for any term not exceeding two years, with or without hard labour. ${ }^{151}$

The Labouchere Amendment created a new crime which was not limited by the common law to anal sex alone, and unlike prior lewdness or obscenity laws it applied to private as well as public activities. The lesser penalty for the oral sex entailed by "gross indecency" suggested a new focus on consensual, rather than rape-like, intimacy contrary to nature. Finally, the Labouchere Amendment was significant because it is the law that snared Oscar Wilde in 1895. His trials for gross indecency were publicized in the United States as well as England. ${ }^{152}$

American judges and commentators in the mid-nineteenth century followed, with no published exception, the rule of the 1817 English case, that oral sex was not sodomy or buggery or the crime against nature. ${ }^{153}$ Pennsylvania was the first state in this country to respond formally to the unease respectable society felt with new communities of inverts socialized around practices not regulated by old-fashioned sodomy statutes. In 1879, six years before England adopted the Labouchere Amendment, Pennsylvania enacted the first detailed statutory specification in the Anglo-American legisprudence of what "sodomy" might be:

[T] he terms sodomy and buggery . . . shall be understood to be a carnal copulation by human beings with each other against nature res veneria in ano, or with a beast, and shall be taken to cover and include the act or acts where any person shall wilfully and wickedly have carnal knowledge, in a manner against nature, of any other person, by penetrating the mouth of such person; and any person who shall wickedly suffer or permit any other person to wickedly and indecently penetrate, in a manner against nature, his or her mouth, by carnal intercourse, he, she and every such person, committing any of the acts aforesaid or suffering the same

151. Criminal Law Amendment Act, 1885, 48 \& 49 Vict., ch. 69, § 11 (Eng.). The legislative background, and Labouchere's own murky motives, are discussed in F.B. Smith, Labouchere's Amendment to the Criminal Law Amendment Bill, 17 Hist. STUd. 165 (1976).

152. Wilde was a noted author and playwright (including the homoerotic The Picture of Dorian Gray), an ultrafashionable dandy, and an invert (also the father of two children) with the wickedest tongue in England. The pugilistic Marquess of Queensbury accused Wilde of posing as a sodomite. Wilde sued the Marquess for libel in March 1895. Queensbury's lawyers, however, had the names of several young men Wilde had solicited to commit sexual acts for pay. The judge threw out Wilde's lawsuit, and the police arrested him on charges of sodomy (anal sex) and gross indecency (oral sex). Wilde's two criminal trials in April and May 1895 were an international sensation. Newspapers in the United States as well as England reported the testimony of male prostitutes from whom Wilde had apparently solicited sex, of the chambermaids who corroborated their acquaintance with the defendant and the mess their lovemaking left in bed, and of Wilde himself. See Richard Ellmann, Oscar Wilde 435-80 (1st Am. ed. 1988).

153. See 2 Bishop, supra note 97 , at 731; WhARTON, supra note 104, at 443; 1 Wharton, supra note 105 , at 512. 
to be committed as aforesaid, shall be guilty of the crime of sodomy or buggery . . . ${ }^{154}$

The Pennsylvania statute was an ambitious response, including women as well as men and the receiver as well as giver of oral sex. Following the Pennsylvania approach of specifying the crime against nature more precisely within state sodomy laws to include oral sex, were New York (1886), Ohio (1889), Wyoming (1890), Louisiana (1896), Wisconsin (1897), Iowa (1902), Washington (1909), Missouri (1911), Oregon (1913), Nebraska (1913), North Dakota (1913), Alaska (1915), Virginia (1916), Minnesota (1921), Utah (1923), and West Virginia (1931). ${ }^{155}$ Following the English approach of creating a separate crime for oral sex, other states adopted laws prohibiting "gross indecency" (Michigan (1903), ${ }^{156}$ whose statute copied Labouchere's Amendment) or "unnatural and lascivious act[s]" (Massachusetts (1887), ${ }^{157}$ New Hampshire (1899), ${ }^{158}$ Maryland (1916), ${ }^{159}$ Arizona (1917), ${ }^{160}$ Florida $(1917)^{161}$ ) or "carnal indecency" (New Jersey $\left.(1906)^{162}\right)$, or, most directly, "fellatio and cunnilingus" and "oral copulation" (California $(1915,1921)^{163}$ ). By 1923, about half of the American state legislatures had enacted statutes making oral sex a new criminal felony.

In states where the legislature was slow to act, police sought to expand their vague crime against nature laws to include oral sex. At first, they were unsuccessful. The leading case was the Texas Court of Criminal Appeals' 1893 decision in Prindle v. State. ${ }^{164}$ The Texas statute prohibited "the abominable and detestable crime against nature." 165 With no definition of the term, the court felt constrained to

154. Act of June $11,1879,1879 \mathrm{~Pa}$. Laws 148 .

155. See Act of Apr. 26, 1915, ch. 22, 1915 Alaska Laws 50; Act of Mar. 31, 1902, ch. 148, $\S 1,1902$ Iowa Acts 107; Act of July 9, 1896, No. 69, § 1, 1896 La. Acts 102; Act of Apr. 12, 1921, ch. 224, § 1, 1921 Minn. Laws 277; Act of Mar. 30, 1911, 1911 Mo. Laws 198; Act of Apr. 8, 1913, ch. $69, \S 1,1913$ Neb. Laws 203, 203; Act of Mar. 1, 1886, ch. 31, \& 6, 1886 N.Y. Laws 39, 41; N.D. Comp. Laws $\S 9615$ (1913); Act of Apr. 12, 1889, $\S 1,1889$ Ohio Laws 251; Act of Jan. 13, 1913, ch. 21, 1913 Or. Laws 56; Act of Feb. 17, 1923, ch. 13, 1923 Utah Laws 21; Act of Mar. 18, 1916, ch. 295, 1916 Va. Acts 511; Act of Mar. 22, 1909, ch. 249, § 204, 1909 Wash. Laws 890, 950; W. VA. CODE ch. 61, art. 8, $\S 13$ (1931); Act of Apr. 9, 1897, ch. 198, 1897 Wis. Laws 359; Wyo. Rev. STAT. § 5067 (1899).

156. Act of June 10, 1903, No. 198, \& 1, 1903 Mich. Pub. Acts 295; see also Act of May 26, 1939, No. 148, 1939 Mich. Pub. Acts 294 (adding crime of gross indecency between females).

157. Act of June 16, 1887, \& 1, 1887 Mass. Acts 1099.

158. Act of Mar. 7, 1899, ch. 33, 1899 N.H. Laws 270.

159. Act of Apr. 18, 1916, 1916 Md. Laws 1296.

160. Act of Feb. 15, 1917, ch. 2, § 1, 1917 Ariz. Sess. Laws 2.

161. Act of May 28, 1917, ch. 7361, No. 103, $\S 1$, 1917 Fla. Laws 211.

162. Act of Apr. 2, 1906, ch. 71, 1906 N.J. Laws 101.

163. Act of June 1, 1915, ch. 586, sec. $1, \S 288(\mathrm{a}), 1915 \mathrm{Cal}$. Stat. 1022, repealed and replaced by Act of June 3, 1921, ch. 848, 1921 Cal. Stat. 1633.

164. 21 S.W. 360, 360-61 (Tex. Crim. App. 1893) (followed in Mitchell v. State, 95 S.W. 500, 500 (Tex. Crim. App. 1906)); see also Munoz v. State, 281 S.W. 857, 857 (Tex. Crim. App. 1926); Harvey v. State, 115 S.W. 1193, 1193 (Tex. Crim. App. 1909) (opining charge of oral sex "too horrible to contemplate," and legislation must be adopted to cover "these unnatural crimes").

165. Prindle, 21 S.W. at 361 (quoting Ex parte Bergen, 14 Tex. App. 52, 53 (1883)) 
follow the common law, which limited sodomy to anal sex. The judges expressed anguish that the law failed to reach this abominable phenomenon, but opined that the legislature should fix the problem. ${ }^{166}$ Prindle was followed in California (1897), Kentucky (1909), Nebraska (1910), Arizona (1912), Utah (1913), Virginia (1923), Colorado (1927), and (much later) New Mexico (1953). ${ }^{167}$ In all these states, except New Mexico, the narrow judicial interpretation was overridden by legislation broadening the definition of sodomy or, in the cases of California and Arizona, creating a new crime. ${ }^{168}$

By the turn of the century, however, the specification of sodomy to include oral sex sometimes came through dynamic police and judicial interpretation of old sodomy laws. Because state laws used elastic terms such as "crime against nature" or "carnal knowledge," without definition or elaboration, judges could reason from the underlying goals of sodomy laws: oral sex was analogous to anal sex (sodomy) in their shared "unnaturalness," or inability to contribute to the procreative project. As the Illinois Supreme Court said in the leading case, Honselman v. People, oral sex "is as much against nature ... as sodomy or any bestial or unnatural copulation that can be conceived."169 Honselman was followed by the highest courts of Georgia (1904), South Dakota (1910), North Carolina (1914), Alabama (1914), Nevada (1914), Delaware (1915), Montana (1915), Idaho (1916), Oklahoma (1917), Hawaii (1922), and Kansas (1925). ${ }^{170}$ Note that these are rural states of the South and West for the most part. States with big cities (apart from Illinois) all accomplished the new regulation by prospective legislation.

The legal process of statutory amendment and dynamic judicial and police interpretation of sodomy laws entailed an analytical discourse specifying what was forbidden and what was acceptable sexual conduct. The 1879 Pennsylvania law identified for the first time precisely what body parts could be involved in the crime against nature

166. See id.

167. See Weaver v. Territory, 127 P. 724, 724 (Ariz. 1912); People v. Boyle, 48 P. 800, 800 (Cal. 1897); Koontz v. People, 263 P. 19, 21-22 (Colo. 1927); Commonwealth v. Poindexter, 118 S.W. 943, 944 (Ky. 1909); Kinnan v. State, 125 N.W. 594, 594-95 (Neb. 1910); Bennett v. Abram, 253 P.2d 316, 317 (N.M. 1953); State v. Johnson, 137 P. 632 (Utah 1913); Wise v. Commonwealth, 115 S.E. 508, 509-11 (Va. 1923).

168. See Act of Feb. 15, 1917, ch. 2, § 1, 1917 Ariz. Sess. Laws 2; Act of June 1, 1915, ch. 586, sec. 1 , \& 288(a), 1915 Cal. Laws 1022, repealed and replaced by Act of June 3, 1921, ch. 848, 1921 Cal. Laws 1633; Act of Apr. 3, 1939, ch. 97, 1939 Colo. Sess. Laws 318; Act of Apr. 2, 1974, ch. 406, §§ 87-90, 1974 Ky. Acts 831, 847; Act of Apr. 8, 1913, ch. 69, 1913 Neb. Laws 203; Act of Mar. 4, 1955, ch. 78, 1955 N.M. Laws 132; Act of Feb. 17, 1917, ch. 13, 1923 Utah Laws 21; Act of Mar. 20, 1924, ch. 358, 1924 Va. Acts 516.

169. 48 N.E. 304, 305 (Ill. 1897).

170. See Herring v. State, 46 S.E. 876 (Ga. 1904); State v. Whitmarsh, 128 N.W. 580 (S.D. 1910); State v. Fenner, 80 S.E. 970 (N.C. 1914); Woods v. State, 64 So. 508 (Ala. 1914); Ex parte Benites, 140 P. 436 (Nev. 1914); State v. Maida, 96 A. 207 (Del. 1915); State v. Guerin, 152 P. 747 (Mont. 1915); State v. Altwatter, 157 P. 256 (Idaho 1916); Ex parte De Ford, 168 P. 58 (Okla. 1917); Territory v. Wilson, 26 Haw. 360 (1922); State v. Hurlbert, 234 P. 945 (Kan. 1925). 
and that level of statutory detail gradually became the norm as states revised their sodomy laws in the next generation. Relatedly, judicial opinions reviewing sodomy convictions, which were often just a paragraph in length earlier in the century, began to describe the circumstances of the crime and the relationship of the parties, rather than just announcing that "unmentionable" conduct had occurred. Most of the opinions engaged in a reasoning process, rather than just denouncing the "abominable" nature of the conduct and the crime. (These developments occurred later in the South.) Treatises and practice manuals chatted about the crime against nature. This legal discourse paralleled the medical and popular discourse that was creating the idea of "sexuality" in the West during this era.

\section{The Transformations of Sodomy Laws, 1920-1986}

Sodomy laws went through several more transformations in the two generations after World War I. The main transformation was an explicit association of sodomy (the act) with homosexuality (the status) - and the association of both with child molestation (act) and sexual psychopathy (status). As mainstream society focused increasing attention onto the homosexual-identifying, hunting, and suppressing him-homosexuals started thinking of themselves as a minority group, with possible legal rights. Once the objects of regulatory discourse ("sodomites," "degenerates," "homosexuals") announced their personal subjectivities, it became possible to talk about "consensual" as opposed to "forcible" sodomy or sodomy with a minor. During the antihomosexual mania following World War II, informed opinion questioned whether sodomy laws should be applied to intercourse between consenting adults. This did not translate into actual sodomy law repeal until the 1970s, when the laws dropped like flies and, except in the South, largely ceased to be enforced against adults having consensual sex with one another in private places.

\section{The Sodomite as Sexual Psychopath, 1921-1946}

World War I was one watershed in the enforcement of sodomy laws. In cities such as New York, San Francisco, Baltimore, Chicago, Boston, St. Louis, and Philadelphia, sodomy arrests during the 1920s continued at a significantly higher level than before the war. ${ }^{171}$ Another big shift in the statistics came during and after the Great Depression. The big cities of the East, Midwest, and West Coast continued to arrest many people for sodomy, and the crime began to be enforced regularly by cities in the South as well. ${ }^{172}$ There is some evidence of stronger sex law enforcement activity, generally, in the

171. See Eskridge, supra note 109, at 1111.

172. See id. at 1117 app. 2C, 1112 app. 2A. 
1930s. ${ }^{173}$ What is most remarkable, in this regard, was the boom in arrests of homosexuals for public activities such as cruising, dancing, cross-dressing, kissing, groping, fondling, and even hand holding in public or semipublic spaces. Such public activity could violate any number of state or municipal laws-including laws prohibiting disorderly conduct, sexual solicitation, lewdness, indecent exposure, vagrancy, loitering, and cross-dressing or even "disguise." 174 These (public) conduct laws eclipsed (private) sodomy laws as means of policing homosexuals or suppressing their culture. To take a dramatic example, in 1949 New York City arrested 112 men for sodomy, but 931 for violating the disorderly conduct law provision covering "degenerate" acts, and a whopping 2213 for violating a law against loitering around public toilets. ${ }^{175}$

The raw statistics reflected a shift in American thinking about sex offenses in the 1920 s and 1930 s. ${ }^{176}$ Reflecting concepts about sexuality propounded by the American followers of Freud, regulators focused their concern on the "sexual psychopath"-the aggressive male who could not control his impulses and threatened children. The homosexual male was identified as the quintessential sexual psychopath, and regulatory attention was sharply focused on this new creature. Responsive to this alarm were a series of "sexual psychopath" laws, which allowed the state to incarcerate sex offenders for indeterminate periods of time, until they were cured. The first laws were enacted in Michigan in 1935 and Illinois in $1937 .{ }^{177}$ More than half the state legislatures (including those in all the big-city states) and Congress, for the District of Columbia, followed the Michigan-Illinois experiment with sexual psychopath laws between 1939 and $1960 .{ }^{178}$ A large portion of the men arrested under these laws were homosexual men, sometimes engaging in consensual oral sex and sometimes engaging in sex with minors. ${ }^{179}$ Conversely, the increase in sodomy law enforcement included adult men having sex with other adult men, but the overwhelming majority of arrests in New York and California were for unconsented sodomy with women and minors. ${ }^{180}$

173. See id. at 1121 app. $2 \mathrm{E}$.

174. See id. at 1032-45.

175. See Morris Ploscowe, Sex and the Law 208 (1951).

176. The best source on this shift is Estelle B. Freedman, "Uncontrolled Desires": The Response to the Sexual Psychopath, 1920-1960, 74 J. AM. Hist. 83 (1987). Lucid contemporary conceptualization along the lines that follow can be found in Bernard C. Glueck, An Evaluation of the Homosexual Offender, 41 MiNN. L. REv. 187 (1956).

177. See William N. Eskridge, Jr., Privacy Jurisprudence and the Apartheid of the Closet, 1946-1961, 24 Fla. ST. U. L. Rev. 703, 825 app. 4 (1997).

178. The laws are collected, described, and analyzed in Eskridge, supra note 177, at 703; see also Alan H. Swanson, Sexual Psychopath Statutes: Summary and Analysis, 21 CRIM. L. ComMENTS \& ABSTRACTS 215 (1960).

179. See Paul Tappan, The Habitual Sex Offender: Report and Recommendations of the Commission on the Habitual Sex OfFender 28-29 (1949).

180. See Eskridge, supra note 109, at 1060. 


\section{The Impulse to Reform, 1947-1961}

The McCarthy era, roughly 1947 through 1957, witnessed unprecedented numbers of arrests for consensual oral sex between adults, because local vice squads invested substantial resources in detection of private and semipublic activities. ${ }^{181}$ Ironically, it was during that period that a modest sodomy law reform movement began. The first public retreat from the antihomosexual sodomy regime began with New York Governor Thomas Dewey's veto of a sexual psychopath law in $1947 .{ }^{182}$ Dewey opposed the law because it was not grounded in expert opinion about what would actually contribute to the state's struggle against child molestation. A study commission headed by Dr. Bernard Glueck laid the groundwork for and drafted a 1950 law that required psychiatric reports to assist the sentencing of sex offenders and provided for indeterminate sentences and medical treatment in appropriate cases. ${ }^{183}$ Most significantly, the 1950 statute reduced the crime of consensual sodomy to a misdemeanor; forcible sodomy and sodomy with a minor, the primary focus of concern according to Glueck's reports, remained serious felonies. ${ }^{184}$

Sex offender study commissions dominated by medical and legal experts filed influential reports in New Jersey, Michigan, Illinois, California, and other states. ${ }^{185}$ Following Paul Tappan's suggestions in New Jersey's report on sex offenders, the Illinois Commission on Sex Offenders, chaired by Professor Francis Allen of Northwestern University Law. School, constructed its 1953 report around the "distinction . . . between sexual deviates whose conduct in the community offends morals (homosexuals, exhibitionists), and dangerous, aggressive offenders whose behavior is a community threat (aggressive rapist[s], etc.)."186 Like Tappan and the New Jersey Commission, the Illinois Commission urged regulatory action to focus on (1) "repetitive compulsive acts" (peeping toms), (2) "forced relations," and (3) relations involving an adult and a minor. ${ }^{187} \mathrm{~A}$ thesis of both reports, as well as those in California and New York, was that consensual same-

181. See Eskridge, supra note 177, at 724-33.

182. See Commissioner of Mental Hygiene \& Comm'r of Correction, Report on Study of 102 Sex Offenders at Sing Sing Prison 11 (1950).

183. See Bernard C. Glueck, Final Report: Research Project for the Study and Treatment of Persons Convicted of Crimes Involving Sexual Aberrations (1955).

184. See Act of Apr. 11, 1950, ch. 575, \& 15, 1950 N.Y. Laws 1271, 1278-79.

185. See California Dep't of Mental Hygiene, Final Report on California Sexual Deviation Research (1954); Illinois Comm'n on Sex OfFenders, Report on the Illinois Commission on Sex OfFenders to the 68Th General Assembly of the State of Illinois (1953) [hereinafter Illinois Comm'n on Sex OfFenders]; Governor's Study Comm'N, Report of the Governor's Study Commission on the Deviated Criminal Sex Offender (Mich. 1958); Paul W. Tappan, N.J. Comm'n on the Habitual Sex Offender, The HabitUal Sex Offender: Report and Recommendations of the Commission on the Habitual SEX OFFENDER (1949).

186. Illinors Comm'N on Sex OfFenders, supra note 185, at 11.

187. Id. at 9 . 
sex intimacy in private places was essentially not the concern of the law. Indeed, application of the criminal sanction in such cases had deleterious effects-diverting police resources from serious crimes like rape and child molestation, providing opportunities for blackmail, and possibly contributing to police and other public corruption.

Following the New York, Illinois, and New Jersey sex offender commissions and echoing their libertarian reasoning, the influential American Law Institute (ALI) narrowly voted in May 1955 to decriminalize consensual sodomy in a tentative draft of its proposed Model Penal Code. ${ }^{188}$ Expressly adopting a Millian, libertarian position, the ALI explained that "[n]o harm to the secular interests of the community is involved in a typical sex practice in private between consenting adults. This area of private morals is the distinctive concern of spiritual authorities." 189 The drafters invoked the "protection to which every individual is entitled against state interference in his personal affairs when he is not hurting others." ${ }^{190}$ Criminalizing such practices sapped valuable police resources, fueled blackmail rings, and undercut "the protection to which every individual is entitled against state interference in his personal affairs when he is not hurting others." 191

In 1961, a coalition of lawyers and medical experts chaired by Professor Charles Bowman of the University of Illinois persuaded the Illinois legislature to adopt the Model Penal Code and thereby to eliminate criminal sanctions for adult consensual sodomy. ${ }^{192}$ Law revision commissions in Minnesota, New York, and Maryland made similar proposals that were considered and rejected by their state legislatures in the 1960s. ${ }^{193}$ Florida and other states debated such a move, with medical experts and law professors supporting it and law enforcement officers and religious groups generally in opposition. ${ }^{194}$ The main argument raised against repealing sodomy laws was that such a move would reflect state tolerance or even approval of homo-

188. This move was made in section 207.5 of Tentative Draft No. 4 of the proposed Model Penal Code, which also decriminalized fornication, adultery, and other sexual crimes not involving violence or children. See Louis Henkin, Morals and the Constitution: The Sin of Obscenity, 63 Colum. L. Rev. 391 (1969).

189. Model Penal Code $\$ 207.5 \mathrm{cmts}$. (Tentative Draft No. 4 1955); see also Louis B. Schwartz, Morals Offenses and the Model Penal Code, 63 Colum. L. Rev. 669, 675-76 (1963).

190. Model Penal Code $\S 207.5$ cmts. (Tentative Draft No. 4 1955).

191. Id.

192. See Eskridge, supra note 177 , at 775.

193. See Robert G. Fisher, The Sex Offender Provisions of the Proposed New Maryland Criminal Code: Should Private, Consenting Adult Homosexual Behavior Be Excluded?, $30 \mathrm{MD}$. L. Rev. 91, 104-11 (1970).

194. See Eskridge, supra note 177, at $775-77,829$ app. 6 (summary transcript of Florida revision commission debate). 
sexuality. ${ }^{195}$ No other state decriminalized consensual sodomy until Connecticut did so in its 1969 criminal code revision. ${ }^{196}$

\section{Legal Shift from Consensual to Forcible Sodomy, 1969-1986}

As written, Griswold celebrated the "bilateral loyalty" of companionate marriage, and not sexual liberty. Concurring opinions by Justices Harlan and Goldberg distanced the case from "homosexuality." 197 In the context of the Millian debate instigated by the Model Penal Code and by an increasingly vocal gay-rights movement, however, Griswold was revolutionary. It opened federal courts, for the first time, to serious constitutional claims that the state could not criminalize sodomy and other sexual activity between consenting adults in private spaces.

The pace of constitutional challenge and legal reform quickened considerably after $1969 .{ }^{198}$ One reason was the burgeoning gay liberation movement unleashed by the Stonewall riots of June 1969-which propelled a whole generation of gay people out of the closet and into the public arena. Relatedly, women's liberation and the new acceptability of nonmarital sex pressed for a broader view of the privacy right-from the marital right in Griswold to a right to sexual pleasure in the home (Stanley), to sexual intimacy among unmarried persons (Eisenstadt), and to control of one's pregnant body (Roe). The Millian ideal of the Model Penal Code gained ground during the sexual revolution of the 1960 s and early 1970 s.

The political energy released by these developments invigorated the movement to nullify or ameliorate consensual sodomy laws. Between 1969 and 1975, twelve state legislatures followed Illinois to repeal their consensual sodomy laws: California, Colorado, Connecticut, Delaware, Hawaii, Maine, New Hampshire, New Mexico, North Dakota, Ohio, Oregon, Washington. ${ }^{199}$ In three states (Alaska, Florida, Massachusetts), courts partially invalidated their state laws. ${ }^{200} \mathrm{By}$ the beginning of 1981, eleven more states had revoked all criminal penalties for private sodomy between consenting adults-eight by statute (Alaska, Indiana, Iowa, Nebraska, South Dakota, Vermont, West Virginia, Wyoming), two by judicial decision (New York, Pennsylvania), and one by a joint effort (New Jersey). ${ }^{201}$ Twelve other states by 1981 had either reduced consensual sodomy from a felony to a misde-

195. See id. at 776 .

196. See William N. Eskridge, Jr., Challenging the Apartheid of the Closet: Establishing Conditions for Lesbian and Gay Intimacy, Nomos, and Citizenship, 1961-1981, 25 HofsTRA L. REv. 817, 843 (1997).

197. See Griswold v. Connecticut, 381 U.S. 479, $485-86$ (1965); id. at 486 (concurring opinions).

198. See Eskridge, supra note 196, at 819-28, 842-57.

199. See infra Appendix.

200. See infra Appendix.

201. See infra Appendix. 
meanor (Alabama, Arizona, Arkansas, Kansas, Kentucky, Missouri, Tennessee, Texas, Utah, Wisconsin) or circumscribed the penalty to misdemeanor level (Minnesota, Nevada). ${ }^{202}$ In less than a generation, almost four-fifths of the states declassified consensual sodomy as a felony. This was remarkable.

Equally remarkable was the opposition to sodomy repeal, for the possibility of gay liberation from criminal sanction helped galvanize traditionalist "religious right" coalitions in many states. California's repeal in 1975 followed an intense debate in which a highly orchestrated opposition argued that decriminalizing "homosexuality" would lead to venereal disease and send a message to impressionable children that "homosexuality is okay."203 The strategy of isolating sodomy to homosexuality and exploiting social homophobia worked better in states of the Baptist South and Mormon West. Idaho in 1971 adopted a new criminal code, closely tracking the Model Penal Code, that decriminalized consensual sodomy. ${ }^{204}$ When this fact gained public attention, religious leaders objected that Idaho would become a haven for "sex deviates," and the legislature in 1972 repealed the new code and reinstated the old one-for no other reason than to express antihomosexual policies. ${ }^{205}$ Arkansas had the same reaction when it adopted a Model Penal Code type reform, but its legislative response was more typical: the legislature in 1977 reinstated consensual sodomy as a crime, albeit only as a misdemeanor and only applicable to samesex (homosexual), not different-sex (heterosexual) sodomy. ${ }^{206}$ Seven of the twelve misdemeanor laws (Arkansas, Kansas, Kentucky, Missouri, Nevada, Tennessee, Texas) plus the felony law of Montana criminalized only homosexual, and not heterosexual, sodomy. ${ }^{207}$

Enforcement of sodomy laws also changed after 1961. In the 1960 s and early 1970s, urban police forces arrested more gay people than ever before for consensual, adult sexual activities, but they were met, for the first time, with organized opposition. Homophile and gay liberation groups in New York, San Francisco, Washington, D.C., and elsewhere protested police harassment through selective enforcement of sodomy and solicitation laws. ${ }^{208}$ Following this pressure and the views of an increasing number of experts, the focus of sodomy law prosecution shifted decisively after 1969, away from cases of consensual homosexual intimacy, toward cases of forcible sodomy, usually by

202. See infra Appendix.

203. Eskridge, supra note 196 , at 849.

204. See id. at $847 \&$ n.123. The statutory references are in the Appendix to this article.

205. See id.

206. See Act of Mar. 28, 1977, No. 828, § 1, 1977 Ark. Acts 2118, 2118-19.

207. See references for these states in the Appendix to this article. Oklahoma achieved the same result by judicial decision invalidating the state sodomy law as it applied to heterosexual intercourse, but not homosexual intercourse. See Post v. State, 715 P.2d 1105 (Okla. Crim. App. 1986).

208. See Eskridge, supra note 196, at 828-42. 
a man against a woman, and sodomy with minors, usually by men with girls (often daughters or stepdaughters) ${ }^{209}$ Outside the South, sodomy laws were rarely if ever enforced against consenting adults, homosexual or heterosexual. Almost all of the reported cases involving consensual sodomy after 1969 arose in the South, whose police continued to use decoy cops to entrap gay people and to spy on patrons of public rest rooms and adult bookstores long after such practices dried up in New York, San Francisco, Los Angeles, and other large cities in the Northeast, Midwest, and West. ${ }^{210}$ Thus, when the Atlanta police harassed and ultimately arrested Michael Hardwick in $1982,{ }^{211}$ they were playing an old game, but one that was increasingly controversial. That five Justices of the Supreme Court validated their arrest, however, was just the beginning of a new, critical chapter in the ongoing history of laws regulating consensual sodomy.

\section{A Historicist Critique of HaRdwick}

Like most lawyers, Justice White was using history for argumentative, rhetorical, or even partisan purposes. That the historical, and historiographical, story is more complex can hardly be surprising. I disagree with Justice White's understanding of precedent, history, and "homosexual sodomy," but do not want to mirror his mistake by simply debunking his history and turning it, with equal simplicity, to Hardwick's advantage. A more sophisticated understanding of history enables us to understand Bowers v. Hardwick more deeply. And while it does corrode the persuasiveness of the Court's opinion, history, properly understood, raises more questions than it answers, in this case and in others as well.

As Anne Goldstein has argued, Justice White's opinion is anachronistic-conflating oral sex with sodomy and the new twentieth century category "homosexual" with the historic biblical category of "sodomy." 212 The history presented in part II of this article elaborates on her point in irrefutable detail, but the question remains: So what? Why should a more sophisticated history of sodomy laws, and the novelty of their application to oral sex matter? Is the history relevant to the Court's normative inquiries, namely, making sense of the precedents and suggesting a limiting principle for the privacy right? In this part, I maintain that a more nuanced historical account helps us understand deeper inconsistencies between Hardwick and the previous precedents, the erosion of professional and academic support for

209. This claim will be documented in William N. Eskridge, JR., Gaylaw: Challenging the Apartheid of the Closet (forthcoming from Harvard University Press, 1999).

210. See, e.g., State v. Enslin, 214 S.E.2d 318 (N.C. Ct. App. 1975); Leibman v. State, 652 S.W.2d 942 (Tex. Crim. App. 1983).

211. The story behind the case is told in Hardwick's own words in Peter Irons, The CourAGE OF THEIR CONVICTIONS 392-403 (1988).

212. See Goldstein, supra note 16, at 1081-89. 
Hardwick and its current outlier status, and inherent practical as well as conceptual difficulties with originalism as a constitutional methodology.

\section{A. Sodomy and Normalizing Regimes}

Criminal laws operate both negatively and positively. They act negatively by stigmatizing certain conduct; they act positively by normalizing the conduct not prohibited. The rational basis test of the Due Process Clause all but requires a normalizing as well as stigmatizing goal for criminal laws. From the perspective of the eighteenth- and nineteenth-century Framers of the Fifth (1791) and Fourteenth (1868) Amendments, sodomy laws can be thought of as reflecting any or all of three normalizing regimes: carnal pleasure is immoral or illegal unless it is both procreative and marital, must be nonpredatory, or must reflect traditional gender roles of insertive man and receptive woman. Justice White, however, chose an option unavailable to the Framers of the Fifth and Fourteenth Amendments, whose intent he invoked. ${ }^{213}$ This is another way of showing how an original intent methodology cannot coherently support Justice White's choice in Michael Hardwick's case.

The Framers of the Fourteenth Amendment (1868) or the Fifth Amendment (1791) would have rationalized sodomy laws as requiring that sex occur within procreative marriage. That was the biblical rationale and the one accepted by both Roman Catholic and Protestant theologians for centuries. It was the normalizing regime supported by colonial and early American morals legislation. By prohibiting fornication (penile-vaginal sex by unmarried men and women), adultery (penile-vaginal sex by men and women who were married but not to each other), rape (always defined to be outside of marriage), and sodomy (specifically, anal sex), the early colonies and the states were reinforcing the cultural message that carnal pleasure must be procreative and must occur within marriage.

But Justice White did not emphasize the Framers' normalizing regime as the justification for sodomy laws, because it was foreclosed by the Court's precedents. The Court's earliest privacy decisions, Griswold, Eisenstadt, and Roe, recognized as fundamental a woman's and a man's right not to procreate when they had penile-vaginal intercourse. Although Griswold emphasized marriage as a locus for privacy, Roe and Eisenstadt expanded privacy rights to nonmarital contexts. Read together, these precedents found protection for carnal liberty in the Due Process Clause and rejected the marriage- and procreation-based regime of the colonial period and the early Republic. The right of privacy, as the Court has articulated it, is inconsistent

213. See Bowers v. Hardwick, 478 U.S. 186, 192-94 (1986). 
with Justice White's narrow originalism, and so the Hardwick inquiry started with incoherent premises.

The incoherence of an originalist approach is even worse in Hardwick's case, for the oral sex for which he was arrested was not known as "sodomy" or the "crime against nature" in any American jurisdiction in 1791 or 1868 . Oral sex might conceivably have been proscribed by the New Haven statute of 1656 or by John Cotton's proposed but rejected law for Massachusetts Bay, but it was not on the regulatory agenda after the Revolution or the Civil War. Even as late as 1868, there was no authoritative American statute or judicial decision disagreeing with the English rule that oral sex was not a crime against nature. ${ }^{214}$

That legal equilibrium changed in the last quarter of the nineteenth century and the first quarter of the next. Significantly, a large majority of the states accomplished the transition by statute, creating a new crime that was by definition prospective in operation. Almost all the biggest states, those with urban populations, engaged in this prospective process: Pennsylvania, New York, Massachusetts, New Jersey, Virginia, Florida, Texas, Ohio, Michigan, and California. ${ }^{215} \mathrm{Ja}-$ net Halley points out that Georgia's decisions declaring oral sex to be a crime against nature purported to declare preexisting "natural law," and not to innovate new law. ${ }^{216}$ This reflects judges' tendency to deny legal innovation, especially when interpreting criminal laws, once the idea of "common law crimes" became suspect (as it did in the late nineteenth century), and not any consensus that oral sex had been a crime against nature "all along." Indeed, Georgia was the only medium-population state to follow Illinois's Honselman decision, and Georgia's judges were openly ambivalent about their innovation. In a 1904 libel case (not a criminal prosecution) the Georgia Supreme Court found fellatio to be sodomy. The court extended that idea to male-on-female cunnilingus in 1917, found cunnilingus between two women not to be sodomy in 1939, and overruled the application of sodomy law to any kind of cunnilingus in $1963 .{ }^{217}$ It was not completely clear until a statutory rewrite in 1968 that all kinds of oral sex were sodomy in Georgia. ${ }^{218}$

214. The first mention of oral sex as possible sodomy that I have found in the commentaries, is William L. Clark \& William L. Marshall, A Treatise on the Law of Crimes 706 n.415 ( $2 \mathrm{~d}$ ed. 1912). Compare the earlier treatises, cited in supra note 97.

215. See infra Appendix.

216. See Halley, supra note 13 , at 1760-67.

217. See Riley v. Garrett, 133 S.E.2d 367 (Ga. 1963) (overruling application of sodomy law to cunnilingus); Thompson v. Aldredge, 200 S.E. 799 (Ga. 1939) (finding cunnilingus between two women not sodomy); Herring v. State, 46 S.E. 876 (Ga. 1904) (finding fellatio to be sodomy); Comer v. State, 94 S.E. 314 (Ga. Ct. App. 1917) (finding cunnilingus to be sodomy).

218. See Act of Apr. 10, 1968, ch. 26-20, 1,1968 Ga. Laws 1249, 1299 (adding GA. Code ANN. § 26-2002 (1968)). 
In short, Justice White's originalist approach to the Fourteenth Amendment stands in contrast not only to the Court's previous refusal to follow an originalist approach to that amendment in Griswold and Roe, but also to Justice White's own nonoriginalist approach to the state sodomy laws he charged the Framers with knowing and approving. ${ }^{219}$ At the level of specific intent, it would not have occurred to a single Framer that sodomy involved consensual oral sex. At the level of general intent, every Framer would have thought the purpose of sodomy laws to be assurance that carnal pleasure could occur only within the context of procreative marriage, an unconstitutional goal under the Court's post-1960 privacy jurisprudence.

It might be objected that, if the Framers had "thought about" or "known about" oral sex, they would have been so appalled that they would have considered it a crime against nature. They probably would have been appalled, ${ }^{220}$ but not every appalling thing was sodomy, as the common law firmly held. ${ }^{221}$ Moreover, the Framers might have been reluctant to categorize consensual oral sex as sodomy, because their second-best rationale for sodomy laws was protection of vulnerable people and animals against predatory rape-like conduct. At common law, sodomy and rape were sibling crimes. Both were considered "carnal knowledge" entailing violent assaults upon the person of the victim, ${ }^{222}$ the law originally required penetration and emission in both crimes but abandoned the emission requirement for both in the nineteenth century, ${ }^{223}$ and consent on the part of the accomplice made it harder and usually impossible to prove each crime. As to the last point, where the victim of sodomy consented to the act, her or his evidence required independent corroboration. ${ }^{224}$ Such corroboration would have been highly unlikely when the sodomy was committed in a private space. ${ }^{225}$ Likewise, a rape conviction required corroboration of

219. Note, too, that Justice White abandoned any pretense to an originalist methodology when he reconceived Georgia's sodomy law as antihomosexual-in the teeth of the statute's plain text and the legislature's express goal of extending the law to cover male-female cunnilingus when it amended the statute in 1968. See infra Appendix.

220. Oral sex was hardly unknown to the Anglo-American world before 1879. It was, for example, obliquely described in John Cleland, FanNy Hill: Memoirs of a Woman of PleaSURE 42-43 (Dell rev. ed. 1964) (1749), a bawdy novel banned as obscene in many states. (I owe this reference to Professor Courtney Howland.)

221. Some appalling things might have been prosecuted as "lewdness," but there is no reported case of that type that $I$ have found for the nineteenth century, and lewdness at common law required public conduct.

222. See 2 Bishop, supra note 97 , 1027 , at 731; see also, e.g., Davis v. State, 3 H. \& J. 154, 154 (Md. 1810) (stating defendant "with force and arms . . . did make an assault ... beat, wound, and illtreat" a 19-year-old youth).

223. See 2 Bishop, supra note 97, § 1027, at 731; see also People v. Hodgkin, 53 N.W. 794 (Mich. 1892) (describing Michigan law and citing generally to Bishop on Criminal Law).

224. See Wharton, supra note 104 , at 443.

225. For example, in Medis v. State, 11 S.W. 112 (Tex. Ct. App. 1889), Milton Werner, the person being sodomized, was the only witness to penetration. Two other witnesses saw defendant Charles Medis (but not defendant Ed Hill) atop Werner. The witnesses heard Werner exclaim that he would be "served" next. When the witnesses made their presence known, all three par- 
the complaining witness unless she could show that she had actively resisted. In both rape and sodomy, there was no corroboration requirement for minors, who were legally incapable of consent. ${ }^{226}$ For the foregoing reasons, I have not seen a reported case in the United States before 1900 where it is clear that a sodomy conviction was upheld against a man engaged in private consensual intercourse with another adult man, as Hardwick was. ${ }^{227}$

A third possible rationale for sodomy laws was their reinforcement of traditional gender roles in sexual intercourse-a thrusting aggressive male penetrating a receptive female with his penis. This would have been a more comprehensible rationale to the Framers of the Fourteenth Amendment than those of the Fifth, because the Civil War period was the time when gender roles were hardening. In the big cities of the North, Midwest, and West sodomy laws became seriously enforced only after gender "inverts" became a troubling public spectacle. Under this normalizing regime, Michael Hardwick might have been characterized as a gender invert, because he had another man's penis in his mouth. But this option, too, was unavailable to Justice White, because of the Court's sex discrimination precedents. Starting with Frontiero v. Richardson ${ }^{228}$ and Craig v. Boren, ${ }^{229}$ a line of Supreme Court decisions rejected legal rules grounded or defended on the basis of traditional stereotypes about male and female roles. In light of these precedents, Justice White was not about to criminalize Hardwick for violating male gender expectations.

Instead, he faulted Hardwick for being a "homosexual" sodomite. In so doing, Justice White opted for a twentieth-century rather than nineteenth-century justification for sodomy laws, as part of a regime of compulsory heterosexuality. Under the historically recent regime of compulsory heterosexuality, it is only "homosexual sodomy," and not "heterosexual sodomy" that is at issue. Justice White's exegesis of sodomy laws around the homo/heterosexual dichotomy would have been, literally, incomprehensible to the Framers. The word "homosexual" was not coined until 1868 and did not reach the United States until 1892; "heterosexuality" came even later to the lexicon. ${ }^{230}$ The concept of "homosexual sodomy" would likewise have been meaningless to the Framers and would certainly not have been an organizing princi-

ticipants jumped away, and Werner responded to the witnesses' intent to charge Medis and Hill, by saying he "did not care a d-n." The court reversed the Medis and Hill convictions because Werner was a consenting accomplice whose testimony as to penetration was not corroborated.

226. See 1 Wharton, supra note 105 , at 512.

227. In People v. Hickey, 109 Cal. 275 (1895), for example, the state supreme court affirmed an appellate court decision to grant a new trial. There was a charge of assault as well as sodomy, but the court also stated in dictum that sodomy could be established notwithstanding consent. See id. at 276.

228. 411 U.S. 677 (1973).

229. 429 U.S. 190 (1976).

230. See Jonathan Ned Katz, The Invention of Heterosexuality 10 (1995). 
ple for them. Nor can it be shown that the Framers believed same-sex sodomy was any more reprehensible than other kinds of sodomy. Following the common law, nineteenth-century sodomy laws applied to male-female as well as male-male sodomy; most statutes, such as Georgia's, did not apply to female-female sodomy. Excluding the large number of decisions that did not reveal the sex or even the species of the parties involved, ${ }^{231}$ the reported appellate cases from the nineteenth century fell into three roughly equal groups: bestiality with barnyard animals, ${ }^{232}$ sex between an adult man and a boy or "youth," 233 and man-man and man-woman cases, typically involving coercion. ${ }^{234}$ There are no reported cases involving woman-woman sodomy. One would read the pre-1900 cases in vain to find any mention of or reference to homosexuality. The main concern was the commission of nonprocreative acts outside of marriage; a secondary concern was predation by men against youths, women, and animals; a later concern was inversion of gender roles. There was no concern with policing homosexuality, a specifically same-sex eroticism whose existence was not even recognized.

Thus, Justice White's choice of a normalizing regime for sodomy laws had nothing to do with the expectations of the eighteenth- and nineteenth-century legislatures that adopted such laws, or of the Framers of the Fifth and Fourteenth Amendments. His choice was his choice, not the Framers' choice. His choice was rooted in twentiethcentury law's creation of the "homosexual" as the object of criminalization and erasure. His choice tracked the choice made by seven state legislatures in the 1970s and two state high courts after Hardwick, which reconfigured sodomy law around homosexual conduct and not

231. See, e.g., State v. Williams, 34 La. Ann. 87 (La. 1882); Commonwealth v. Dill, 36 N.E. 472 (Mass. 1894); People v. Hodgkin, 53 N.W. 794 (Mich. Ct. App. 1892); Fennell v. State, 32 Tex. 378 (1869); Ex parte Bergen, 14 Tex. App. 52 (1883); Williams v. Commonwealth, 22 S.E. 859 (Va. 1895).

232. See Bradford v. State, 16 So. 107 (Ala. 1894) (defendant accused of intercourse with a cow); Collins v. State, 73 Ga. 76 (1884) (bestiality); State v. Frank, 15 S.W. 330 (Mo. 1891) (dog); State v. Campbell, 29 Tex. 44 (1867) (mare); Cross v. State, 17 Tex. Ct. App. 476 (1895) (mare); Commonwealth v. Thomas, 4 Va. 307 (1812) (mare).

233. See Hodges v. State, 19 S.E. 758,758 (Ga. 1894) (molesting a boy under 14 years of age); Honselman v. People, 48 N.E. 304, 306 (IIl. 1897) (affirming conviction for oral sex with 14year-old boy); Davis v. State, 3 H. \& J. 154, 154 (Md. 1810) (affirming conviction for assault on 19-year-old "youth"); Commonwealth v. Snow, 111 Mass. 411, 413 (1873) (seducing a "boy"); Territory v. Mahaffey, 3 Mont. 112, 114 (1878) (affirming conviction for seduction of a 14-yearold boy); Prindle v. State, 21 S.W. 360 (Tex. Crim. App. 1893) (reversing conviction for having oral sex with an adolescent boy).

234. See People v. Hickey, 41 P. 1047 (Cal. 1895) (involving man charged with assault and sodomy with another man); People v. Moore, 37 P. 510, 511 (Cal. 1894) (same); Foster v. State, 1 Ohio Cir. Dec. 467, 469 (Ohio Cir. 1886) (discussing case of three defendants charged with gang raping a fourth man); Lewis v. State, 36 Tex. Crim. 37 (Tex. Crim. App. 1896) (discussing defendant who committed oral and anal sex with woman); Medis v. State, 11 S.W. 112, 113 (Tex. Ct. App. 1889) (reversing the conviction of two men charged with sodomy of a third man because the only evidence of penetration came from the third man who consented to the conduct). 
just acts. ${ }^{235}$ Understood in this way, Justice White was upholding proscriptions that had neither "ancient roots," nor sanctification by "millennia of moral teaching." The "roots" of Justice White's focus on homosexuality were, instead, the middle-class anxiety about urbanized sexuality and medicalization of sex in the post-Reconstruction period of American history. According to historian Carroll Smith-Rosenberg, the same combination of anxiety and medicalization fueled the middle-class male efforts to regulate woman's bodies through laws criminalizing abortion, prostitution, and contraception. ${ }^{236}$ In other words, the homosexual was simply the last in a string of medical namings, after the abortionist and the prostitute, by a society seeking to maintain the norm of male-dominated procreative marriage.

Mark this irony. Implicitly, Hardwick contrasted abortion and contraception, which were not crimes at common law (and therefore might merit due process protection), with sodomy, which was a crime (and therefore unworthy of due process protection). But the sodomy that was a crime at common law was male-female as well as male-male rape-like anal sex-not consent-like oral sex or female-female sex or even "homosexual sodomy" as such. Oral sex was not a crime until the period 1879-1921; female-female oral sex was not a crime in most jurisdictions until well into the twentieth century; and "homosexual sodomy" was not even a concept until this century, and was not a key regulatory concept before the 1920s. In contrast, a mother's abortion before quickening became a crime in many jurisdictions before the Civil War ${ }^{237}$ and distributing contraceptives became a widely regarded crime in the Reconstruction period ${ }^{238}$-in both instances before private, consensual oral sex was a crime in a single American state. This turns Justice White's historical syllogism on its head: If the reference point is what the common law protected, or did not prohibit, in 1868 (when the Fourteenth Amendment was ratified), Michael Hardwick's conduct (not a crime anywhere until 1879 and afterward) makes out a better case for originalist protection than Estelle Griswold's conduct (a crime in some states by 1868) or Jane Roe's conduct (a crime in almost all states by 1868).

\section{B. Should Hardwick Be Overruled?}

Hardwick's antihomosexual rhetoric and questionable reasoning deprive it of at least some of the authority that derives from the Court's exercise of reasoned judgment, and lawyers and judges ought to read and apply Hardwick cautiously. This process is already afoot. Since 1986, Nevada, Rhode Island, and the District of Columbia have

235. See supra note 207 and accompanying text.

236. See Smith-Rosenberg, supra note 48 , at $178-81$.

237. See Reva Siegel, Reasoning from the Body: A Historical Perspective on Abortion Regulation and Questions of Equal Protection, 44 STAN. L. Rev. 261, 282 (1992).

238. See State v. Nelson, 11 A.2d 856, 860 (Conn. 1940). 
repealed their consensual sodomy laws, the highest state courts in Kentucky and Montana have invalidated their consensual sodomy laws under their state constitutions, a dispositive intermediate court decision in Tennessee has done the same, and nonbinding decisions in Michigan and Texas have said that their consensual sodomy laws are inconsistent with their state constitutions. ${ }^{239}$ In reported decisions after 1986, judges have generally not applied sodomy laws to private sex between consenting adults. Instead, judges have relied on Hardwick to deny equality rights to lesbians, gay men, and bisexuals, but those denials now face difficulties in light of Romer $v$. Evans. ${ }^{240}$

Should the Supreme Court overrule Hardwick? Stare decisis, the rule that even questionable precedents should not be reconsidered, is not so strong a rule in constitutional cases as in common-law and statutory cases, and the Rehnquist Court has overruled constitutional precedents frequently. ${ }^{241}$ In Planned Parenthood v. Casey, ${ }^{242}$ where the Court reaffirmed a diluted version of Roe, the plurality opinion expressed doubt about the reasoning and analytical framework of $R o e$ but insisted upon further inquiry before deciding whether to overrule it. The Casey inquiries are relevant to Hardwick, especially whether its central rule

could be removed without serious inequity to those who have relied upon it or significant damage to the stability of the society governed by [the rule in question]; whether the law's growth in the intervening years has left [Hardwick's] central rule a doctrinal anachronism discounted by society; and whether [Hardwick's] premises of fact have so far changed in the ensuing [time period] as to render its central holding somehow irrelevant or unjustifiable in dealing with the issue it addressed. ${ }^{243}$

Consider these factors in reverse order.

\section{Faulty Premises?}

Hardwick's faulty history undermines the continued justifiability of the precedent: Roe and Griswold are not easily distinguishable from Hardwick, and the Court is left with no persuasive answer to the Millian reading of the privacy precedents-one that would protect Hardwick. But the critique does not stop with the Court's ahistorical historicism. At root, the main "factual premises" the Court got wrong were its apparent assumptions about "homosexual sodomy" and about gay people. John Jeffries's sympathetic biography of Justice

239. See infra Appendix references for each state.

240. Compare the majority (relying on Hardwick) and dissenting opinions (relying on Ev. ans) in Shahar v. Bowers, 114 F.3d 1097 (11th Cir. 1997) (en banc).

241. See, e.g., Payne v. Tennessee, 501 U.S. 808, 828 (1991) (noting "[s]tare decisis is not an inexorable command").

242. 505 U.S. 833 (1992) (plurality opinion).

243. Id. at 855 (bracketed material added to tailor Casey's criteria to Hardwick). 
Powell, the most ambivalent of the Hardwick majority, demonstrates that the critical fifth vote came from a man who was unwilling to give gay people equal constitutional rights, because he considered sodomy personally repulsive and "homosexuals" completely alien. ${ }^{244}$ The Chief Justice's gratuitous concurring opinion, and his feverish lobbying of Powell to change his original vote, ${ }^{245}$ suggests that Burger was particularly threatened by homosexuality. This degree of homophobia is understandable for men of their generation, but its taint undermines the Court's claim to be a neutral arbiter of law.

As a matter of fact, gay people are normal human beings and not kooky aliens. Scientists have found gay people to be biologically as sound and psychologically as functional as straight people. ${ }^{246}$ Samesex intimacy, too, is a normal expression of sexuality. Most societies in world history have not vested gender and heterosexuality with the social significance our culture has, and even other western societies are much more accepting of the concept of benign sexual and gender variation. ${ }^{247}$ The most respectable intellectual arguments supporting antigay policies, such as those endorsed in Hardwick, are natural law arguments. ${ }^{248}$ But the procreative marriage-based regime of natural law, which is much more offended by abortion (the asserted taking of human life) than sodomy, is inconsistent with the constitutional regime of Griswold and Roe v. Wade. Again following society, the Supreme Court long ago crossed the Rubicon on these issues, moving from sectarian natural law thinking, toward a philosophy of sexual privacy and toleration of sexual variation.

Although decided only ten years after Hardwick, Evans reflects a fact-based viewpoint that is about fifty years ahead. Not only did the Court politely refer to gay men, lesbians, and bisexuals by the termi-

244. See JefFries, supra note 12 , at $515,518,521,528-29$.

245. See id. at 523-24.

246. The classic citations are Alfred C. Kinsey et al., Sexual Behavior in the Human Male (1948), and Alfred C. Kinsey et al., Sexual Behavior in the Human Female (1953); Evelyn Hooker, Male Homosexuality in the Rorschach, 22 J. Projective Techs. 33 (1958), and Evelyn Hooker, The Adjustment of the Male Overt Homosexual, 21 J. Projectrve TECHS. 18 (1957); Sigmund Freud's famous "Letter to an American Mother," excerpted in EsKRIDGE \& HUNTER, supra note 36, at 143-44. Modern authorities are collected in HoMOSEXUALITY: Social, Psychological, and Biological Issues (William Paul et al. eds., 1982); Homosexuality: Research Implications for Public Policy (John C. Gonsiorek \& James D. Weinrich eds., 1991). See also accounts from disciplines traditionally hostile to homosexuality, Kenneth Lewes, The Psychoanalytic Theory of Male Homosexuality (1988); Michael Ruse, HomosexualtTy: A Philosophical InQuiry (1988).

247. For accounts from different perspectives of sexual and gender variation across time and cultures, see Clellan S. Ford \& Frank A. Beach, Patterns of Sexual Behavior (1951); Posner, supra note 14; The Many Faces of Homosexuality: Anthropological Approaches to Homosexual Behavior (Evelyn Blackwood ed., 1986); Ritualized HomosexUality in Melanesia (Gilbert H. Herdt ed., 1984).

248. See John Finnis, Law, Morality, and "Sexual Orientation," 69 Notre Dame L. Rev. 1049 (1994). But compare Stephen Macedo, Homosexuality and the Conservative Mind, 84 Geo. L.J. 261 (1995), with Robert P. George \& Gerard V. Bradley, Marriage and the Liberal Imagination, 84 GEo. L.J. 301 (1993). 
nology they prefer, but it treated them as citizens and not alien sex fiends or presumptive criminals. This treatment was a reflection of the political progress gay people have made: Once objects of state erasure, gay people have not only survived but have become a community entitled to a place in American pluralism of which the Court is a guarantor. The fact that gay people are normal, or virtually normal, and partners in American pluralist politics surely inspired Justice Anthony Kennedy's decision to open his Evans opinion with the premise of the first Justice John Harlan's Plessy dissent: "[T]he Constitution 'neither knows nor tolerates classes among citizens." 249 What Harlan was arguing was that the polity could not long maintain an apartheid that officially denied the humanity and citizenship of a robust group, people of color. Kennedy's opinion can be read the same way: The apartheid of the closet that Hardwick ratified for gay people is as socially unproductive as racial apartheid.

Once Linda Brown refused to attend segregated schools and Rosa Parks refused to sit in the back of the bus, state-sponsored racial apartheid was doomed. Once Harry Hay and Del Martin refused to accept the law's characterization of them as criminals and psychopaths, ${ }^{250}$ a state-sponsored apartheid of the closet was doomed. Hardwick ratified antigay apartheid in a similar way that Plessy ratified racial apartheid. Resting upon the core idea of the Plessy dissent, Evans is best read as an effort to end a state-supported apartheid of the closet and to take antigay Kulturkampf off national and state regulatory agendas. This is a socially useful goal. To the extent Hardwick remains a symbol of antigay Kulturkampf because of its antigay rhetoric and biased reasoning, it is an albatross of the law.

\section{Doctrinal Anachronism?}

Hardwick contributed to a national and, indeed, international debate over whether consensual same-sex intimacy between adults should be criminalized. Learned opinion has overwhelmingly opposed the result and reasoning of Hardwick. ${ }^{251}$ This is reflected in the remarkable post-Hardwick legal developments. Hardwick has been shunned like a pariah of the law.

249. Romer v. Evans, 517 U.S. 620, 623 (quoting Plessy v. Ferguson, 163 U.S. 537, 559 (1896) (Harlan, J., dissenting)). Evans, handed down May 20, 1996, was delivered 100 years, almost to the day, after Plessy, which was delivered on May 18, 1896; probably the only reason it was not the same day was that May 18, 1996, was a Saturday.

250. These were early gay liberationists. Their story, and those of women and men like them, is told in John D'Emilio, Sexual Politics, Sexual Communities: The Making of a HomoseXual Minority in the United States, 1940-1970 (1983).

251. See Earl M. Maltz, The Prospects for a Revival of Conservative Activism in Constitutional Jurisprudence, $24 \mathrm{G}_{\mathrm{A}}$. L. REv. 629, 645-46 n.95 (1990) (citing 33 law review articles and comments critical of Bowers). The list of post-1990 critics includes openly heterosexual conservatives such as Richard Posner and Charles Fried, as well as other authors from a variety of perspectives. See sources cited supra notes 14-19. 
In the wake of Hardwick, gaylegal challenges to sodomy laws shifted from the U.S. Constitution to state constitutions and met with increasing success. In Commonwealth $v$. Wasson, ${ }^{252}$ a divided Kentucky Supreme Court invalidated its law criminalizing consensual "deviate sexual intercourse with another person of the same sex," as inconsistent with the Kentucky Constitution's right to privacy as well as an Evans-like reading of equal protection. ${ }^{253}$ Finding Hardwick's originalism "misdirected" and its assumptions ignorant, the Kentucky court applied to gay people the principle that "[i]t is not within the competency of government to invade the privacy of a citizen's life and to regulate his conduct in matters in which he alone is concerned, or to prohibit him any liberty the exercise of which will not directly injure society." 254 Montana and Tennessee have similarly nullified their same-sex only sodomy laws as inconsistent with state constitutional rights to privacy. ${ }^{255}$ Ironically, the Georgia Supreme Court invalidated its consensual sodomy law in 1998 on state constitutional privacy grounds that parallel the analysis of the Hardwick dissenters. ${ }^{256}$ Privacy claims in other states have been rejected on the ground that the parties presenting them were not engaged in noncommercial private sex between consenting adults. ${ }^{257}$

State courts have not accorded Hardwick the respect they normally give Supreme Court decisions. Even the Supreme Court itself has been wary of the decision. The joint opinion in Casey ignored Hardwick and rejected its originalist methodology for figuring the contours of the liberty protected by the Due Process Clause. "Neither the Bill of Rights nor the specific practices of States at the time of the adoption of the Fourteenth Amendment marks the outer limits of the substantive sphere of liberty which the Fourteenth Amendment protects." ${ }^{258}$ Remarkably, Chief Justice Rehnquist's opinion in Washington v. Glucksberg, ${ }^{259}$ which rejected a general due process right to die, failed to cite Hardwick, even though the opinion sought to revive Hardwick's methodology of declining to recognize a substantive due

252. 842 S.W.2d 487 (Ky. 1992).

253. Id. at $488,495-97$.

254. Id. at 494-95 (quoting Commonwealth v. Campbell, 117 S.W. 383, 385 (Ky. 1909)).

255. See Gryczan v. State, 942 P.2d 112, 125-26 (Mont. 1997); Campbell v. Sundquist, 926 S.W.2d 250, 266 (Tenn. Ct. App. 1996).

256. See Powell v. State, 510 S.E.2d 18 (Ga. 1998).

257. See Christensen v. State, 468 S.E.2d 188 (Ga. 1996); State v. Baxley, 656 So. 2d 973 (La. 1995) (public sex); State v. Gray, 413 N.W.2d 107 (Minn. 1987) (commercial sex); State v. Walsh, 713 S.W.2d 508 (Mo. 1986) (public sex; reserving state constitutional issue); State v. Lopes, 660 A.2d 707 (R.I. 1995) (forcible sex); State v. Morales, 869 S.W.2d 941 (Tex. 1994) (refusing to decide constitutional issue when parties had not engaged in prohibited homosexual conduct).

258. Planned Parenthood v. Casey, 505 U.S. 833, 848 (1992). In Michael H. v. Gerald D., 491 U.S. 110 (1989), Justice Scalia's position that the Due Process Clause protects only those practices, defined at the most specific level, that were protected against state interference in 1868, was rejected by a majority of Justices, including concurring Justice O'Connor, later an author of the joint opinion in Casey. See id. at 112, 127 n.6.

259. 521 U.S. 702 (1997). 
process right not specifically established in the common law tradition. ${ }^{260}$ Although the Court in Glucksberg unanimously rejected a general right to die, five Justices left open or seemed friendly to a "constitutionally cognizable interest in controlling the circumstances of his or her imminent death," especially to avoid pain. ${ }^{261}$

International experience supports the proposition that laws criminalizing same-sex intimacy are anachronistic for modern urbanized societies. Virtually all the countries with laws against consensual sodomy are nonindustrialized societies. ${ }^{262}$ Japan, Hong Kong, China, Taiwan, South Korea, Canada, Mexico, Brazil, Argentina, Columbia, Venezuela, and most of the states in Europe have no consensual sodomy laws. The few straggler countries or provinces have been subjected to legal as well as political pressure to abandon laws that are anachronistic for modern urbanized societies that have sizeable gay populations. In Dudgeon v. United Kingdom, ${ }^{263}$ the European Court of Human Rights ruled that Northern Ireland's consensual sodomy prohibition contravened the right to privacy set forth in Article 8 of the European Convention on Human Rights. The Court subsequently applied Dudgeon to declare the sodomy laws of Ireland and Cyprus similarly in derogation of the Convention, thereby completing a clean sweep of such regulations in the European Community (EC). ${ }^{264}$ The Constitutional Court of South Africa invalidated its sodomy and unnatural relations laws in 1998 on grounds of privacy and in an opinion well worth study. ${ }^{265}$

Like the United States, Australia is a federal system composed of several states. After Hardwick, only one state in Australia, Tasmania, continued to proscribe private, consensual sex between adult men. In 1992, the Human Rights Commissioner in Australia asked the federal government to override Tasmania's law. The Commissioner found that the Tasmanian law clearly breached Australia's obligations under the International Covenant on Civil and Political Rights [ICCPR] by failing to provide homosexuals equality under the law and for breaching their right to privacy. Upon petition of the Tasmanian Gay and

260. See id. at 719-24. The Court returned to a Casey-like, evolving history approach to privacy in County of Sacramento v. Lewis, 118 S. Ct. 1708 (1998).

261. Glucksberg, 521 U.S. at 736-38 (O'Connor, J., concurring); see also id. at 738-52 (Stevens, J., concurring in the judgment); $i d$. at $721-36$ (Souter, J., concurring in the judgment); $i d$. at 789 (Ginsburg, J., concurring in the judgment); $i d$. at 789-92 (Breyer, J., concurring in the judgment).

262. See James D. Wilets, International Human Rights Law and Sexual Orientation, 18 Hastings INT'L \& Comp. L. Rev. 1, 64-66 (1994); see also Rob Tielmon \& Hans Hammelburg, World Survey on the Social and Legal Positions of Gays and Lesbians, in THE THIRD Pink BOOK: A Global View of Lesbian and Gay Liberation and Oppression 249-342 (Aart Hendriks et al. eds., 1993) (country-by-country review).

263. 45 Eur. Ct. H.R. (ser. A) at 25 (1981).

264. See Modinos v. Cyprus, 259 Eur. Ct. H.R. (ser. A) at 10-11 (1993); Norris v. Ireland, 142 Eur. Ct. H.R. (ser. A) at 17-18 (1988).

265. See Highest Court Strikes Down Laws Banning Homosexual Relations in South Africa, L.A. Times, Oct. 10, 1998, at A3. 
Lesbian Rights Group, the United Nations Human Rights Committee, in Toonen $v$. Australia ${ }^{266}$ ruled that Tasmania's policy violated article $17(1)$ of the ICCPR, which protects against "arbitrary or unlawful interference with his privacy, family, home or correspondence, nor to unlawful attacks on his honour and reputation." 267 Tasmania complied by repealing its consensual sodomy law in $1997 .{ }^{268}$

Toonen is of special significance, because the United States has also signed and ratified the ICCPR. ${ }^{269}$ Thus, the United States has accepted international obligations under the Covenant, although it has not made itself amenable to international adjudication of grievances before the Human Rights Committee, nor is the treaty self-executing in American courts. On the other hand, the United States has expressed a readiness to take such "measures as may be necessary to ensure that the States of the Union implement the rights guaranteed by the Covenant." 270 After Toonen, the Committee expressed specific concern "at the serious infringement of private life in some States [of the United States] which classify as a criminal offence sexual relations between consenting adult partners of the same sex carried out in private."271 The ICCPR would not alone justify the Supreme Court's overruling of Hardwick, but the international obligation created in the wake of Toonen ought to be considered by the Court when it interprets domestic law, including constitutional law. ${ }^{272}$ Additionally, Toonen and the post-Dudgeon EC decisions are subsequent developments that support a reconsideration of precedent and, more pointedly, that highlight the anachronistic quality of Hardwick's rule and its reasoning.

266. U.N. GAOR, Hum. Rts. Comm., 50th sess., 448th mtg., U.N. Doc. CCPR/C/50/D/488/ 1992 (1994).

267. International Covenant on Civil and Political Rights, G.A. Res. 2200A, U.N. GAOR, 21st Sess., Supp. No. 16 at 55, U.N. Doc. A/6316 (1966).

268. See Tasman Sodomy Laws Repealed, INDEPENDENT (London), Apr. 17, 1997, at 14.

269. See International Covenant on Civil and Political Rights, Mar. 23, 1976, 999 U.N.T.S. $171,172$.

270. Consideration of Reports Submitted by States Parties Under Article 40 of the Covenant, U.N. GAOR, Hum. Rts. Comm., 53d Sess., II 9, U.N. Doc. CCPR/C/79/Add. 50 (1995).

271. Id. II 22.

272. Cf. Washington v. Glucksberg, 521 U.S. 702, 718-19 n.16 (1997) (considering legal rules followed in other industrialized countries before deciding not to recognize a general "right to die"). American courts are supposed to interpret federal law to be consistent with America's international commitments and customary international law, even if they are not otherwise judicially enforceable. See Murray v. Schooner Charming Betsy, 6 U.S. (2 Cranch) 64, 118 (1804) (Marshall, C.J.); Restatement (Third) of the Foreign Relations Law of the United STATES $\$ 114$ (1987). Non-self-executing treaties "may sometimes be held to be federal policy superseding State law or policy." Id. $\S 115 \mathrm{cmt}$. (e); see also Toll v. Moreno, 458 U.S. 1 (1982). For an argument that Toonen more directly requires overruling Hardwick, see James D. Wilets, Using International Law to Vindicate the Civil Rights of Gays and Lesbians in United States Courts, 27 Colum. Hum. Rts. L. Rev. 33 (1995). 


\section{Public Reliance on Hardwick?}

Although Hardwick is a recent precedent, the sodomy laws it ratified existed long before and had been slanted by a Hardwick-like homophobia for decades. Most openly antihomosexual policies supported by sodomy laws (such as exclusions of gay people from the civil service) have been rescinded, but certain policies might be unsettled if Hardwick were to be overruled. Police policies in some jurisdictions, mostly in the South, would have to be rethought. Could local vice squads arrest people for having sex in public toilets, automobiles, erotic nightclubs, or adult bookstores? For soliciting decoy cops for private sex? In all these situations, right of privacy challenges have sometimes been successful in state courts. ${ }^{273}$ The most important national policy that would be unsettled by overruling Hardwick is the armed forces' exclusion of lesbian, gay, and bisexual personnel. The exclusion is defended in part as a corollary to the military's criminal prohibition of sodomy. Gay soldiers can be excluded either because they commit sodomy, or because they have a "propensity" to commit sodomy. ${ }^{274}$ If Hardwick were overruled, the consensual sodomy prohibition in the Uniform Code of Military Justice (UCMJ) would be more vulnerable to constitutional attack. Because the Supreme Court strongly defers to military statutes and regulations that would be invalid if adopted in a civilian context or by the states, ${ }^{275}$ the UCMJ's unconstitutionality would not be a foregone conclusion, however. (One possible resolution would be for the Court to allow the armed forces to prohibit sodomy on military premises but not in soldiers' homes or off-base.) Nonetheless, the sodomy prohibition would be more vulnerable without Hardwick, and if the sodomy prohibition fell there would be fewer arguments left to the defenders of the military exclusion of gay people. On the other hand, the military's propensity argument might be questioned even if the armed forces could criminalize consensual sodomy. ${ }^{276}$

Although overruling Hardwick could unsettle some policies, many of the issues identified above could be stabilized by a cautious approach to an overruling, such as letting Hardwick bleed for several years and then overruling it, or even just ignoring it. More important,

273. See People v. Triggs, 506 P.2d 232 (Cal. 1973) (public toilet); Commonwealth v. Wasson, 842 S.W.2d 487 (Ky. 1992) (solicitation of decoy cop); People v. Dezek, 308 N.W.2d 652 (Mich. App. 1981) (public toilet); People v. Uplinger, 447 N.E.2d 62 (N.Y. 1983) (solicitation); People v. Onofre, 415 N.E.2d 936 (N.Y. 1980) (automobile); Commonwealth v. Bonadio, 415 A.2d 47 (Pa. 1980) (erotic club); Honeycutt v. State, 690 S.W.2d 64 (Tex. Crim. App. 1985) (automobiles); Leibman v. State, 652 S.W.2d 942 (Tex. Crim. App. 1983) (adult bookstore).

274. See Able v. United States, 88 F.3d 1280 (2d Cir. 1996) (discussing the new policy); Thomasson v. Perry, 80 F.3d 915 (4th Cir. 1996) (en banc) (same).

275. See, e.g., Rostker v. Goldberg, 453 U.S. 37 (1981).

276. See generally David Cole \& William N. Eskridge, Jr., From Hand-Holding to Sodomy: First Amendment Protection of Homosexual (Expressive) Conduct, 29 Harv. C.R.-C.L. L. REv. 319 (1994). 
the policies that would be most unsettled are among the least defensible. Toilet stakeouts and decoy operations, for example, are a lavish deployment of scarce police resources in cities with high rates of violent crime. Most important, overruling Hardwick would have potentially affirmative effects on public policy discourse. Consider a few.

\section{a. Mutuality as the Prerequisite to Sexual Intimacy}

A criticism of Hardwick, offered above, is that it aligns the symbolic power of law with the wrong normative regime. When Hardwick emphasized an antihomosexual policy for sodomy laws, it not only chose an unproductive policy, but the Court missed an opportunity to stress a productive policy. The norm for sexual intimacy that has been advanced by feminist and gaylegal theory is mutuality: sex is good and normal when the participants welcome it, when the sex is truly a joint enterprise meeting the needs of the partners. ${ }^{277} \mathrm{~A}$ danger posed by Hardwick is the suggestion to men that their intercourse with women is validated, in part, by the mere fact of its heterosexuality. This partial validation threatens to deflect attention from the mutuality goal.

This criticism of Hardwick should be tempered by the realization that sodomy law has long been moving toward a regime of mutuality. All the states now regulate "forcible" sodomy, and "ordinary" sodomy prosecutions since 1969 have usually involved situations where the sex is alleged to be unwelcome. ${ }^{278}$ For example, in Schochet $v$. State, ${ }^{279}$ the defendant was accused of raping and sodomizing a woman he met at a bar; he admitted to oral and penile-vaginal sex with her but claimed it was consensual. The jury acquitted Schochet of all rape and forcible sodomy charges and convicted him only of consensual sodomy. ${ }^{280}$ The Maryland Court of Appeals overturned that conviction by interpreting its sodomy law to exclude consensual heterosexual sodomy. ${ }^{281}$ On the one hand, prosecutors use sodomy laws in rape cases to enhance the odds that the defendant will be convicted of something even if the jury disbelieves the complaining witness's testimony that she was coerced. Given the difficulty of winning convictions in cases of "real rape," this may not seem unjust. On the other hand, this strategy might make it too easy for juries to escape the difficult issues of consent and settle on sodomy as an acceptable compromise, and might make it too easy for a jury to imprison a person who in fact was falsely accused of rape.

277. See generally Larry Catá Backer, Raping Sodomy and Sodomizing Rape: A Morality Tale About the Transformation of Modern Sodomy Jurisprudence, 21 AM. J. CRIM. L. 37 (1993); Martha Chamallas, Consent, Equality, and the Legal Control of Sexual Conduct, 61 S. CAL. L. REv. 777 (1988).

278. See Backer, supra note 277 , at $95-118$ (discussing merger of sodomy and rape).

279. 580 A.2d 176 (Md. 1990).

280. See id. at 180.

281. See id. at 186; accord Post v. State, 715 P.2d 1105 (Okla. Crim. App. 1986). 


\section{b. Preventing the Spread of HIV}

One of the amicus briefs filed in Hardwick argued that sodomy laws are justified as a way to prevent the spread of HIV, the virus that causes AIDS. ${ }^{282}$ The Supreme Court correctly ignored the argument. Anal sex can and does transmit HIV, just as penile-vaginal sex can and does transmit HIV - but oral sex (now considered sodomy) does not as clearly or easily transmit HIV. Moreover, prohibiting oral sex contributes little if anything to slowing the public health menace called AIDS. The act (anal versus penile-vaginal sex) is not so important in transmission as the failure to use a condom correctly. By focusing attention on the sexual act rather than on the safety of the sex, sodomy laws divert attention from the most productive way to fight the disease-education about the risks of all kinds of sex and about the utility of safer sex techniques. Sodomy laws may even be counterproductive, as when they are invoked to oppose public school sex and AIDS education and condom distribution programs. Public health experts believe education and condom distribution are the best ways to fight AIDS. ${ }^{283}$ Thus far, there is no empirical evidence that such measures increase the sexual activity that sodomy laws prohibit. ${ }^{284}$

Even if sodomy rather than unsafe sex contributed decisively to the spread of HIV, laws prohibiting sodomy would not necessarily help fight the disease. Ever since the Kinsey group reported that ninety-five percent of American men had violated one or more of the popular sex laws, including sodomy laws, it has been unclear whether sex laws substantially and predictably deter the conduct they forbid. Not only is the risk of detection minuscule (and therefore the deterrence value nil), but the forbidden zone created by consensual sex laws helps create lines that make the forbidden fruit all that much sweeter. The primary deterrent effect of consensual sodomy laws is to keep sex in the closet, hidden and underground, precisely the terrain that bred and spread HIV in the late 1970s and early 1980s. Many public health professionals believe that sodomy laws modestly impede AIDS programs by discouraging people from being tested for the virus or treated for the disease, and by pushing prohibited sex into dark corners unilluminated by education and safer sex guidelines. ${ }^{285}$

282. See Brief of David Robinson, Jr., as Amicus Curiae in Support of Petitioners, Bowers v. Hardwick, 478 U.S. 186 (1986) (No. 85-140), microformed on CIS U.S. Supreme Court Records and Briefs, No. 85-140-5 (Congressional Info. Serv.).

283. See AIDS IN THE IndUSTRIALIZed Democracies 33-36 (David Karp \& Ronald Bayer eds., 1992).

284. See generally Ralph Hingson et al., Acquired Immunodeficiency Syndrome Transmission: Changes in Knowledge and Behaviors Among Teenagers, Massachusetts Statewide Surveys 1986 to 1988, 85 Pediatrics 24 (1990).

285. See Campbell v. Sundquist, 926 S.W.2d 250, 263-64 (Tenn. Ct. App. 1996); Tomas J. Philipson \& Richard A. Posner, Private Choices and Public Health: The Aids Epidemic in an Economic Perspective 148 (1993). The amicus brief of the American Public Health Association argued that, due to fear of sodomy prosecution, some people do not report 


\section{c. Eroding the Act $=$ Status Argument}

As Janet Halley has said, sodomy is the metonym for the homosexual. ${ }^{286}$ Homosexual identity is defined by presumptions about homosexual conduct. Because Hardwick ratifies state prohibition of homosexual conduct, it is regularly, albeit decreasingly, invoked as a basis for denying gay people equal treatment. According to the Virginia Supreme Court, "[c]onduct inherent in lesbianism is punishable as a ... felony," and that is an "important consideration in determining custody" of a woman's biological child. ${ }^{287}$ The state court debate in child custody and adoption cases has spilled over into the federal cases evaluating the military exclusion of gays. Judicial rulings discriminating against gay litigants regularly deny they are discriminating based on sexual orientation. Citing Hardwick, they can plausibly say they are merely regulating problematic conduct. ${ }^{288}$ At a more abstract level, opponents of gay rights reject analogies to race or sex or even religious discrimination on the ground that antigay discrimination is based on conduct rather than status.

Perhaps this is no longer true. Evans is the antonym of Hardwick. Judges are no longer constrained by Hardwick in equal protection cases and can follow Evans's lead if they choose to do so. But judges desiring to reject challenges to antigay policies can follow Hardwick and limit Evans to its unusual facts. This lack of authoritative guidance is not a terrible state of affairs and is probably what the Supreme Court expected after Evans: State courts and lower federal courts will struggle with issues of sexual orientation discrimination on a case-by-case basis, less constrained by Supreme Court precedent because of the Hardwick-versus-Evans choice now available. At some point, however, the Supreme Court will have to choose: Hardwick? Or Evans?

\section{Larger Historiographical Lessons: Original Intent and Constitutional Interpretation}

The premise of Justice White's opinion in Hardwick was that the Court should be chary of creating new constitutional rights unless supported by the original intent of those who framed the Constitution or, in the case at hand, the Fourteenth Amendment. The foregoing historiography illustrates problems with original intent as a method of constitutional interpretation and provides a response to the most plausible defense to originalism as a governing methodology.

or seek medical treatment for venereal disease infection, while others are reluctant to be tested to determine if they are infected. See id.

286. See Halley, supra note 13 , at 1737.

287. Bottoms v. Bottoms, 457 S.E.2d 102, 108 (Va. 1995).

288. See the debate between Judges Silberman and Wald in Steffan v. Perry, 41 F.3d 677 (D.C. Cir. 1994) (en banc), and between Judges Norris and Reinhardt in Watkins v. U.S. Army, 847 F.2d 1329 (9th Cir. 1988), vacated, 875 F.2d 699 (9th Cir. 1989) (en banc). 
The main problems with originalism ${ }^{289}$ are well illustrated by my critique of Hardwick. Although the defenders of originalism claim that it is more objective than other methods of interpretation and therefore better constrains interpreters, Hardwick illustrates the slipperiness of originalism. Justice White's insistence that only "homosexual sodomy" was at issue was driven by his desire to distance the case before him from the contraception and abortion cases, but Justice White then posed the historical question in impossibly anachronistic terms. His originalist approach to the right of privacy in this particular case was in stark contrast to his own and the Court's nonoriginalist approach to the right of privacy in the contraception cases, to the Court's nonoriginalist approach to the right of privacy in the post-Roe $v$. Wade abortion cases, and to his strongly dynamic approach to sodomy laws in Hardwick itself. The behind-the-scenes reports suggest that original intent was just a cover story for a decision made on other grounds.

The biggest problem for originalism is the indeterminate nature of an originalist inquiry into an old text. Applying an old text to unforeseen circumstances is an intrinsically difficult endeavor, dramatically illustrated by the case of "homosexual sodomy." Although Justice White correctly observed that most states had sodomy laws in 1868, when the Fourteenth Amendment was adopted, and about half still had them in 1986, when Hardwick was decided, that historical continuity masked changes that affected every other feature of the constitutional question:

(1) What was it that sodomy laws prohibited? In 1868 , the common law refused to say much about what was a "crime against nature"-except that it did not include oral sex. In 1986 , oral sex was synonymous with sodomy.

(2) What goal(s) did sodomy laws serve? In 1868, the main goal was state insistence that sex be within the institution of procreative marriage. By 1986, that goal was not one the state could constitutionally pursue.

(3) What was the relationship between sodomy and homosexuality? In 1868, there was no English-language term for samesex attraction. By 1986, homosexuality had become a culturally totalizing term.

Because the issue before the Court in Hardwick was so different from the issues debated in the Reconstruction era, there was not even an objective or neutral way to frame the interpretive question.

289. See John Hart Ely, Democracy and Distrust (1980); Paul Brest, The Misconceived Quest for the Original Understanding, 60 B.U. L. REv. 204, $205-09$ (1980); Daniel A. Farber, The Originalism Debate: A Guide for the Perplexed, 49 OHIо ST. L.J. 1085; Mark J. Tushnet, Following the Rules Laid Down: A Critique of Interpretivism and Neutral Principles, 96 HARV. L. REV. 781 (1983). 
There are some ways of framing the question that are less neutral than others, however. The exemplar of nonneutrality is the way Justice White set the originalist inquiry: Would the Framers have considered homosexual sodomy a protected activity? A more neutral originalist inquiry would have been something closer to the following: If the Framers had been asked about oral sex between two men in a private home, would they have understood that to be protected from state police intrusion? There is substantial evidence that people in the 1860 s would have answered "yes" to that question, but they might have answered "no" to this variation: If the Framers had been asked about oral sex between two men in a private home, would they have understood such conduct to receive affirmative protection from the constitutional amendment they were drafting?

To be true to a reconstructive inquiry, however, the question would have to be more complex, such as the following: If the Framers could have foreseen that colonies of men would form in the nation's cities, for the purpose of engaging in oral sex and masturbation with one another, renouncing marriage and their natural gender role, would they have wanted this conduct protected from police regulation once the communities became alarmed? Put that way, the Framers might have said "no," but another way of putting the complex question could just as well trigger a "yes": If the Framers could have foreseen that laws prohibiting contraception and abortion would be held to violate the amendment they drafted, because the amendment was construed to encode a right to sexual privacy, would the Framers have felt that oral sex between consenting adults in the privacy of their home was distinguishable? And so on.

The argument for originalism is neither its objectivity nor its constraint-for originalism has neither quality-but is instead its conservatism. If the burden of persuasion rests with the party asserting a constitutional right, originalism makes it harder to recognize new rights or expand recognized rights to new situations. (Of course, any constitutional methodology can start with this kind of conservative presumption against judicial invalidation.) Indeed, that is surely what Justice White had in mind when he warned that the Court's legitimacy is most in peril when it expands nontextual constitutional rights, like privacy, without support in the Framers' original expectations. Yet it was Justice White's originalist opinion that landed the Court into legitimacy trouble. The reason has to do with another critique of originalism: its insistence that law is only a matter of vertical coherence (this interpretation is consistent with all that came before), with no theoretical room for horizontal coherence (this interpretation is consistent with other rights and rules today).

Originalism's limitation as a legitimating methodology can be illustrated by the privacy cases themselves. Buck v. Bell-Justice Holmes's snarly opinion accepting the constitutionality of forced ster- 
ilization-was an opinion perfectly supportable by a vertical understanding of constitutional law: Show me where there is a right to sexual satisfaction in the Constitution or its contemporary understanding, and I'll recognize your right to be free from state interference. But Holmes's position could not long survive the knowledge that Nazi Germany deployed the same eugenic philosophy adopted in Virginia to commit unspeakable human experimentation, nor could it have survived Stephen Jay Gould's revelation decades later that Carrie Buck, the woman Virginia sterilized, was not mentally disabled, as the state claimed. ${ }^{290}$ Constitutional law has a learning curve, and it must include horizontal as well as vertical considerations if it is to remain the foundation of government's overall legitimacy. If the Constitution's protection of "life, liberty, and property" does not assure protection for productive mutual sexual expression between consenting adults, what meaning can due process possibly have for proper governance? This was the question that sunk Judge Bork, and it may ultimately sink Hardwick.

A principle arising from the Court's privacy cases involves not just the ability of an individual to control her or his body, but also involves the state's obligation to allow him space for individual and relational development. ${ }^{291}$ Since the Skinner decision, which effectively overruled Buck v. Bell, that development has included sexual development, a precept that would have been anathema to the Framers of the Fourteenth Amendment, but which to twentieth-century post-Freudian culture is just as important as the property rights, right to earn a living, and contract rights valued by the Framers. These values implicate horizontal pressures that weigh on the Court to overrule or limit Hardwick.

Another horizontal development is the expansion of American democracy. Only men voted on the Fourteenth Amendment, which in turn is the only explicitly male-privileged provision of the Constitution. Who can deny today that women are equal citizens? A principle arising from the Court's sex discrimination cases is that women must share equally in the space and the opportunities, tailored in the case of pregnancy to women's particular needs. ${ }^{292}$ Women's equality as citizens - a proposition not accepted by the Framers but one now necessary to the legitimacy of our government-strongly supports the extension of privacy rights to reproductive liberties such as contraception and abortion (generally prohibited in the Reconstruction Era). What women gained after World War II, gay people are now gaining after Stonewall-a place at the table of American pluralism. Romer v. Evans suggests that gay people cannot be segregated off from privacy

290. See Gould, supra note 35 , at 336.

291. See Rubenfeld, supra note 18 , at 744-47.

292. See Anita L. Allen, Uneasy Access: Privacy for Women in a Free Society 8388 (1988). 
protections any more than women can be. A healthy pluralism that includes lesbian, bisexual, and gay people as citizens is not one that can tolerate the antihomosexual rhetoric of Bowers $v$. Hardwick, nor one that should perpetuate the holding of an originalist decision so illgrounded in the historiography of the founding.periods. 


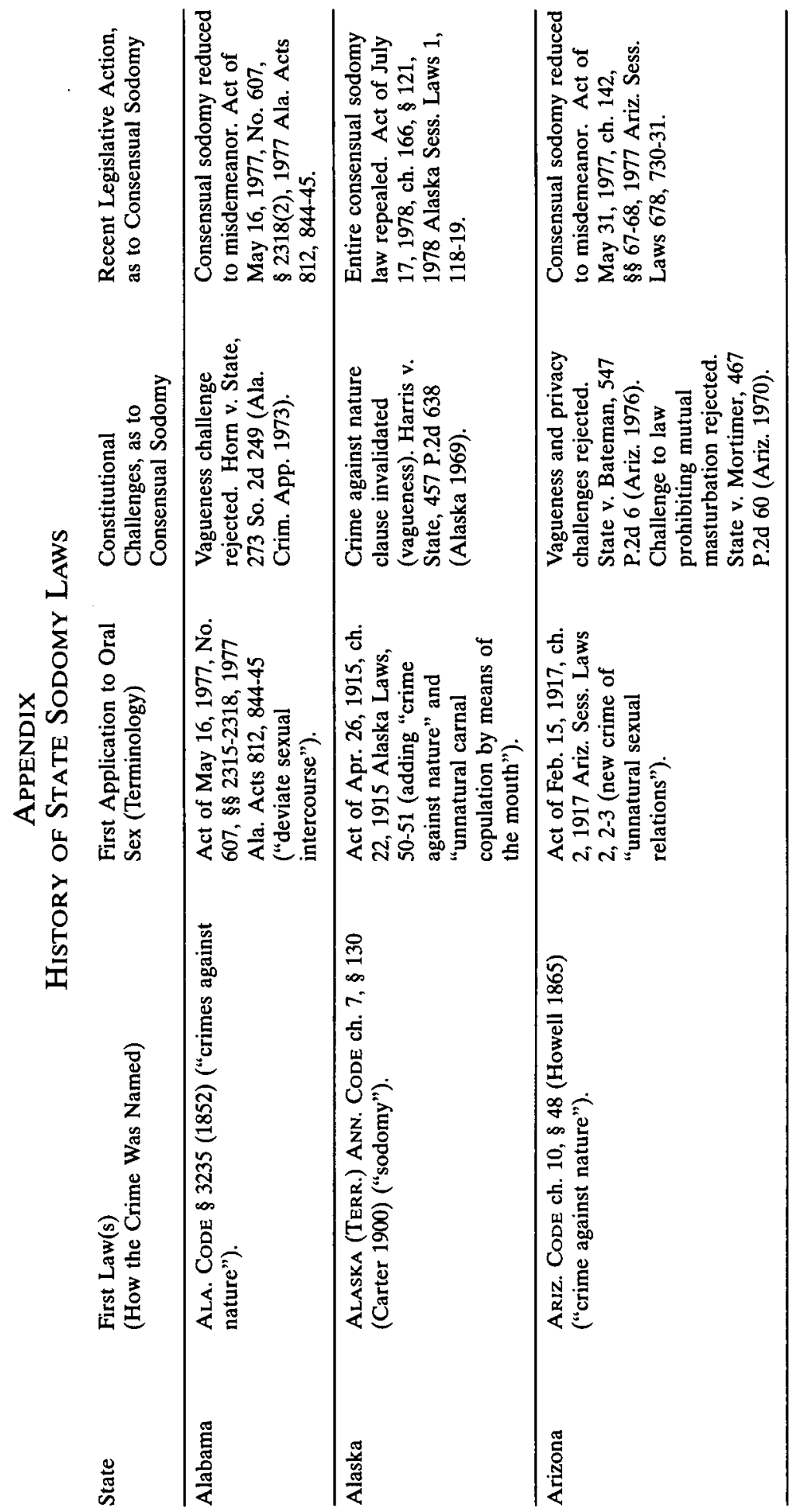




\begin{tabular}{|c|c|c|c|}
\hline 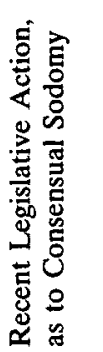 & 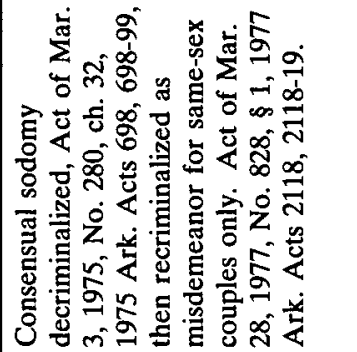 & 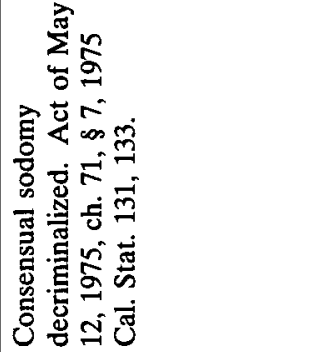 & 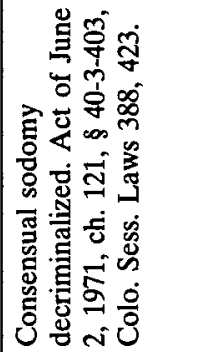 \\
\hline 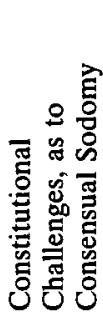 & 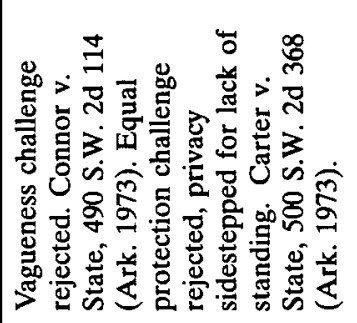 & 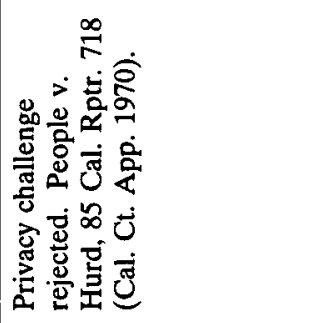 & 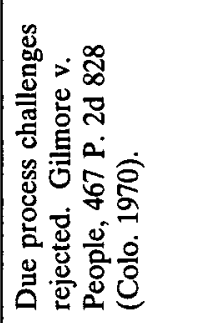 \\
\hline 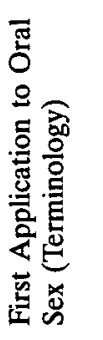 & 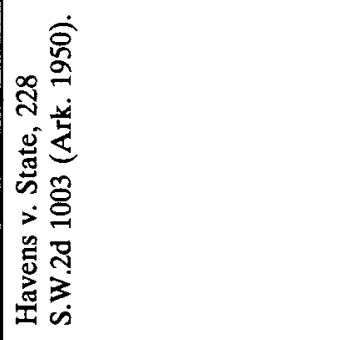 & 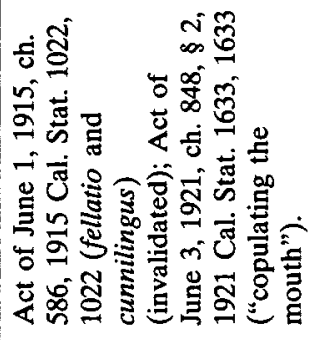 & 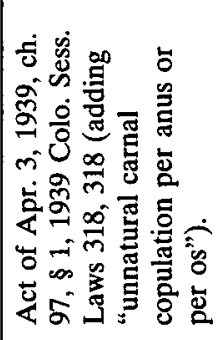 \\
\hline 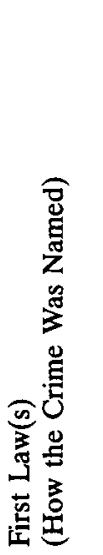 &  & 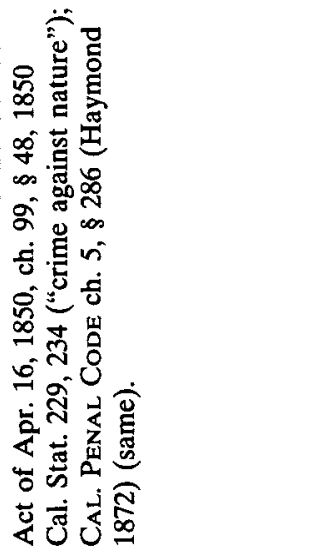 & 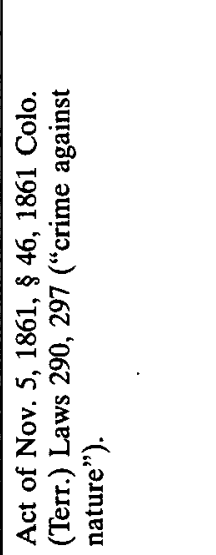 \\
\hline 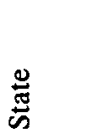 & 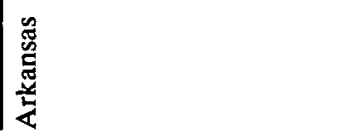 & 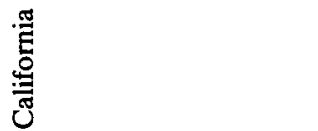 & 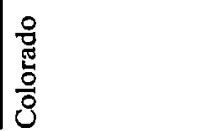 \\
\hline
\end{tabular}




\begin{tabular}{|c|c|c|c|}
\hline 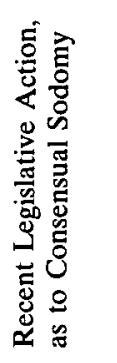 & 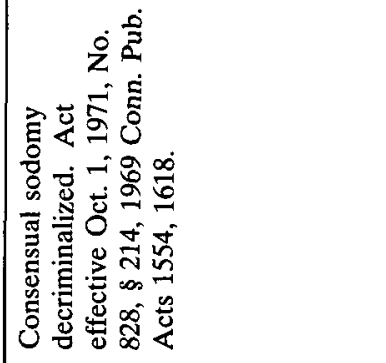 & 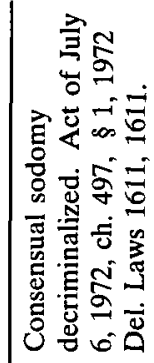 & 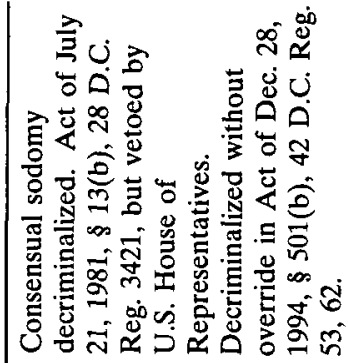 \\
\hline 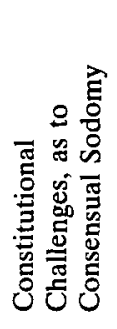 & 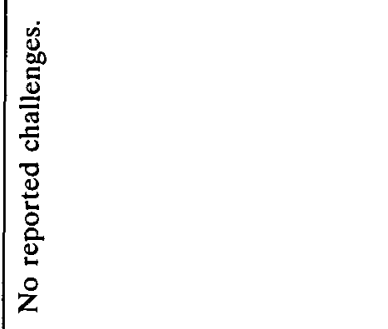 & 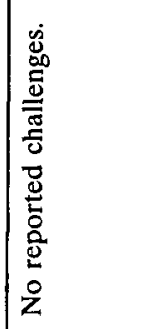 & 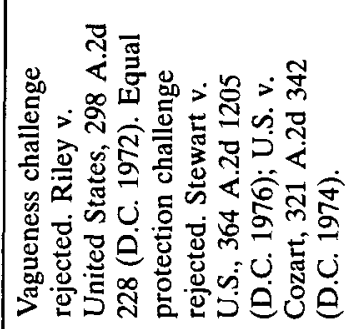 \\
\hline 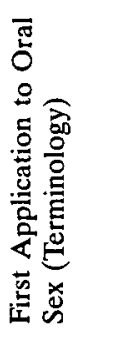 & 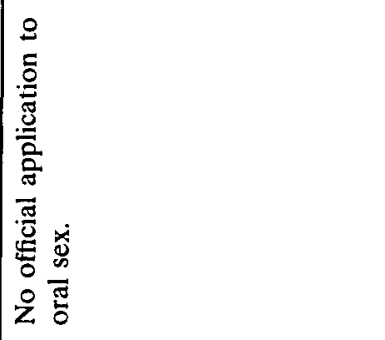 & 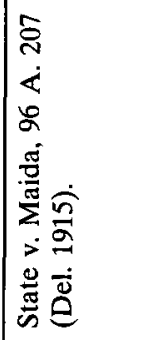 & 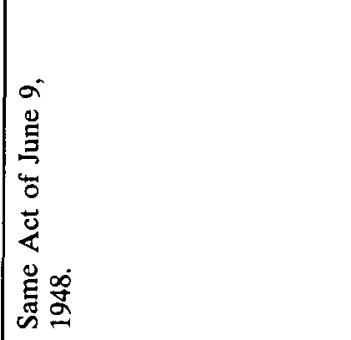 \\
\hline 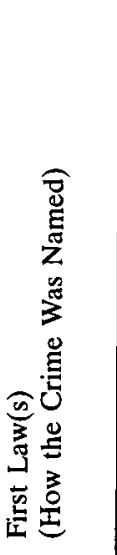 & 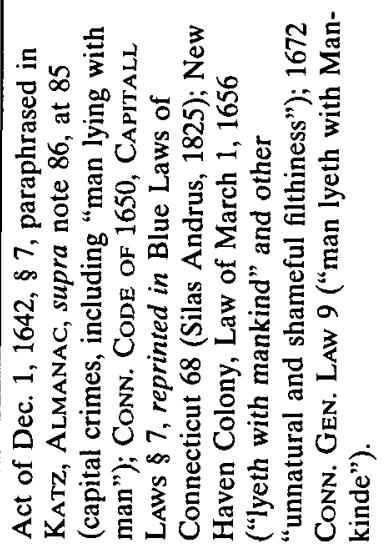 & 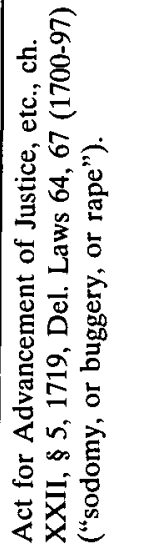 & 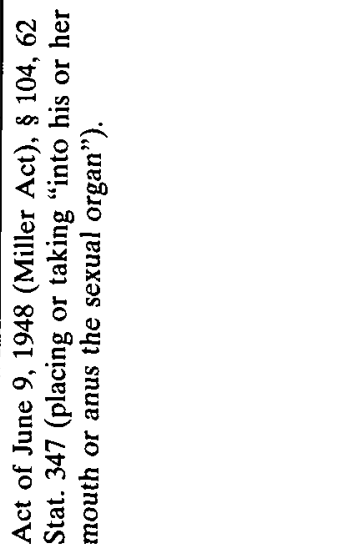 \\
\hline & 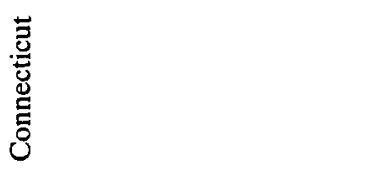 & 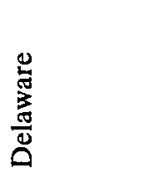 & 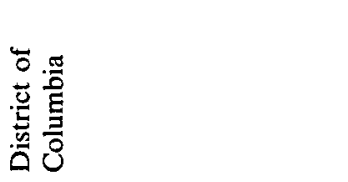 \\
\hline
\end{tabular}



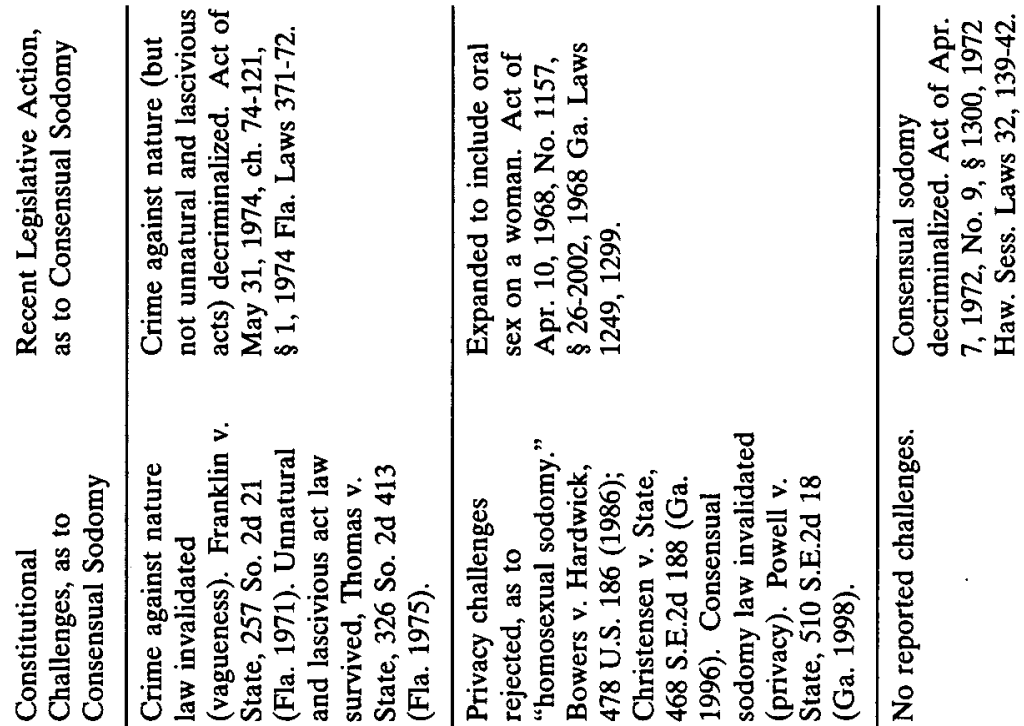

च

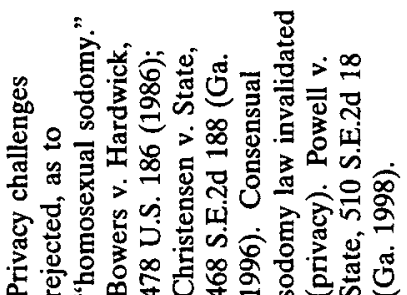

政

山่

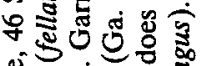

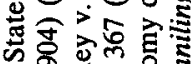

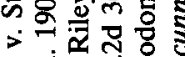

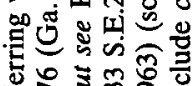

语总

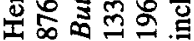

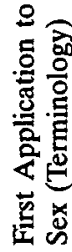

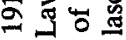

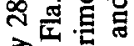

运专雪
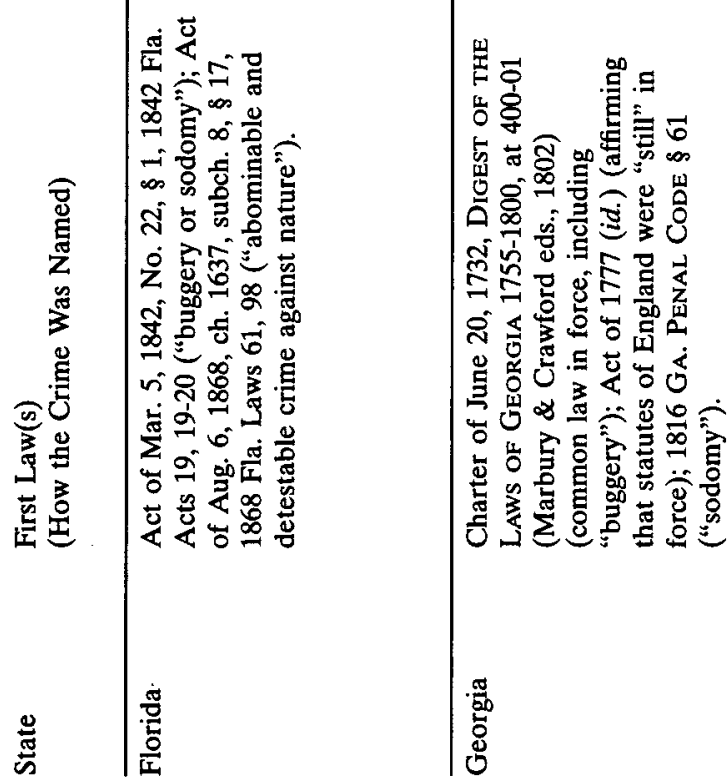

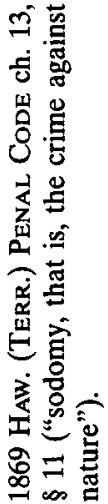

: 


\begin{tabular}{|c|c|c|c|c|}
\hline 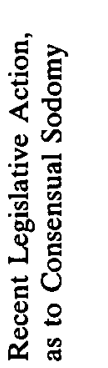 & 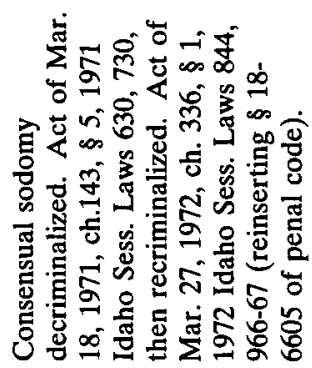 & 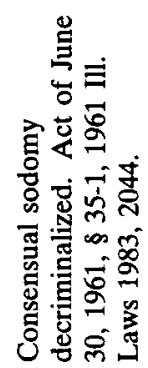 & 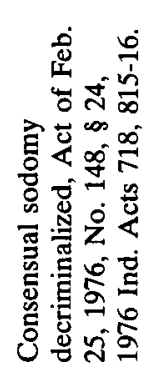 & 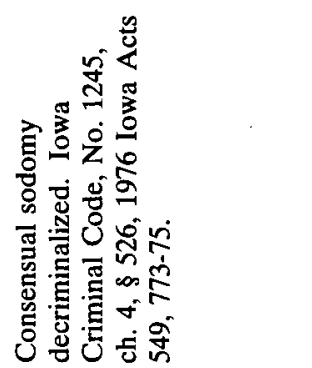 \\
\hline 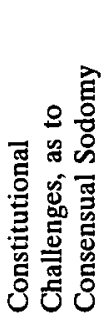 & 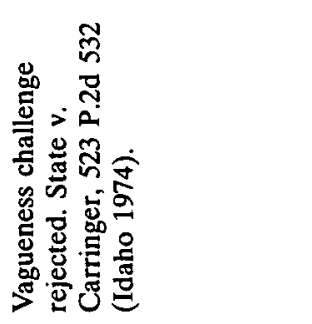 & 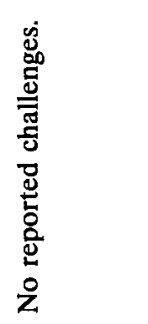 & 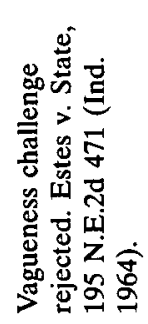 & 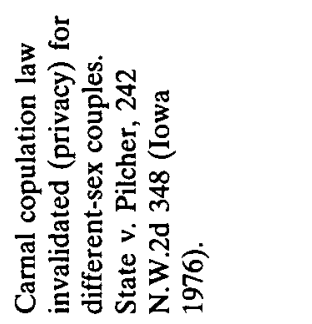 \\
\hline 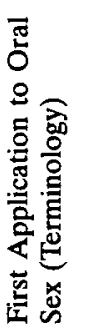 & 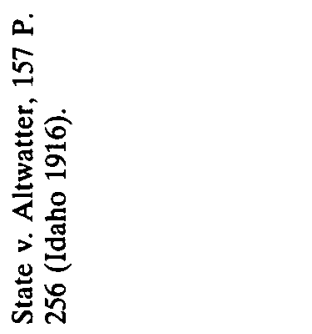 & 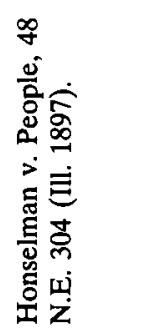 & 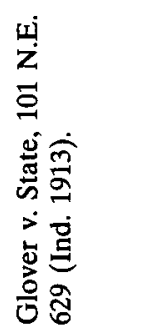 & 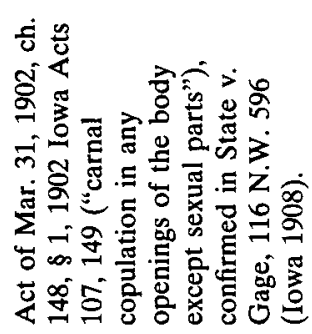 \\
\hline 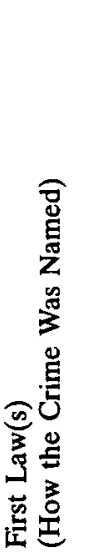 & 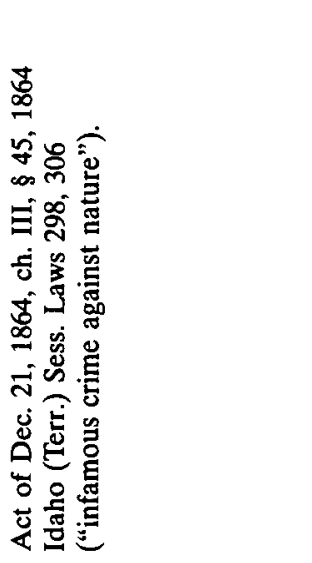 & 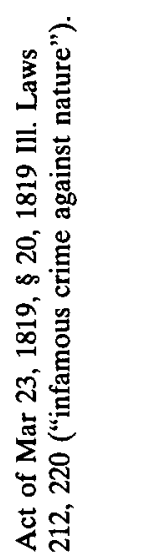 & 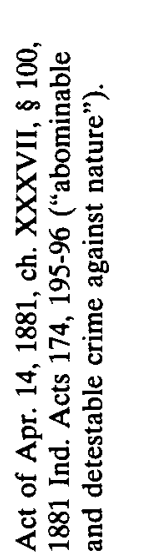 & 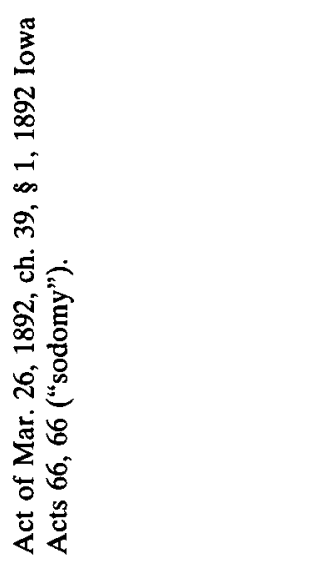 \\
\hline 9 & $\frac{\stackrel{2}{\tilde{n}}}{\text { d }}$ & $\begin{array}{l}\text { 吕 } \\
\text { 葛 }\end{array}$ & 㺃 & $\tilde{z}$ \\
\hline
\end{tabular}




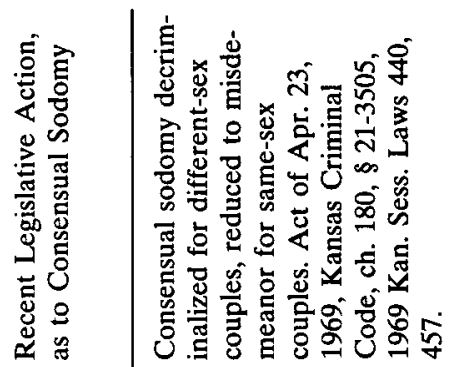

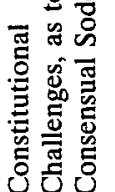

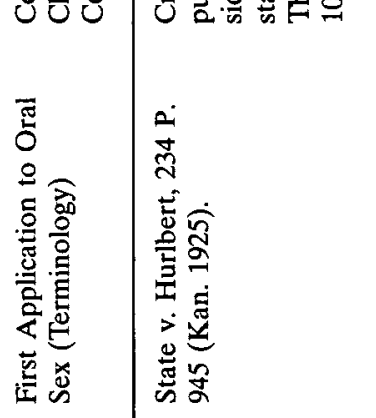

离
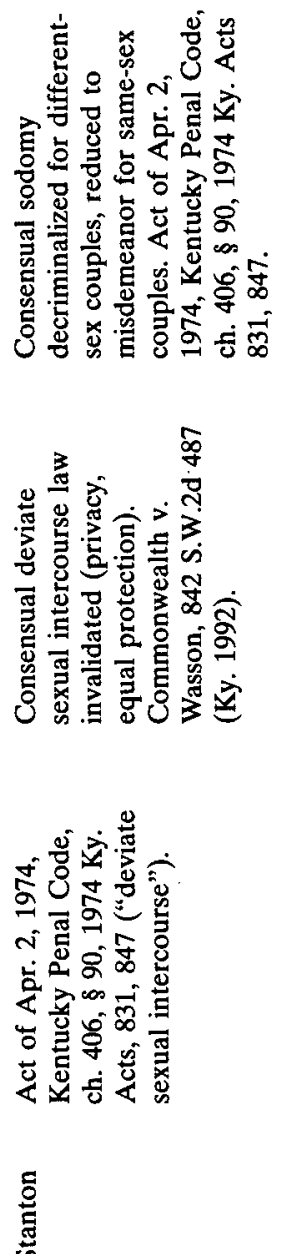

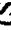

$=$

$\dot{\nabla}$

范哭

$\infty$

起 b

它

s

空道

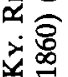

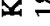

홀

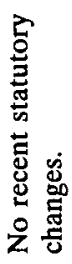

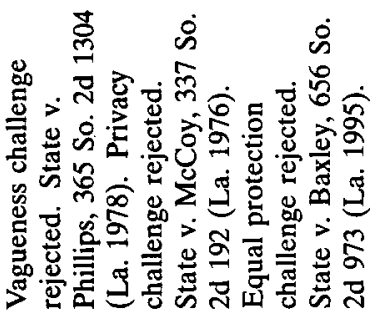

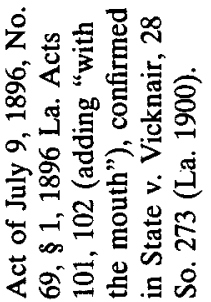

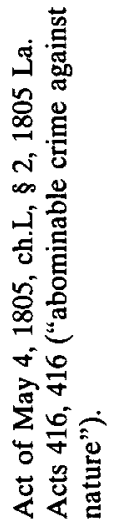

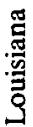




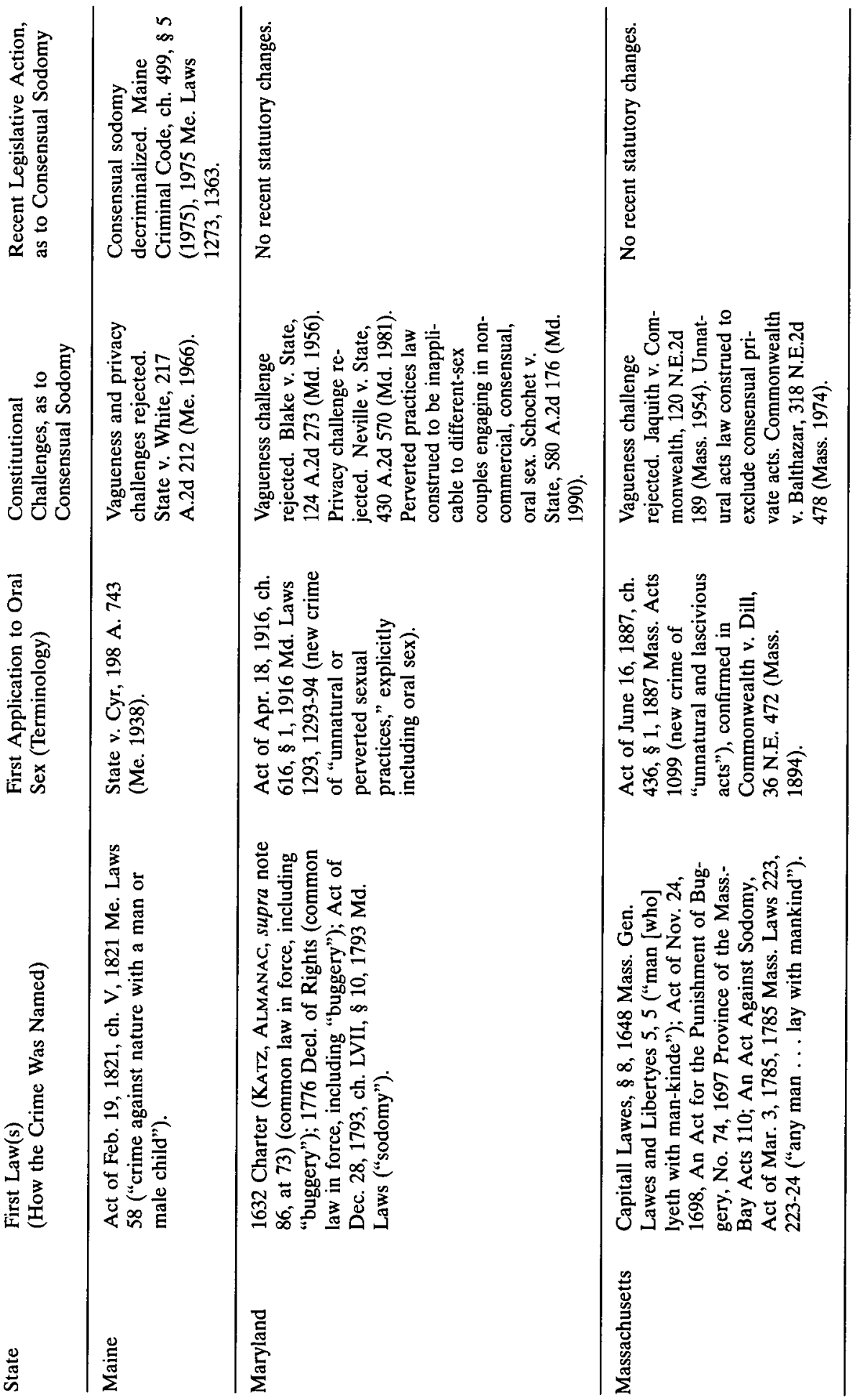




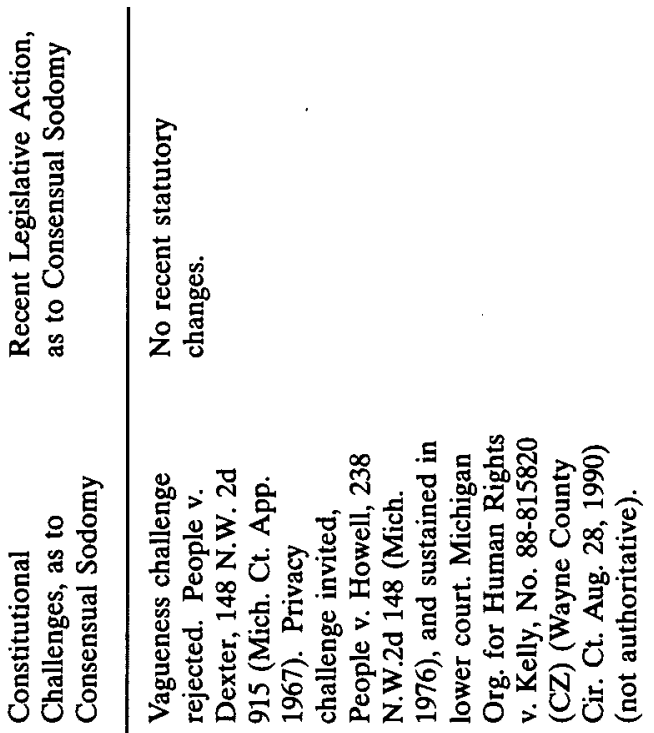

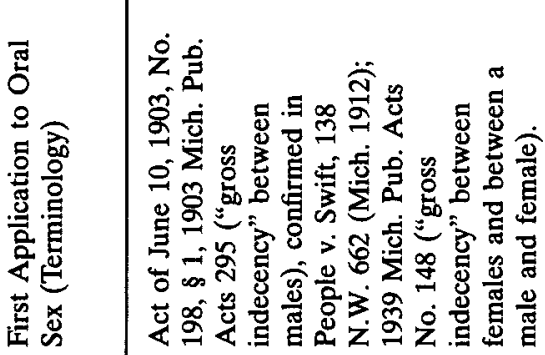

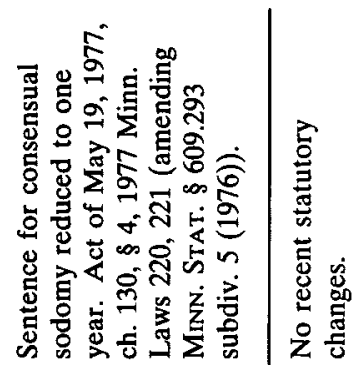

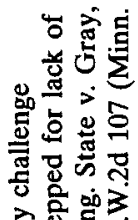

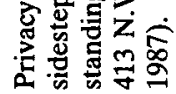

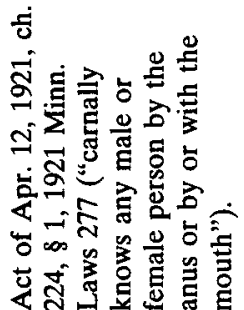

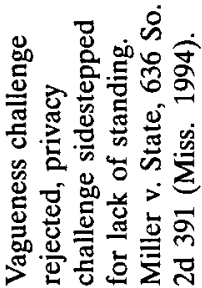

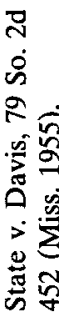

호몸

戠产

氜产

E要要

웡.

की

$\propto$

的音

造密

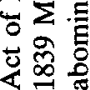

产 


\begin{tabular}{|c|c|c|c|}
\hline 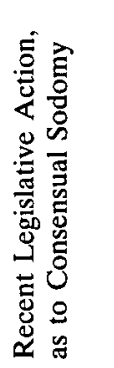 & 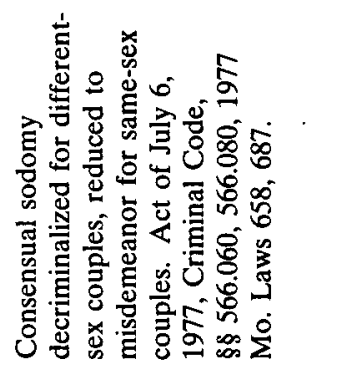 & 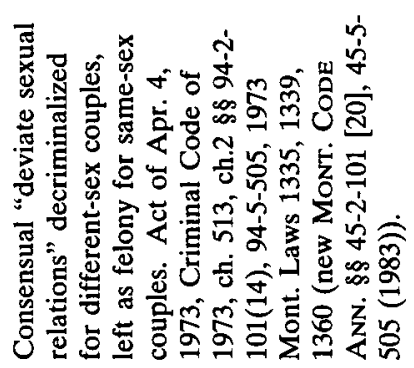 & 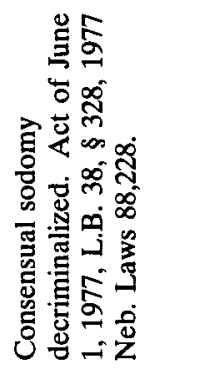 \\
\hline 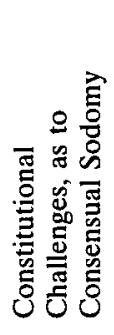 & 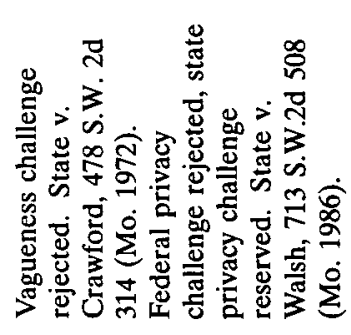 & 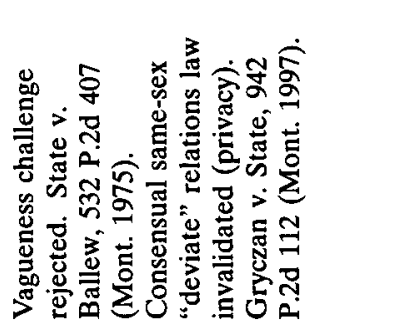 & 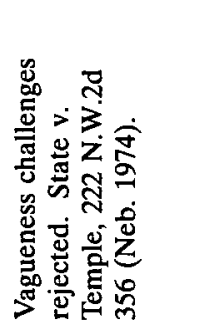 \\
\hline 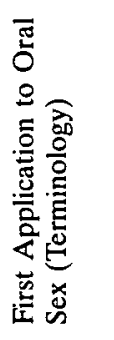 & 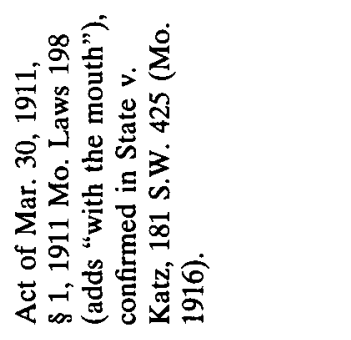 &  & 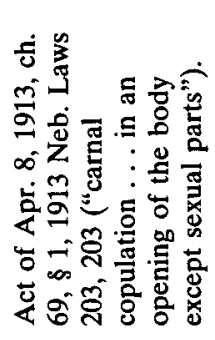 \\
\hline 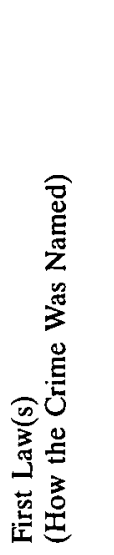 & 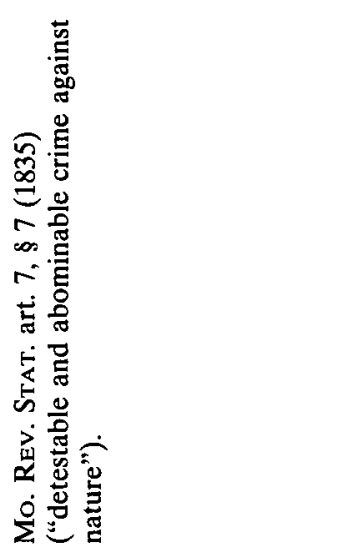 & 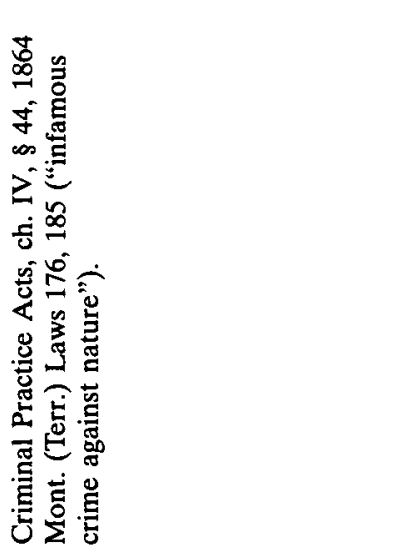 & 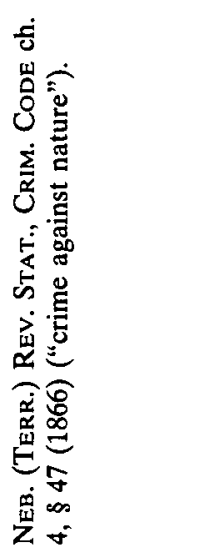 \\
\hline$=$ & $\begin{array}{l}\text { 돜 } \\
0 \\
\text { 怘 } \\
\sum\end{array}$ & 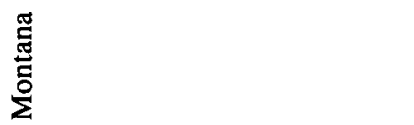 & 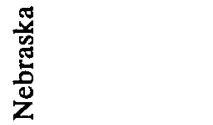 \\
\hline
\end{tabular}




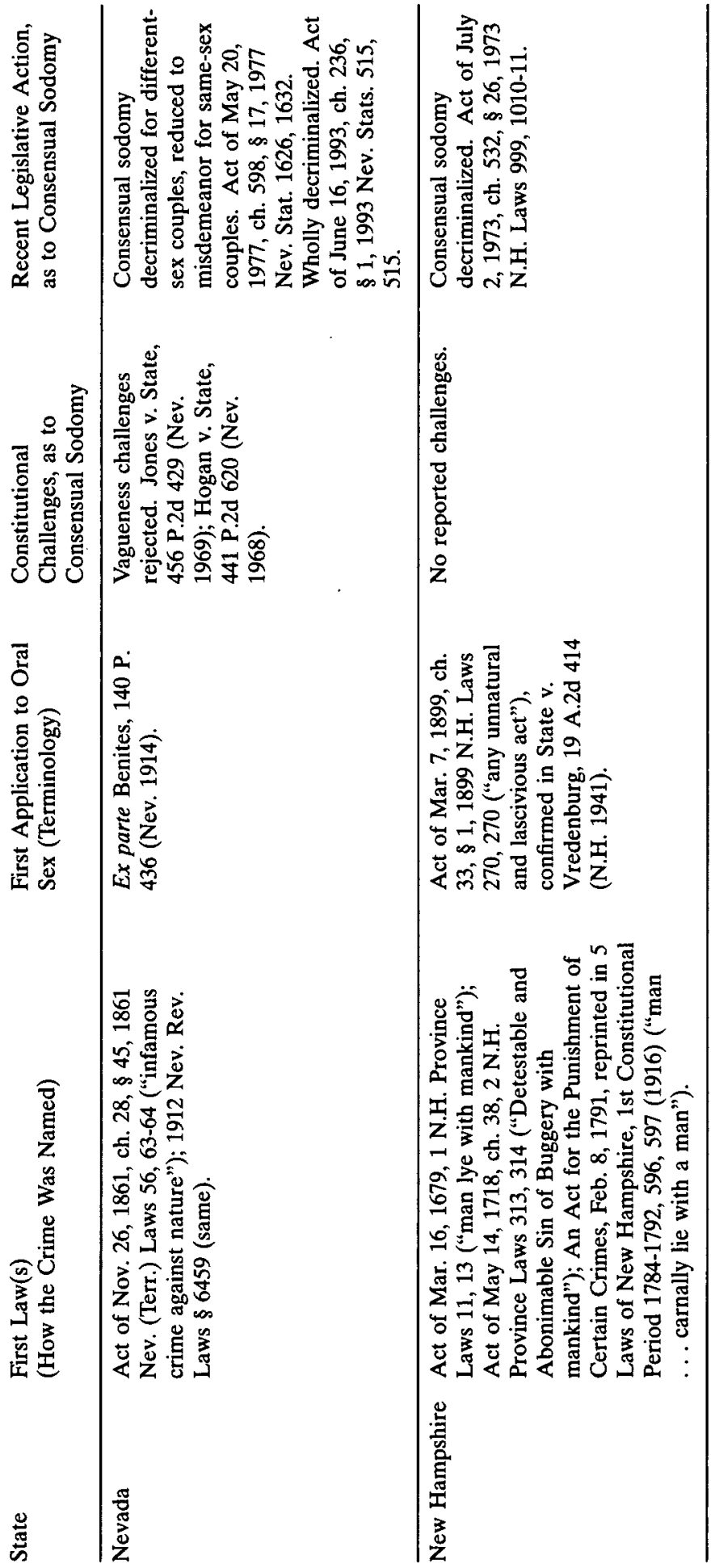



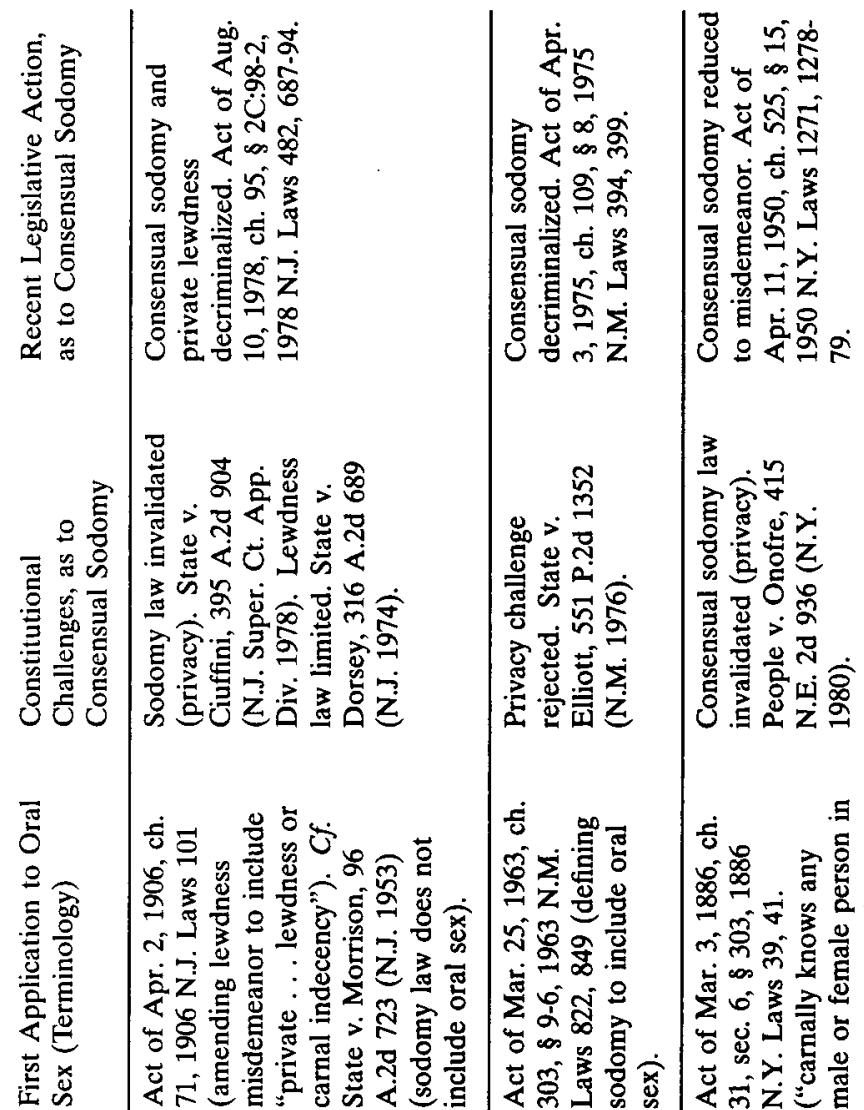

ปั่ $\stackrel{\Xi}{\circ}$

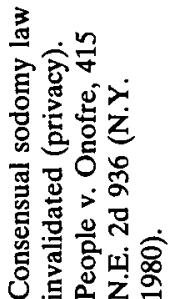

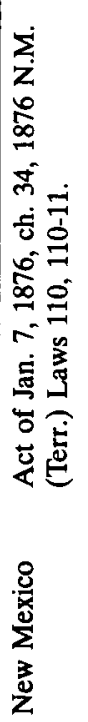

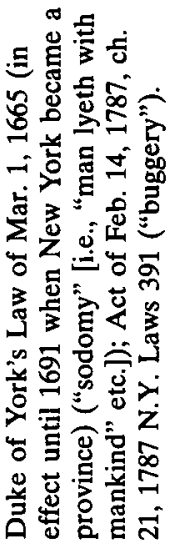




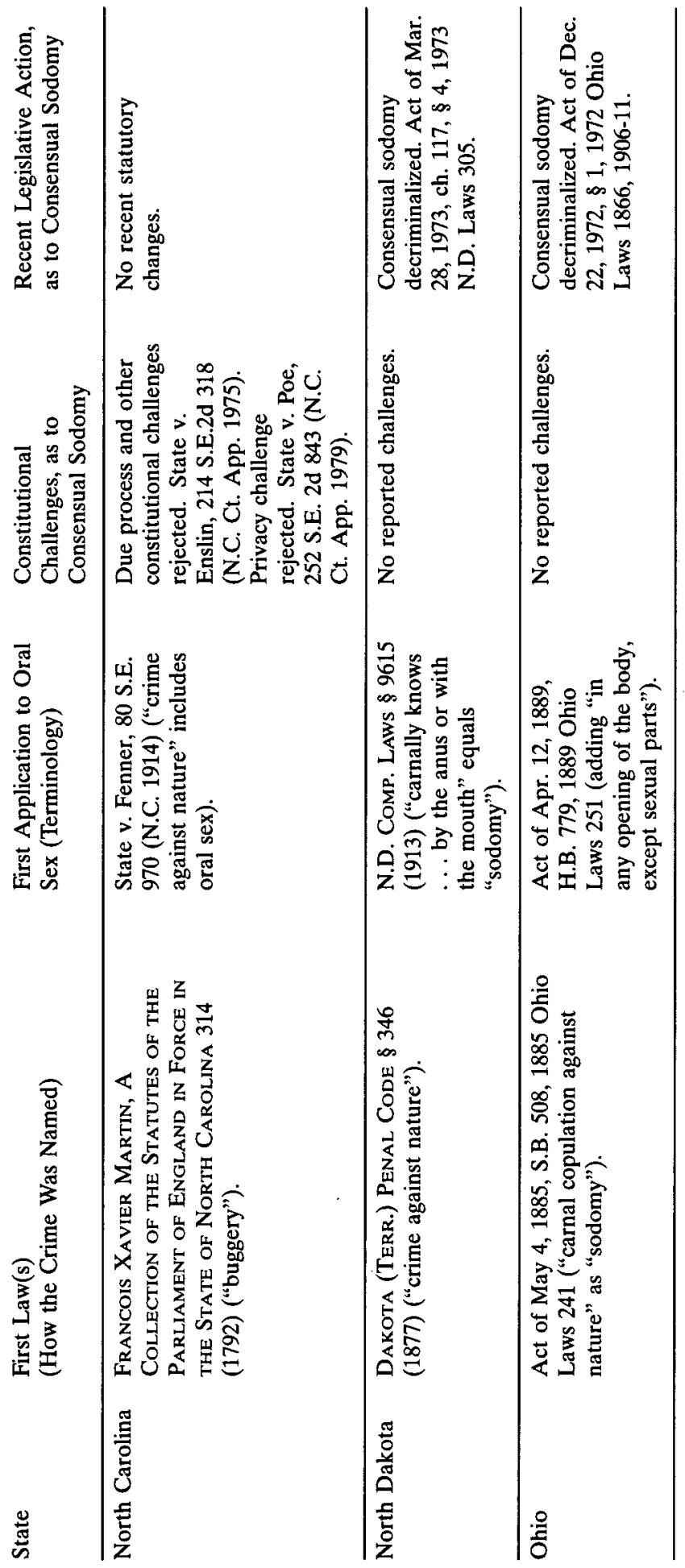




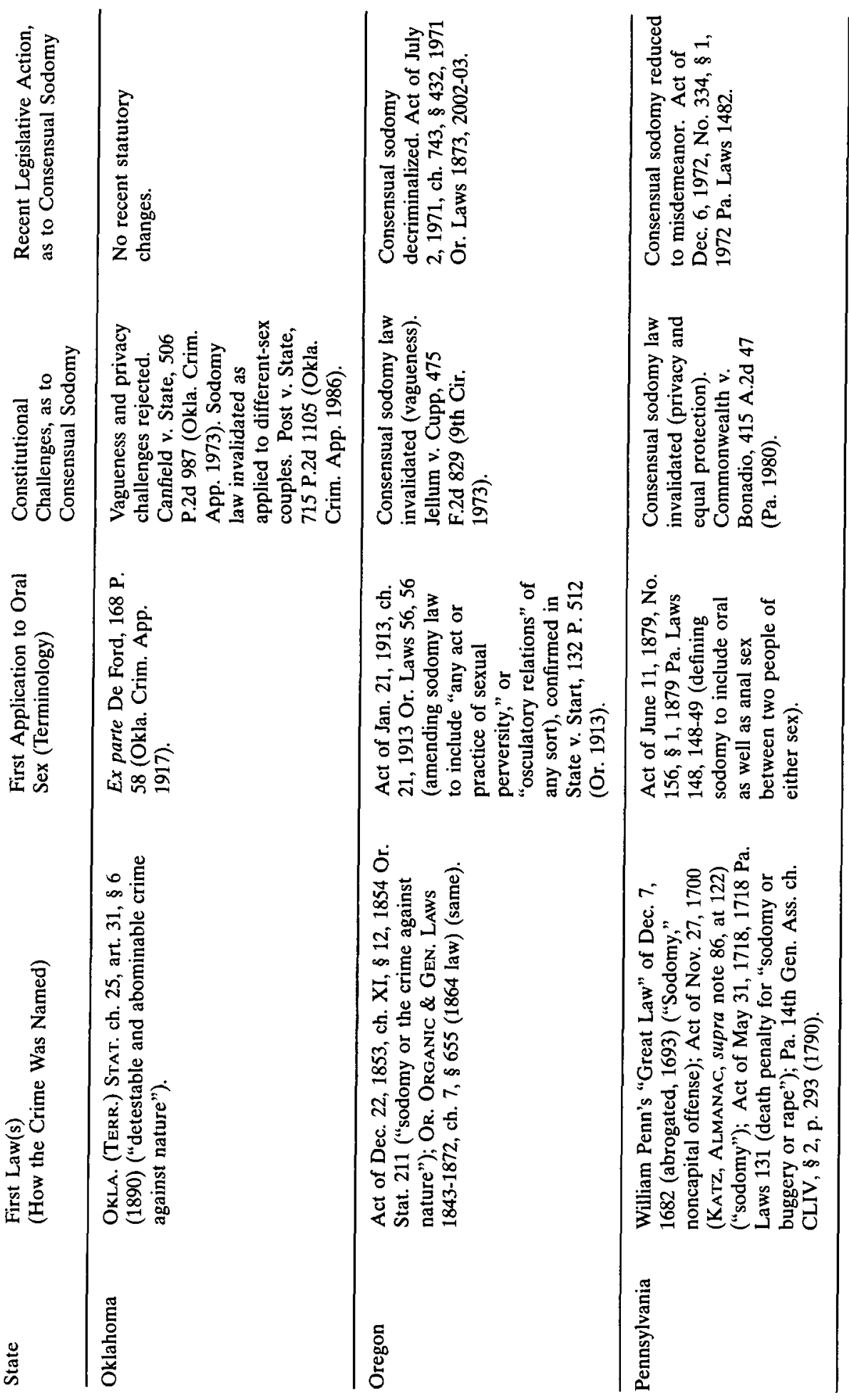




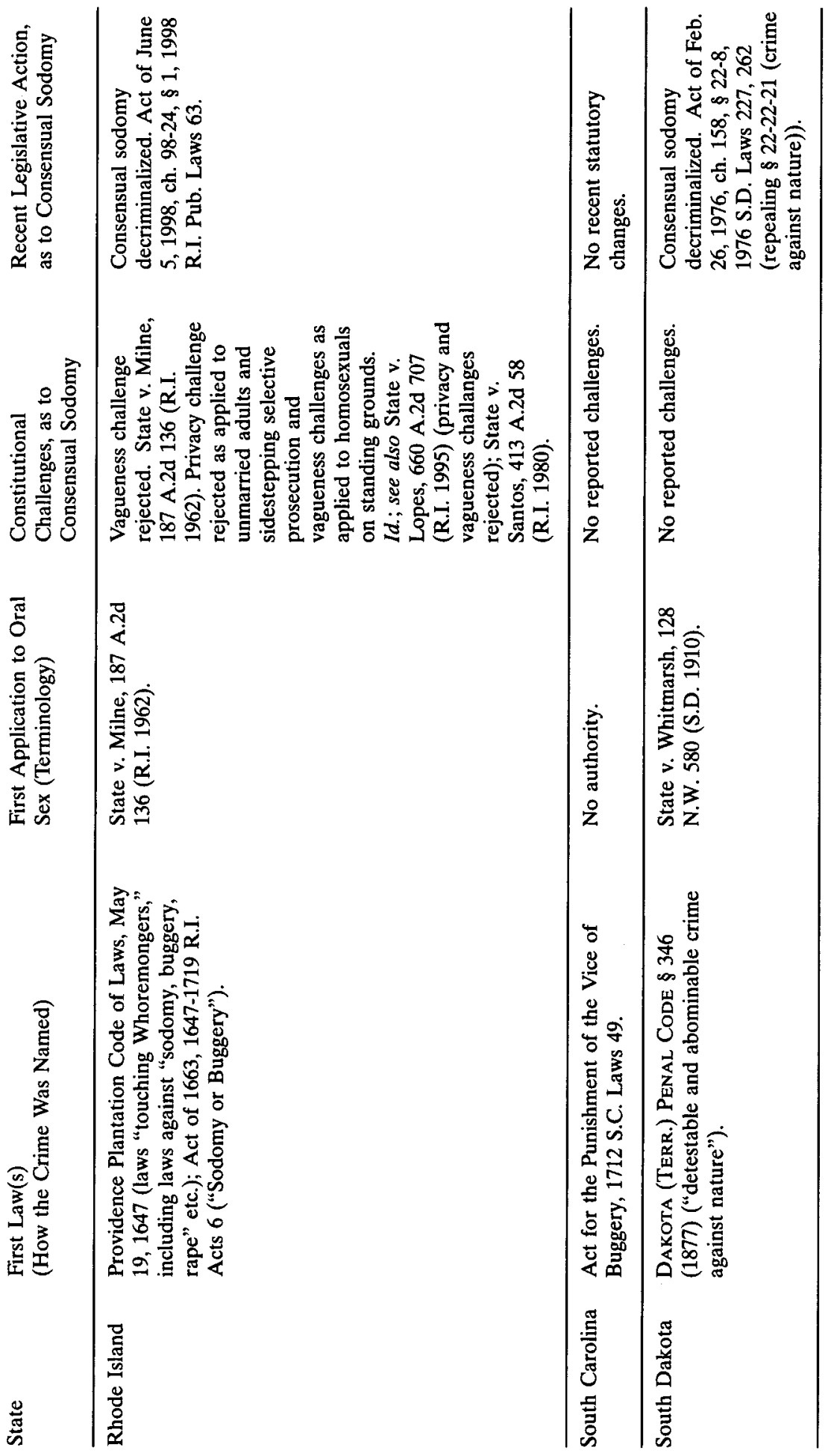



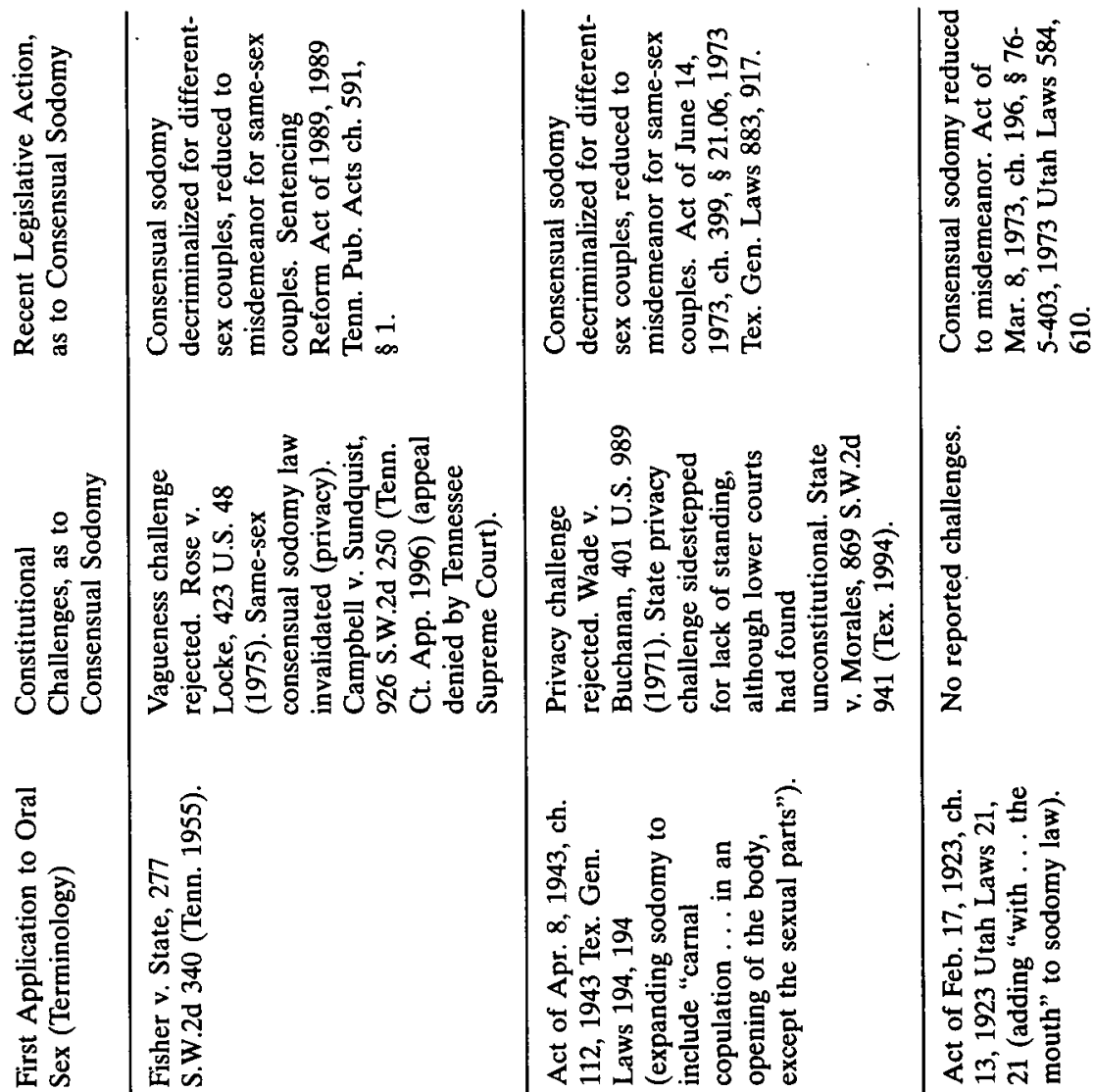

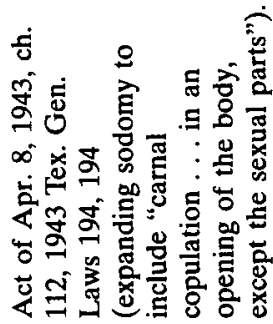

덩

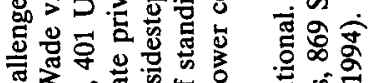

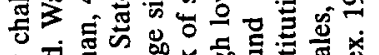

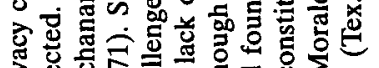

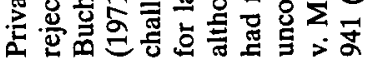

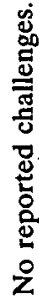

รू:

至承

ن용

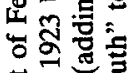

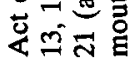

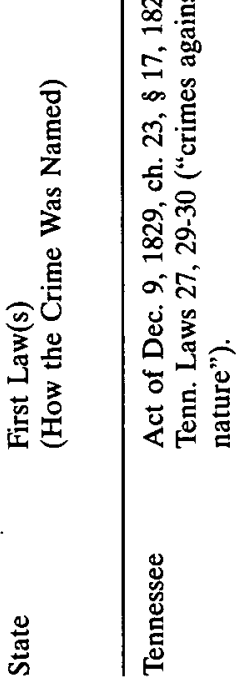

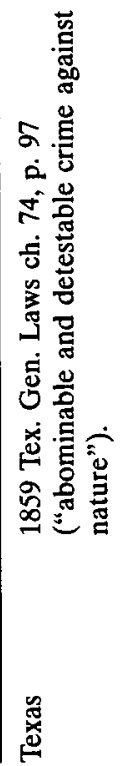

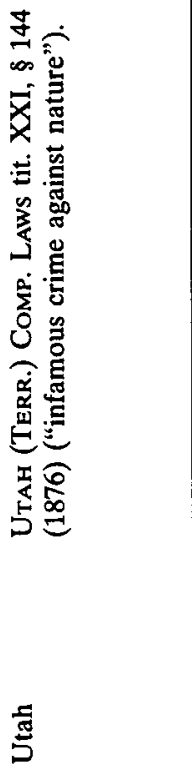


政


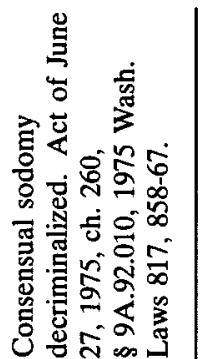

$\sum^{\dot{6}}$

릉

范然学壱

점

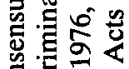

过导

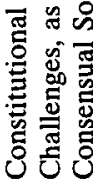

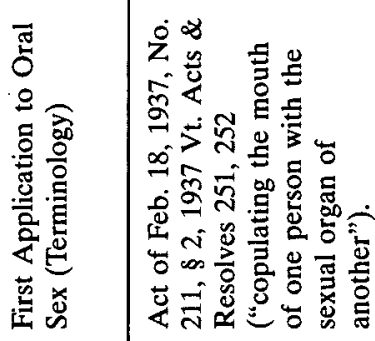

यล

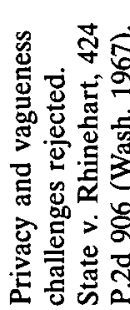

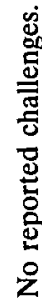

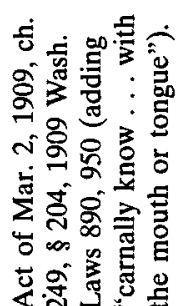

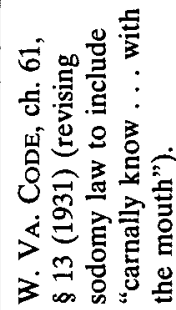

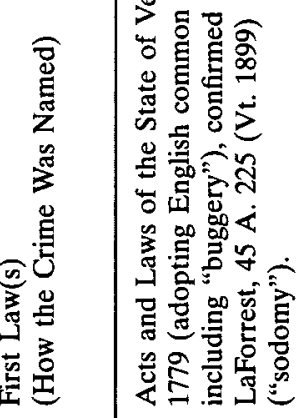

돈

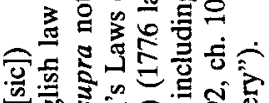

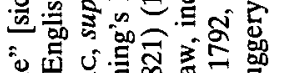

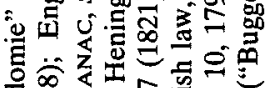

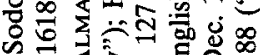

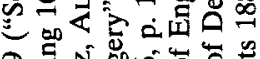

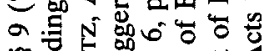

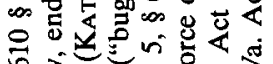

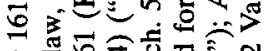

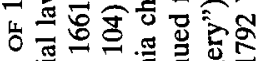

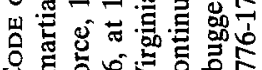

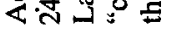

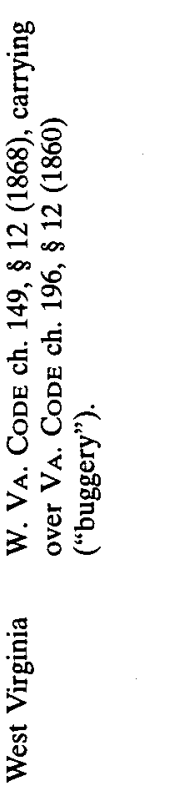




\begin{tabular}{|c|c|c|}
\hline 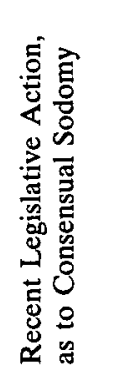 & 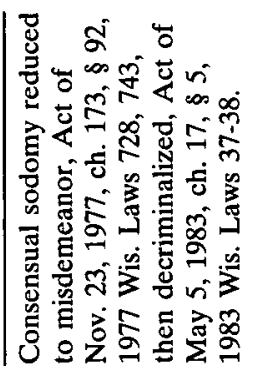 & 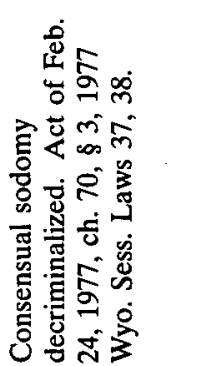 \\
\hline 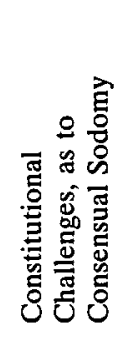 & 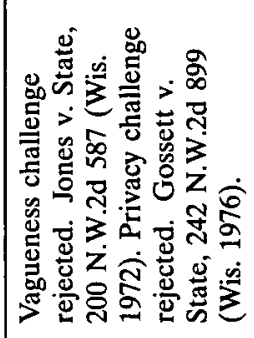 & 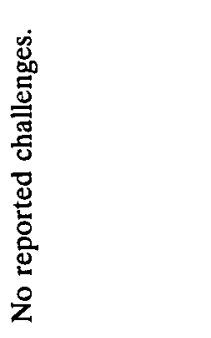 \\
\hline 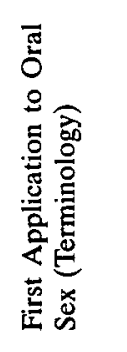 & 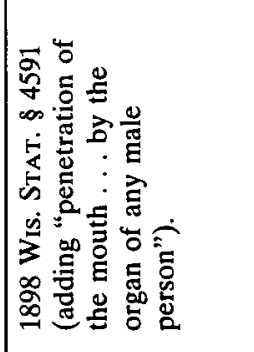 & 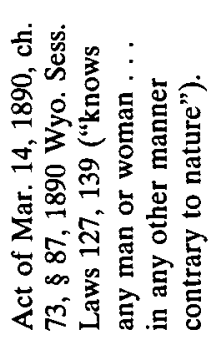 \\
\hline 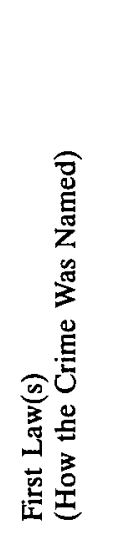 & 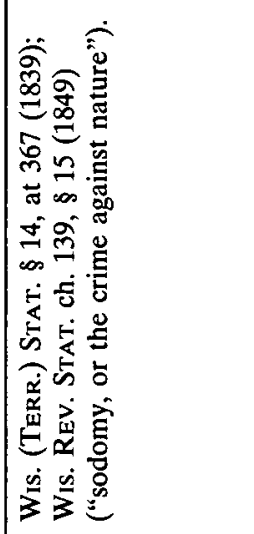 & 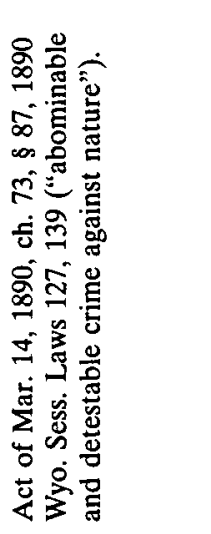 \\
\hline 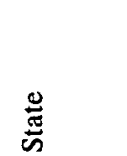 & 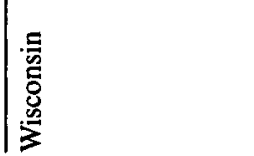 & 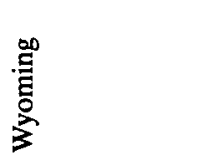 \\
\hline
\end{tabular}

